\title{
Fiscal Federalism and Decentralization in India*
}

\author{
Nirvikar Singh ${ }^{\dagger}$ \\ Department of Economics \\ University of California, Santa Cruz
}

January 2007

\begin{abstract}
This paper surveys the state of fiscal federalism in India, in the broader context of decentralization. We begin with an overview of the basic features and recent developments in intergovernmental fiscal relations, including the role of political institutions, the specifics of legislative and budgetary autonomy, assignments of expenditure responsibility and revenue authority, revenue collection mechanisms, the system of intergovernmental transfers, and institutions and mechanisms for borrowing by subnational units. We then provide a diagnosis of accountability mechanisms, examining their quality of functioning and distortions and constraints. In particular, we analyze to what extent, and through what mechanisms, lower-level governments are held accountable to higher-level governments, the extent to which policies of subnational governments are affected by the competition for mobile firms, taxpayers, and investment capital, the functioning of credit markets, including the responsiveness of subnational governments to credit ratings and bond yields, and the role of democratic electoral channels at national and subnational levels in providing accountability in the provision of subnational public goods. Next, we review the implications of the intergovernmental system and accountability mechanisms on the cooperation of subnational governments and the quality of service delivery. We examine the resources and capacity of the subnational entities that are responsible for key services such as water, sanitation, education and health care, and the impacts of decentralization on service quality and the distribution of benefits among elected officials, citizens and interest groups. Finally, we offer a concluding assessment with suggestions for reform priorities.
\end{abstract}

JEL codes: P26, P35, H1, H7

Keywords: federalism, decentralization, intergovernmental relations, economic reform, accountability, service delivery

\footnotetext{
* This paper has been prepared for a World Bank project assessing the impacts of subnational decentralization. It draws in part on my previous research, particularly coauthored work with $\mathrm{M}$. Govinda Rao and T.N. Srinivasan. I am grateful to them both for the insights they have provided me in our collaborations. I am indebted to Jonathan Rodden for his guidance on the conceptual framework, and his perceptive comments on an earlier draft. None of them, nor the World Bank or affiliated institutions is responsible for any errors or omissions, or the judgments and opinions expressed here. Please do not quote or cite without permission.

$\dagger$ Contact information: Email, boxjenk@ucsc.edu; Phone, 831-459-4093.
} 


\section{Overview of Intergovernmental Fiscal Relations}

India is a large, heterogeneous and complex nation, with multiple languages, religions and ethnicities, and over one billion people. In some respects, it stands out in its political structures, having sustained a working democracy for over five decades at relatively low levels of income. It also is distinguished by its institutional richness and the relative stability of these institutions (Kapur, 2005). Intergovernmental fiscal relations in India must be understood in the context of this broader perspective.

\subsection{Political institutions}

India became an independent democratic nation in August 1947 and a constitutional republic in January 1950. The constitution explicitly incorporated a federal structure, with states as subnational entities that were assigned specified political and fiscal authorities. However, these states were not treated as independent sovereigns voluntarily joining a federation. Thus, for example, the princely states that existed at the time of independence, under the umbrella of British rule, were rapidly absorbed and consolidated into the new political structure, with their special status greatly attenuated, and ultimately (by 1970) totally removed. Also, the states' boundaries were not inviolate, but have been repeatedly redrawn by unilateral central action, as allowed by the constitution. India is now comprised of 28 states, six "Union Territories" (UTs) and a National Capital Territory (NCT), Delhi. In general, the constitution was structured to give the central government residual authority and considerable sovereign discretion over the states, creating a relatively centralized federation.

The primary expression of statutory constitutional authority in India comes through directly elected parliamentary-style governments at the national and state levels, as well as nascent directly elected government bodies at various local levels. The national parliament has two chambers, one (the Lok Sabha or peoples' assembly) directly elected in single member, first-past-the post constituencies, the other (the Rajya Sabha, or states' council) indirectly elected by state legislators. The Prime Minister and council of ministers serve as the executive branch, rather than the largely ceremonial President of the republic. The states, plus the NCT and the UT of Pondicherry, mostly have singlechamber, directly-elected legislatures, with Chief Ministers in the executive role. ${ }^{1}$ The other UTs are governed directly by appointees of the central government. Each state also has a Governor, nominally appointed by the President, but effectively an agent of the Prime Minister. Overlapping political authorities at the central and state levels have been dealt with through intra-party bargaining, and, more recently, through explicit bargaining and discussion. The Inter-State Council (ISC) was created in 1990, and has become a forum where some political and economic issues of joint concern can be collectively discussed and possibly resolved. ${ }^{2}$

\footnotetext{
${ }^{1}$ Initially, all the states had bicameral legislatures, with indirectly elected Legislative Councils (LCs) in addition to Legislative Assemblies but over time, most chose to abolish the former. Currently, five states (Bihar, Jammu and Kashmir, Karnataka, Maharashtra and Uttar Pradesh) still have LCs.

2 The ISC includes the Prime Minister, state Chief Ministers, and several central cabinet ministers as members. While the ISC is merely advisory, it has formalized collective discussion and approval of several
} 
Concentration of powers in the hands of the central government did not create serious conflicts in the early years of the functioning of the constitution since the same political party, the Indian National Congress (INC), ruled at the center and in the states. Many potential interstate or center-state conflicts were resolved within the party. The INC was essentially an umbrella organization that had pursued a campaign of independence from colonial rule, and this nationalist history contributed to its initial nearmonopoly of political power. Over time, the nationalist coalition eroded, with opposition emerging on both sides of the political spectrum. When the INC began to lose power in some states, political and constitutional conflicts became more open. The states, which are, by history and by construction, relatively linguistically and culturally homogeneous did exert pressure in some cases (for example in redrawing state boundaries). ${ }^{3}$ Periodic attempts at reexamining center-state relations through various commissions did lead to some innovations (e.g., the creation of the ISC), but not to any fundamental constitutional changes in the federal balance. However, there was a somewhat natural rise of regional parties in the states, a process that began relatively early in India's post-independence history, but accelerated in the 1980s and 1990s. These regional parties, in addition to dominating subnational politics in several states, have also come to hold the balance of power in coalitions at the national level. Economic reforms that began in the same decades paralleled and accentuated this process of political decentralization.

India's relative political centralization was also reflected in bureaucratic and judicial institutions. The national Indian bureaucracy is provided constitutional recognition. There are also provisions for independent bureaucracies in each state. However, the key component of the bureaucracy is the Indian Administrative Service (IAS), whose members are chosen by a centralized process and trained together. They are initially assigned to particular states, and may serve varying proportions of their careers at the state and national levels. There are varying views on the effectiveness of the bureaucracy, with increasing concerns about competence and corruption leading to active consideration of civil service reform. However, bureaucratic functioning in India is relatively transparent and rule-bound, though the traditional economic policy approach vested the bureaucracy with considerable discretion in such matters. ${ }^{4}$

The judiciary is a constitutionally distinct branch of government at both national and state levels, though the legislative/executive branch exerts influence through appointments and budget allocations. At the local level, IAS members are vested with some judicial authority. The Supreme Court, at the top of the judicial hierarchy, has powers that include broad original and appellate jurisdiction and the right to rule on the constitutionality of laws passed by Parliament. There has been conflict between the Supreme Court and the legislature/executive over the scope of these powers, but in specific issues of center-state relations concerning taxation and property rights, the basic

important matters impinging on India's federal arrangements, including tax sharing and inter-state water disputes.

${ }^{3}$ Regional groupings also have led to several UTs on the periphery of the country becoming full-fledged states, and to the recent splitting of three large states.

4 See Singh (2004) for a review of some of these issues. 
centralizing features of the constitution tilted the Court's interpretation towards the center. In the 1990s, it did make decisions checking the center's ability to override subnational political authority by means such as dismissing state legislatures. Recently, the Court has also tended to engage in some forms of judicial activism in enforcing laws, even at the local level. At the state level, below the Supreme Court, the High Courts superintend the work of all courts within the state, including district and other subordinate courts.

\section{Box 1: Institutions of Local Government}

There are three tiers of rural local government, village group, block and district. Various names are used for these levels in different states, and there is also variation in size and scope. The population per village group is only about 3,000 . Populations per block council are considerably larger, with an average of just over 100,000. The block level approximates the constituencies of the state legislatures. Populations per district council, the highest rural level, are about 1.5 million. The district is approximately the size of the constituency of the member of the Lok Sabha. The have been important components of the administrative apparatus, even prior to independence. Considerable administrative control at the block and district levels has rested with IAS officials. These two levels have also been important in conceptualizing the implementation of India's central plans, and strengthening block-level implementation was a significant part of past attempts to decentralize the planning process.

Urban government types range from corporations to municipalities, and then town and notified area committees. Corporations have more autonomy and wider responsibilities than municipalities, with town and notified area committees being most restricted. Before the constitutional amendments, a difference between notified or town area committees on the one hand, and municipalities and corporations on the other, was that the former had no elected governing bodies: committees were appointed by state governments. Since elected municipalities and corporations were often superseded or overawed by municipal commissioners (typically IAS members), the distinction was less important in practice.

Under the new laws, direct elections to all local governments must be held every five years. Elections to constitute new bodies must be completed before the term expires. If a local government is dissolved prematurely, elections must be compulsorily held within six months, the new body to serve out the remainder of the five-year term. Various aspects of the elections are also specified.

Chairpersons at the intermediate and district rural levels are to be elected by the village council membership, while either direct or indirect elections of chairpersons are permitted at the village level. State level election commissions were created to supervise and manage the electoral processes. At the intermediate and district levels, chairpersons of bodies one level below can be made members, as can MPs (Members of Parliament), MLAs (Members of Legislative Assemblies) and MLCs (Members of Legislative Councils). While the legislation did not conceive of the three levels as hierarchical, these features made hierarchy typical. There is one additional avenue of representation and accountability of local government. Each village group has a gram sabha, a body comprising all registered voters in the area. Gram sabha meetings act as village assemblies, to vote on local matters put to them, hence providing some degree of direct democracy if such meetings are called and used effectively.

Within larger urban governments, wards and zones, with their own committees, are new tiers. Members at the ward and municipal level are now chosen by direct elections. Zonal committees are composed of chairpersons of the ward committees in each zone.

A potentially major change in political institutions was initiated in 1993 when, after decades of debate on decentralization, two constitutional amendments (the $73^{\text {rd }}$ and $74^{\text {th }}$ ) gave firmer legal recognition, enhanced political status, and potentially greater expenditure responsibilities to urban and rural local governments. The amendments reduced state governments' discretionary control over elections to rural local government bodies. Direct elections to local bodies must now be held every five years, potentially 
replacing "hierarchy" with "voice" (Hirschman, 1970; Bird, Litvack and Seddon, 1999; Rao and Singh, 2003) as a primary accountability mechanism. Box 1 describes the electoral institutions of local government in more detail. Local government reform also changed the nature of tax and expenditure assignments to local governments by specifying their authority and responsibilities more fully, and it instituted a system of formal state-local transfers modeled on one component of the existing center-state system. ${ }^{5}$

The impetus for strengthening local governments was quite different from that which led to national economic reform, but it happened to coincide with the latter process. There were normative goals of promoting greater citizen involvement through decentralization, political considerations at the national level of balancing the power of states that were exerting greater autonomy, and, increasingly salient over time, hopes for improving the quality and effectiveness of public spending by pushing decision-making on local public goods down to the local level. There are serious problems with the new legislation and its implementation, including lack of clarity, mismatch between revenue and expenditure authority, problems of local capacity, poor implementation, and so on. Understanding and solving these problems of subnational decentralization will be critical to improving governance and public service delivery in India. The temporal coincidence of subnational decentralization with national economic reform has created additional challenges, because of the fiscal stress of the states since the 1990s, but also an opportunity for a unified approach to decentralization from center to states to local governments as one avenue for improving government performance.

\subsection{Legislative and budgetary autonomy}

At inception, the Indian constitution clearly laid out the areas of responsibility of the central and state governments, with respect to expenditure authority, revenue raising instruments, and legislation needed to implement either. Expenditure responsibilities are specified in separate Union and State Lists, with a Concurrent List covering areas of joint authority. ${ }^{6}$ Tax powers of these two levels of government are specified in various individual articles. Legislative procedures for each level, particularly with respect to budgets and appropriations, are spelled out in detail in the constitution, and are similar to parliamentary democracies elsewhere, having followed the British model.

Powers of legislation for the center and states follow the responsibilities assigned in the three constitutional lists, but there are several relatively broad "escape clauses" which give the national parliament the ability to override the states' authority in special circumstances. Furthermore, the assignment of legislative powers ignores potential conflicts, such as when international treaties, the signing of which is a central power, affect state subjects. ${ }^{7}$ When conflicts over legislation arise between the center and the

\footnotetext{
5 See Section 1.5 for a discussion of intergovernmental transfers.

6 All residual areas not explicitly mentioned are under the center's authority, adding another centralizing feature to the constitution.

${ }^{7}$ Kapur and Mehta (2006, p. 29) give the example of international trade agreements on agriculture, which is itself in the State List, while international affairs are in the Union list.
} 
states, the Supreme Court is the arbiter, as mentioned in Section 1.1. The framework of the constitution tends to favor central authority in such cases. The power to amend the constitution also resides with the national parliament, with a weak requirement that half or more of the states ratify the amendment for it to take effect.

In general, a consensus view is that the functioning of the national and state level legislatures has been short of reasonable standards, often resulting in poorly framed laws. The situation is almost certainly worse at the state than at the national level, though in practice, states have often followed central models for legislation on a range of issues. Also, the executive at each level has played a dominant role in proposing and framing legislation, often with limited input from the legislators themselves.

The situation with respect to local governments is somewhat distinct from the center-state division of powers. The 1993 amendments which gave a constitutional imprimatur to local governments also had to leave many legislative details to the states, since local government was, and remained in, the State List. Furthermore most local responsibilities are subsets of those in the State List. There is no "Local List" as such, but the constitution now includes separate lists of responsibilities and powers of rural and urban local governments. ${ }^{8}$ The lists of local expenditure areas, though now broader and more explicit than was typical of past practice, still overlap considerably with the State List, so most local responsibilities are, in practice, concurrent responsibilities.

Given the constitutional structure (the disturbance of which would have been effectively vetoed by the states), assignment of tax powers and details of expenditure assignments had to be left to state-level legislation. There has been considerable variation in the nature of the laws passed by the states, though it is fair to state that in general they have provided very little revenue autonomy to local governments, especially rural bodies. Paralleling this constraint, local governments also have little legislative autonomy. This is particularly true for rural governments, though traditional village level committees (panchayats) have a history of acting as quasi-legal arbiters and enforcers through social norms. City governments, of course, do have a well-established tradition of local ordinances. The point is that neither revenue authority nor legislative autonomy has been enhanced significantly to match the political decentralization that was implemented beginning in $1993 .{ }^{9}$

As noted, budgetary procedures for the national and state level legislatures are spelled out in the constitution. Budgeting is the responsibility of national and state-level finance ministries. Bureaucratic support and monitoring are also provided through specialized cadres of the civil service. In particular, members of the Indian Civil Accounts Service (ICAS), under the Expenditure Secretary of the central Finance

\footnotetext{
8 The Union, State and Concurrent Lists are in the Seventh Schedule, whereas the new responsibilities of rural and urban local governments are in the Eleventh and Twelfth Schedules, added through the 1993 amendments. See Section 1.3 for details.

${ }^{9}$ In particular, law and order was conspicuously absent from the new local responsibilities, despite arguments for some decentralization, and previous experiments in this direction in one or two states. See Rao and Singh (2003) for a detailed discussion of this issue.
} 
Ministry, deal with maintaining central government accounts, and there are similar state level cadres. The Indian Audit and Accounts Service (IAAS), under the independent Comptroller and Auditor General of India (CAGI), handles auditing of government accounts at the national and state levels. Finally, the Indian Revenue Service (IRS) is responsible for tax administration at the national level, and there are corresponding state level services. At the national level, accounting procedures are relatively strong, and the system is reasonably good at detecting certain types of malfeasance. However, various kinds of corruption and poor use of funds undoubtedly flourish. In some cases, recommendations of the CAGI for procedural improvements are ignored or buried.

While some problems of poor budgeting and expenditure practice exist in the national government, the difficulties are magnified at the level of the states. Some states are much better than others in terms of their governance traditions, but all of them have come under stress in the 1990s, and budget practices have apparently deteriorated in an environment of heightened political competition, greater uncertainty, relaxation of hierarchical controls, and new complexities of governance. Lack of budgetary autonomy, exacerbated by some of the long-standing problems with intergovernmental fiscal relations (dealt with in subsequent sections of this paper) also contributes to the states' poor budgetary practices. Shortcomings in budgetary and expenditure practices include lack of multi-year budgeting, unrealistic projections, poor tracking of spending and outcomes, unclear assignment of responsibilities among different state government departments and agencies, lack of transparency, and inappropriate degrees of control too loose in some parts of the process, too tight in others (International Monetary Fund, 2003, Chapter 4, World Bank, 2005, Chapter 2).

The intergovernmental transfer system involves multiple channels of funding, some ad hoc and discretionary, and others implicit (i.e., subsidized loans and others that will very probably be forgiven), and has aspects that respond to states' projected revenue gaps. These features encourage unrealistic budgeting to try and enhance transfers, and make clear budgeting and proper tracking of spending and outcomes difficult. In particular, so-called "plan transfers," and central ministry transfers for numerous and varied projects and programs can include all kinds of conditionalities that distort statelevel decision-making, and cut across functional departmental authorities. At the same time, the complexity and poor implementation of these "schemes" undercuts any fulfillment of national-level objectives such as correcting for externalities or spillovers. In sum, state level budgetary autonomy is sacrificed without any clear compensating welfare gain. ${ }^{10}$

The budgetary autonomy of local, particularly rural, governments is much more limited than that of the states. There are two dimensions of autonomy, having to do with overall funds, and effective control over those funds. One is the per capita total revenue of local bodies, or its proportion to state revenue. This can measure how much funding the local government has to work with, and how decentralized the system is. An

10 The obvious question arises as to why such an inefficient system persists. Clearly, many of the features described favor certain groups that are able to capture government funds in the system as it functions. The existence of these groups of beneficiaries must be addressed in any consideration of reform proposals. 
alternative aspect of autonomy is the amount or proportion of local revenue that is raised from own sources, rather than being in the form of transfers of some kind. These measures can give quite different pictures. For example, in the period 1995-98, rural local bodies in Karnataka ostensibly had about 50 percent of state revenues, but only about 1 percent of this was from their own sources. In contrast, Haryana's rural governments' revenues were only 1.7 percent of state revenues, but almost 62 percent was from their own sources. ${ }^{11}$ Per capita total revenue was somewhat higher in Karnataka (Rs. 69 versus Rs. 47 for Haryana), but clearly such a comparison would miss the degree to which the spending by rural local bodies in Karnataka was constrained by the external source of its funds (World Bank, 2004a, Chapter II). There was considerable variation among the states, as illustrated by the above comparison, but the averages were extremely low. According to calculations by Chaudhuri (2003), for the 14 major states in this period, own revenues were just 3.7 percent of total revenues, and total revenues were just 14.5 percent of state revenues, over 1995-98. By 2002-03, there had been some improvement in some of the states. For example, Maharashtra's rural local governments raised over 8 percent of their total revenue themselves in that year, versus about 3 percent in the 1990s. Their share of state revenue also went up. ${ }^{12}$ In the case of Madhya Pradesh, per capita revenue went up only slightly, but the proportion of own revenue increased from about 4 percent in 1995-98 to just over 35 percent. In other states, such as Karnataka, there was little difference in the proportion of own revenue, but a significant increase in devolution, and hence total rural local revenues.

If one can summarize and generalize with respect to the somewhat heterogeneous state of rural local finances and budgetary autonomy, the key points are that both in terms of per capita own revenues and total revenues, rural local governments remain severely constrained. The assignment of revenue sources is very limited, in most cases much more than the spirit of the constitutional amendment might have suggested. Funds that flow from state governments not only come with strings attached, but they are disbursed in an uneven and uncertain manner, and sometimes fail to come through when promised. Some of these budgetary management problems flow from lack of willingness on the part of state government actors, and others from lack of capacity (both fiscal and human) on the part of state government bureaucracies (World Bank, 2000, 2004a, 2004b; Finance Commission, 2004). A further problem has been the lack of capacity at the local level. The depth of this problem (compounded by lack of positive efforts at the state government level) is illustrated by the fact that grants made by the Eleventh Finance Commission to improve the databases and accounts of local bodies (urban and rural) remained 70 percent unutilized when the next commission examined the situation almost five years later (Finance Commission, 2004, paragraph 8.43).

\footnotetext{
11 These and other figures for this period are taken from Chaudhuri (2003), and calculated from data in the report of the Eleventh Finance Commission.

12 These estimates are based on the author's calculations from the report of the Twelfth Finance Commission (2004, Annexure 8). The figures reported there for the rural local share in state revenues are for own revenues, rather than total revenues as in Chaudhuri (2003), but the point is still valid, that both dimensions of autonomy "improved."
} 
While urban local bodies share some of the capacity problems of rural governments, they are in somewhat better shape with respect to revenue assignments. Historically, they have had access to property taxes, and the share of own revenue in their total revenue has been much higher than for rural governments. This is unsurprising, since urban economies are greater generators of wealth, and have more sophisticated institutions in general. However, property tax collections have been deteriorating significantly in urban India for decades (Rao and Singh, 2003), and that trend is only now being reversed in some cities (World Bank, 2004b). Arguably, while cities and towns had tax assignments that gave them the potential to raise significant revenue, the political economy of their dependence on state government administration and marginal funding eroded incentives to raise own revenues and spend all revenues effectively. ${ }^{13}$ Thus, even though the proportion of own revenues of urban local governments is much higher than for rural governments, their budgetary autonomy has been similarly limited. In some cases, local governments allowed the property tax to erode as a revenue source because they were able to collect "octroi," a local entry tax on goods. Since octroi is both theoretically inefficient, and subject to high implementation costs and corruption in practice, some states have abolished it (or replaced it with state-level entry taxes), which put pressure on urban governments in those cases. In cases where octroi still is used, replacing it with a more effective property tax remains a priority, albeit a difficult task.

Despite the emphasis in the discussion above on the constraints on budgetary autonomy that local governments face, with funds that are limited in amount and restricted in use, their increased political status and access to formal intergovernmental transfers do represent an increase in autonomy over the pre-1993 situation. The new status of local governments in India, as a result of de jure decentralization, has served to expose some of the longstanding problems that existed with respect to their functioning, both in terms of revenue collection and spending. ${ }^{14}$ This greater transparency should be stressed, rather than just transitional difficulties with meeting new expectations in local government service delivery. In the case of state governments, the de facto decentralization that took place in the 1990s had a different set of impacts. Earlier formal and informal hierarchical control mechanisms eroded in their effectiveness, and the states' fiscal situations deteriorated significantly in that decade.

The response to the severe deterioration of the states' fiscal positions was in various attempts to create new budgetary control mechanisms and institutions. Previous mechanisms had included intra-party bargaining, borrowing controls enforced by the central bank (the Reserve Bank of India, or RBI), and bureaucratic traditions. The first

\footnotetext{
${ }^{13}$ In a parallel fashion, state governments typically not only failed to delegate rural property or land taxes to local governments, but allowed them to almost disappear as a source of state level revenue. In both cases, the visibility of the property tax makes it politically less attractive than indirect taxes such as sales taxes. Rural landowners and urban middle class homeowners may also be effective interest groups. The failure to spend tax money effectively is perhaps the root cause of this political difficulty (Rao and Singh, 2003).

${ }^{14}$ A vestige of the old system is the practice of state governments making ad hoc advances to local governments to cover deficits, and then intercepting transfers to recover these advances. This practice adversely affects transparency, incentives and general budgeting and accounting processes (World Bank, 2004b).
} 
and third of these began to erode even before the 1990s, while the RBI's oversight became less effective with general economic liberalization which gave state governments more freedom of action. This liberalization took place, as noted earlier, in an environment of enhanced political competition at the state level. All of these resulted in state government actions that led to substantial subnational fiscal deficits, and increased borrowing by the states.

Initial attempts by the center to impose conditions on state borrowing that would encourage fiscal reforms, were relatively unsuccessful. For example, in 1999-2000, eleven states signed Memoranda of Understanding (MOUs) with the center, promising fiscal reforms in exchange for ways and means advances (essentially, overdrafts) on tax devolution and grants due to them. In some cases, however, the center had to convert these advances into three-year loans. The RBI reported stopping payments to three states (Reserve Bank of India, 2001), but the political difficulty of not bailing out states that are both poor and populous is obvious. Essentially, this approach was temporary and limited in nature, and therefore lacked credibility of commitment.

In a different approach, the Eleventh Finance Commission tried to build incentives for fiscal reform into the transfer system, but the manner in which these incentives were structured left them too weak to make a difference to state expenditure and borrowing decisions. The pool of money that was to be disbursed conditional on fiscal reform was too small to matter, and the criteria were perhaps not simple and clear enough. The lack of an integrated assessment and control of state finances, and the existence of multiple channels of intergovernmental transfers also contributed to the relative failure of this approach.

The alternative that seems to have worked partially is that of commitment to explicit targets through fiscal responsibility legislation. The central government passed its own Fiscal Responsibility and Budget Management (FRBM) act in 2003, laying down specific targets for deficit reduction. Many state governments have followed the center's lead since then. The RBI provided model legislation, and the Twelfth Finance Commission recommended tying debt relief and restructuring for the states to their passage and implementation of FRBM laws, to extend the scope and impact of such laws to all the states. The Twelfth Finance Commission also recommended minimum provisions for state level FRBM laws. While issues remain of enforceability of such laws by sovereign governments, or by subnational governments that can count on being bailed out, this legislation gets closer to making explicit and credible commitments.

Initial assessments of the impact of the state FRBM laws are quite positive (e.g., Howes, 2004). The laws, though not a necessary route to fiscal consolidation, have had a positive effect on states' fiscal positions. ${ }^{15}$ The advantages of the FRBM route include greater transparency, targeting, and monitoring that can together support better overall governance. Expenditure quality targets (at least constraining expenditure on salaries)

\footnotetext{
15 One can conjecture that such laws, especially without sanctions for failing to meet targets, are a symptom or symbol of a political consensus with respect to fiscal consolidation, rather than an exogenous constraining factor.
} 
have been incorporated in FRBM laws. Institutions for effective monitoring still need to be developed, however. Options include a new independent scorekeeping body (Hausmann and Purfield, 2004), a strengthened Finance Commission (Singh and Srinivasan, 2005a), or the ISC acting as a Fiscal Review Council (Singh and Srinivasan, 2006).

\subsection{Expenditure responsibility}

The Indian Constitution, in its Seventh Schedule, assigns the powers and functions of the center and the states. The schedule specifies the exclusive powers of the center (the Union list) and the states (the State list), and those under joint jurisdiction (the Concurrent list). All residuary powers are assigned to the center. Over time, through various amendments, these three lists have been altered in the direction of greater centralization, by expanding some powers in the Union List, and shifting some items from the State to the Concurrent List. The nature of the assignment of expenditure functions (see Table 3) remains fairly typical of federal nations, and broadly fits with economists' theoretical rationale, ${ }^{16}$ though the breadth of the Concurrent List in some cases creates problems of lack of clear responsibility.

The functions of the central government are those required to maintain macroeconomic stability, international trade and relations, and those having implications for more than one state, state, for reasons of economies of scale and cost-efficient provision of public services. Issuing currency and coinage, dealing in foreign exchange, foreign loans, the operation of the RBI, international trade, banking, insurance, and operation of stock exchanges are some of the major functions assigned to the central government to maintain macroeconomic stability. Functions like the operation of railways, posts and telegraphs, national highways, shipping and navigation on inland waterways, air transport, atomic energy, space, regulation, and development of oilfields and major minerals, interstate trade and commerce, and regulation and development of interstate rivers are the major functions assigned to the center for reasons economies of scale and spillovers in respect of services that have benefits spanning more than one state. The major subjects assigned to the states comprise public order, public health, agriculture, irrigation, land rights, fisheries and industries and minor minerals. The states also assume a significant role for subjects in the Concurrent list, such as education and transportation, social security and social insurance.

As noted earlier, formal guidelines for assignments of local subjects were added to the constitution in 1993, in the Eleventh and Twelfth Schedules (Table 4). Given the structure of the constitution, with local government being a state responsibility, precise assignments were made through individual states' legislations. There was considerable

\footnotetext{
${ }^{16}$ Economic theories of government are based on the idea that public (non-rival and non-exclusive) goods are not well provided by the market mechanism. In addition, if governments are not perfectly informed and intrinsically benevolent, subnational governments may be better able to judge the desired levels of local public goods, and, potentially, can be given more specific electoral incentives to do so than national governments. Spillovers and economies of scale work in the direction of favoring centralized provision of public goods (see, e.g., Olson, 1986).
} 
variation among the states in the extent to which the functions in the two new constitutional schedules were transferred Rao and Singh, 2003; Chaudhuri, 2003), particularly for rural governments. In many cases, states chose to hold back in devolving the full list of functions from the Eleventh Schedule. They also capped village level authority to directly approve expenditures, often at very low levels. In general, even states which devolved significant responsibilities to local governments subsequent to the amendments retained control over the requisite funds (as discussed in the previous and next sections), as well as the bureaucrats or functionaries who would be responsible for implementation. A significant problem with the new local expenditure responsibilities has been the overlapping of the "local lists" with the State List. Combined with the lack of effective decentralization of funds and personnel, this gives the states the ability to overawe local governments completely, if they wish. ${ }^{17}$ Thus, decentralized expenditure responsibilities to local government, while they have been accompanied by some political decentralization, arguably still require decentralization in other dimensions to be effective.

\subsection{Revenue authority and collection}

The initial constitutional assignment of tax powers in India was based on a principle of separation, with tax categories being exclusively assigned either to the center or to the states (Table 5). Most broad-based taxes were assigned to the center, including taxes on income and wealth from non-agricultural sources, corporation tax, taxes on production (excluding those on alcoholic liquors) and customs duty. These were often taxes where the tax revenue potential was greater, as a result of relatively lower collection costs, and higher elasticities with respect to growth. The center was also assigned all residual tax powers.

Initially, the central government followed principles that emphasized extreme progressivity and narrow targeting, resulting in a very inefficient tax structure (with very restrictive import quotas and prohibitively high tariffs being prime examples), and tax administration that was highly susceptible to corruption. Economic reform has led to a substantial rationalization of the central government tax structure, in terms of lowering marginal rates, simplification of the rate structure, and some degree of base broadening. This reform agenda was first laid out in the 1991 report of the tax reform committee headed by Raja Chelliah, and has been further developed in subsequent reports, notably two reports prepared by committees chaired by Vijay Kelkar. In the realm of tax administration, however, despite detailed academic analyses (e.g., Das-Gupta and Mookherjee, 1998) and recommendations by the same committees, less progress has been made, perhaps reflecting general political economy constraints on improving the quality of governance through reducing rent-seeking and corruption.

At the subnational level, a long list of taxes was constitutionally assigned to the states (Table 5), but only the tax on the sale of goods has turned out to be significant for state revenues. This narrow effective tax base is largely a result of political economy

17 To some extent, the small size of most local governments and their weaker constitutional status makes the state-local balance inherently different from that of the center and states. 
factors (e.g., rural landed interests were initially quite powerful in government at the state level) that have eroded or precluded the use of taxes on agricultural land or incomes (and also of user charges for public irrigation and even electricity) by state governments. In addition, the separation of income tax powers between the center and states based on source (agriculture vs. non-agriculture) created avenues for evasion, since the states chose not to tax agricultural income. The greatest inefficiencies arose in indirect taxes. Even though in a legal sense taxes on production (central manufacturing excises) and sale (state sales taxes) are separate, they tax the same base, causing overlapping and cascading, and leaving the states less room to effectively choose indirect tax rates. Also, the states were allowed to levy taxes on the sale and purchase of goods (entry 54 in the State list) but not services. This provided avenues for tax evasion, and delayed the design and implementation of a comprehensive value added tax (VAT). These issues have been a major subject of recent policy and institutional reform initiatives.

One other aspect of the initial assignment of tax powers between the center and states deserves detailed attention, because it addresses an important characteristic of a federal system, namely, an internal common market. The framers of the constitution were aware of the need for a common market, but also included a rather broad escape clause. Article 301 of the Constitution states, "Subject to the other provisions of this part, trade, commerce and intercourse throughout the territory of India shall be free". However, Article 302 empowers Parliament to impose restrictions on this freedom in the "public interest" - a term that is both very broad and not clearly defined in this context.

The most significant fiscal impediment to free inter-state trade has been the manner of levying inter-state sales taxes. In general, sales taxes have been levied by exporting states on the inter-state sale of goods, making the tax origin-based. On the other hand, the constitution's framers intended that the sales tax system in India should be destination based. While there is no clear theoretical argument for choosing one taxation principle over the other, clarity and consistency are virtues, and these were lost in the evolution of sales taxation in India. According to Article 286 of the Constitution, "No law of a state shall impose, or authorise the imposition of the tax on the sale or purchase of goods where such sale or purchase takes place (a) outside the state, or (b) in the course of import of goods into, or export of goods out of, the territory of India." This principle was gutted very early on. Based on the recommendations of a taxation commission in 1953, the Sixth Amendment to the Constitution added clauses that enable the central government to levy taxes on inter-state transactions. Under these new provisions, the central government authorized the states to levy a tax on inter-state sales, subject to a specified ceiling rate (4 percent).

A further problem in tax assignments lies in an inconsistency in constitutional provisions. Although Article 286 does not allow restrictions on inter-state transactions, entry 52 in the State list empowers the States to levy tax on the entry of goods into a local area for consumption, use or sale. In many states, the tax has been assigned to urban local bodies (octroi). In some states, the local entry taxes were eventually replaced by state entry taxes. Thus, taxes are levied not only on the exports from one state to another but also on all imports into local areas, including imports from other states. These entry 
taxes are destination-based, so the problem of inter-state taxation has had another side as well as those created by the amendment to Article 286.

In the case of local governments, the constitutional amendments provided no explicit guidelines for revenue authority. The language of the amendments simply leaves such assignment up to the states, which are supposed to decide which taxes local bodies may levy themselves, and which state-collected taxes are to be assigned to local governments. As we have noted in discussing the budgetary outcomes and autonomy of local governments, rural governments in particular do not seem to have adequate sources of revenue assigned to them, although for both rural and urban governments, the problem is also one of inadequate revenue effort. Even so, revenue authority may be the dimension of decentralization where local governments are most constrained.

Even before the constitutional changes, local governments had a number of taxes assigned to them by individual states. Rural local governments had as many as 27 different taxes (20 exclusive, 7 concurrent with the state government) available to them (Datta, 1992). Exclusive taxes included terminal taxes and octroi; property and building taxes; oil engine, food, timber, fishery and produce taxes; and profession and labor taxes. Concurrent taxes included those on commercial crops and on land. For the lowest rural government level in some states, land revenue was a significant proportion of revenue, though absolute amounts were small in all cases: no rural local tax was a significant source of revenue. Twenty different taxes were available to urban governments, nine exclusively to them and 11 concurrent with state governments. In contrast to rural governments, several of these were significant revenue sources, particularly octroi and property taxes, but also entertainment taxes in some cities. In many cases, even after local government reforms, tax assignments remain unclear, and states do not provide assistance or guidance to local bodies in implementing tax collection.

Turning to non-tax revenue (from user charges and fees), ${ }^{18}$ on average this was less than tax revenue for rural and urban governments, though the ranking was reversed in many states (Twelfth Finance Commission, Annexures 8.8 and 8.9). Poor delivery often creates a situation where the imposition of user charges is politically difficult, because the benefits are not clear to the payers: a low level equilibrium persists (Rao and Singh, 2003). In many cases, unclear or overlapping assignments of expenditure responsibility compound problems of accountability and implementation of fees.

At both the state and local levels, revenue authority falls short of what would allow each level to independently meet its expenditure responsibilities. To some extent, this is a natural outcome of the different driving forces for assigning revenue authority and expenditure responsibility. Most significantly, mobility across jurisdictions increases

\footnotetext{
18 The most common fees are user charges for water and lighting. These are typically collected at the lowest rural level and, in the absence of monitoring ability, are flat fees. On the other hand, charges for sanitation, or for public events such as fairs and festivals, are rarely assigned or employed. Panchayats (village level councils) are usually not empowered to levy user charges on health and education (with some states being exceptions), even though aspects of these functions are assigned to them. User charges in urban areas are often extremely low, not just for goods consumed by the poor, but also services such as land development (Rao and Singh, 2003).
} 
as the size of the jurisdictional unit decreases. A tax base that is mobile may shrink dramatically in response to a tax, making it harder for smaller jurisdictions to raise revenue from taxes. One can think of the problem as being one of tax "capacity": this being lower for states, and still lower for localities. If this factor implies that more taxes should be collected by the center, there will be a tendency for there to be a mismatch between revenues and expenditures for subnational jurisdictions, to the extent that subnational governments are relatively better able to respond to diversity of preferences. ${ }^{19}$ This is certainly true in India, and is dealt with through significant intergovernmental transfers, which are discussed in the next section.

The last dimension of revenues, after statutory assignment and imposition, is collection. Collection of taxes and user charges is relatively poor at all levels of government. Even the mechanisms for collection of charges between governments or government-owned enterprises function poorly, although India has reasonably welldefined institutions and organizational structures for collection (e.g. the IRS, mentioned in Section 1.2. Of course, corruption is a major problem at all levels, so that illegal payments substitute for tax or fee collection. Designing administrative systems to control corruption is not easy, but can be done, following certain conceptual guidelines (DasGupta and Mookherjee, 1998). Actually doing so is an ongoing issue for policy reform. In many cases, the design of tax systems is poor, hindering collection and encouraging corruption, and here progress has been made in areas such as the national income tax and state sales taxes. However, particularly at the state and local levels, design problems remain. Sometimes rates or fees are trivially low, making collection inefficient. In other cases, tax rates are prohibitively high, encouraging corruption. Assessment of tax liabilities is often done poorly, especially for cases such as the property tax (World Bank, 2004b). Exemptions of various kinds narrow tax bases, reduce fairness, decrease allocative efficiency, and also encourage evasion.

Because tax systems and fee schedules are often poorly designed, they make collection more difficult, and this contributes to poor collection rates. For some taxes, such as the urban property tax in some cities, collection rates have been abysmally low, but problems have also existed for national taxes such as the personal income tax. Poor collection rates at the local level are also a reflection of poor accountability, both in delivery of public services that are meant to be funded from these taxes and fees, and in the collection agencies and their political superiors (see Section 2). Poor revenue collection is therefore another aspect of the low level political equilibrium mentioned earlier. Arguably, formal institutions such as the bureaucracy and public enterprises function below their potential in this kind of equilibrium.

\footnotetext{
19 This problem can be avoided to some extent by coordination of taxes among subnational jurisdictions. For example, different states might agree to charge the same minimum sales tax rate or income tax rate. Unlike national taxes, these would only be on state-level tax bases, but the incentive for the activities that are taxed to move to other, less-taxed locations would be reduced. There are enforcement problems in such agreements, since each state might wish to cheat, either directly reneging, or using nontransparent subsidies to compensate for the taxes, say to attract capital to their own jurisdictions. One response to this might be central imposition of this coordination of rates.
} 


\subsection{Intergovernmental transfers}

The realized outcome of the Indian assignments of tax and expenditure authority, their manner of implementation, and the response of different levels of government and taxpayers to the assignment and implementation, has been a substantial vertical fiscal imbalance. In 2004-2005, the states on average raised about 39 percent of combined government revenues, but incurred about 66 percent of expenditures. ${ }^{20}$ Transfers from the center, including tax-sharing, grants and loans made up most of the difference, with the states also borrowing moderately from other sources. Focusing on current expenditure only, states financed about 58 percent of that total from their own sources of revenue in 2004-05, up from 52 percent in 2002-2003, but considerably lower than the ratio that had prevailed in the early days of the federation. In terms of total expenditure (including capital spending), the states covered only about 42 percent by their own revenue receipts in that year. There has always been considerable variation across the states in their transfer dependence, and the ranking is not completely determined by per capita income. For the three years 2000-2003, of the 16 larger states, ${ }^{21}$ the three with the highest ratios of own revenue to revenue expenditure were Haryana (0.78), Maharashtra (0.68) and Tamil Nadu (0.65), while the three with the lowest ratios were Bihar (0.25), West Bengal (0.32) and Orissa (0.34) (Finance Commission, 2004, Annexure 7.10).

As noted in Section 1.2, local governments are even more dependent on transfers from higher levels. In 2002-03, rural local governments' own source revenues were less than 7 percent of their total revenue and less than 10 percent of their current expenditures. Urban local bodies did somewhat better, with proportions closer to those of the states. They raised about 58 percent of their revenue and covered almost 53 percent of their expenditure from own revenue sources. Note that aggregate local government expenditure constituted just about 5 percent of total government spending at all levels.

The large vertical fiscal imbalances between levels of government have not been unanticipated, and constitutional provisions exist to deal with them. These provisions were inserted in the original constitution to cover center-state transfers through the creation and operation of a Finance Commission (FC), and those, in turn, served as a model for State Finance Commissions (SFCs) mandated by the 1993 local government amendments to make state-local transfers. The SFCs were created by individual states, as required by the constitutional structure wherein local government is a state subject. In both cases, however, other channels of transfer exist. Loans will be treated separately in Section 1.6. However, the creation of an apparatus of central planning soon after the constitution was ratified led to a complex system of plan transfers which involve both subnational levels. This planning mechanism is modeled in some ways on the now defunct Soviet system, but has uniquely Indian features of implementation. In addition, and somewhat intertwined with the planning system, are various transfers from central and state government ministries to lower levels. It is convenient to first treat the three

\footnotetext{
20 These figures are constructed from various tables in RBI (2006). Both proportions do vary somewhat from year to year, and have been subject to political cycles. The estimated figures for 2005-06, calculated from the same source, were 38 percent of revenue and 60 percent of expenditure.

${ }^{21}$ This excludes mostly the hill states, which have greater transfer dependence, as well as the small, highincome state of goa.
} 
channels of center-state transfers in turn, and then discuss the various aspects of statelocal transfers together. Data on the composition of center-state transfers is presented in Table 6, in which central ministry transfers are classified under "plan transfers." The rationale for this will be discussed later in this section.

\section{Finance Commission Transfers}

The constitution provided for the sharing of the proceeds of certain centrally levied taxes (e.g., non-corporate income tax, Article 270; and Union excise duty, Article 272) with the states, as well as grants to the states from the Consolidated Fund of India (under Article 275). Recent constitutional changes (the $88^{\text {th }}$ amendment, passed in 2000) in this scheme have simplified this sharing arrangement, replacing it with an overall share of the consolidated fund. The shares of the center and the states, and their allocation among different states are determined by a constitutionally-mandated Finance Commission, which is appointed by the President of India every five years (or earlier if needed). FC transfers are mostly unconditional in nature. The FCs' approach to federal transfers has consisted of (i) assessing overall budgetary requirements of the center and states to determine the resources available for transfer from the center during the period of recommendation, (ii) projecting states' own revenues and non-plan current expenditures, (iii) determining the aggregate and individual states' share of the consolidated fund of the center, and (iv) using grants to fill projected expenditurerevenue gaps remaining after tax devolution.

Twelve FCs have made recommendations to the central government and, with a few exceptions, these have been accepted. The Commissions have developed an elaborate methodology for dealing with horizontal and vertical fiscal imbalances. In particular, the formula for tax devolution is quite complicated, as a result of attempts to capture simultaneously disparate or even contradictory factors (Table 7). The result has been that the impact of FC transfers on horizontal equity (equalizing fiscal capacity across states) has been limited. ${ }^{22}$ Despite the ad hoc nature of the tax-sharing formula, its persistence reflects the nature of precedent that has grown around the $\mathrm{FC}$, even though it is not a permanent body, and lacks continuity in its staffing and its analysis. Grants recommended by the FCs have typically been based on projected gaps between non-plan current expenditures and post-tax devolution revenues. As with tax sharing, these grants have generally been unconditional, although some commissions have attempted to enhance outlays on specified services in the states by making closed-ended specific purpose nonmatching grants. In either case, the incentive problems with this "gap-filling" approach are obvious. Some commissions did try to incorporate normative growth rates of revenues and expenditures in their calculations, but these attempts were selective and later ignored.

\footnotetext{
22 See Rao and Singh (2005) and World Bank (2005). The exception is the so-called 'special category' states. These are hilly states on India's borders, with strategic importance as well as cost disabilities in public good provision. Bagchi and Chakraborty (2003) provide some illustrative calculations of how transfers would need to change to achieve greater horizontal equalization for the major states.
} 


\section{Planning Commission Transfers}

While the FC decides on tax shares and makes grants, a completely separate body, the Planning Commission, makes grants and loans (in the ratio 30:70 for the major states) $^{23}$ for implementing development plans. As development planning gained emphasis, the Planning Commission became a major dispenser of such funds to the states, and it also coordinates central ministry transfers: almost one-third of center-state transfers are made through these channels (Table 6). As there is no specific provision in the Constitution for such plan transfers, the central government channeled them under the miscellaneous (and limited) provisions of Article 282. Before 1969, plan transfers were project-based. Since then, the distribution has been done on the basis of a consensus formula (see Table 8) decided by the National Development Council (NDC). ${ }^{24}$ As in the case of the FC, the Planning Commission formula tries to aggregate disparate objectives in its calculations, with the result that the overall impact is less than clear.

One major contrast with the $\mathrm{FC}$ is the conditional nature of Planning Commission transfers, since they are earmarked for "developmental" purposes. However, while the special category states receive plan transfers based on projects that they formulate and submit, the general category states' plan transfers are not related to the required size or composition of plan investments. Hence there is not even implicit matching of states' own resource commitments in this transfer channel, let alone an explicit matching formula. The process for determining plan transfers involves competing proposals from the Planning Commission and the states, with a certain amount of bargaining through the NDC, as well as in state-by-state discussions, to determine plan loans and grants. At the end of this process, the Planning Commission approves the state plans. The allocation and spending process does appear to distort states' budgeting and expenditure decisions, and not necessarily in ways that are desired by the center or more socially efficient.

\section{Central Ministry Transfers}

Various ministries give grants to their counterparts in the states for specified projects, either wholly funded by the center (central sector projects) or requiring the states to share the cost (centrally sponsored schemes). The ostensible rationale for these programs is financing activities with a high degree of inter-state spillovers, or which are merit goods (e.g., poverty alleviation and family planning), but they are often driven by pork-barrel objectives. These projects are supposed to be monitored by the Planning Commission, and coordinated with the overall state plans - which is why they are listed under Plan transfers as in Table 6 - but both monitoring and coordination are relatively ineffective. There are well over 100 schemes, and attempts to consolidate them into broad sectoral programs have been unsuccessful, though they continue. These programs have provided the central government with an instrument to actively influence states' spending, replacing pre-1969 plan transfers in this role. The proliferation of schemes may also have increased the size and control of the bureaucracy. While the NDC recently

\footnotetext{
${ }^{23}$ The special category states receive a much higher proportion (90 percent) of their Plan fund allocations as grants.

${ }^{24}$ The NDC is chaired by the Prime Minister, and its members include all central cabinet ministers, Chief Ministers of the states, and members of the Planning Commission. Like the ISC, it serves as a bargaining and log-rolling body, though with a much narrower scope.
} 
appointed an investigative committee that recommended scaling down and consolidating centrally sponsored schemes, implementation of this proposal was weak: new proposals have recently been floated with similar objectives. For all channels of center-state transfers, but particularly more discretionary transfers such as ministry grants, there is some evidence (Section 2.4) that political factors influence allocations across states.

\section{State-Local Transfers}

Local government reform instituted a system of formal state-local transfers modeled on the Finance Commission component of the existing center-state system. However, the new SFCs have struggled to formulate the principles for sharing or assigning state taxes, tolls, and fees and for making grants-in-aid. There remains considerable variation in the quality of analysis, methodologies used, and implementation of transfers across the different states. Lack of political will at the state level and, perhaps most significantly, the states' own fiscal problems have restricted progress in this dimension. Some states have been slow to constitute SFCs, and some have been tardy in implementing their recommendations. The outcome has been significant uncertainty, which hampers effective use of funds by local governments. Sometimes, SFC recommendations have been significantly ignored by state governments. Nevertheless, the SFC system has made local government financing more transparent. ${ }^{25}$

While detailed and accurate data on the nature of state-local transfers (especially in terms of the source of the funds and the effective degree of conditionality) remains elusive (Finance Commission, 2004, Chapter 8), ${ }^{26}$ some recent studies have collected such data (World Bank, 2004a) and the FC itself has compiled data provided by state governments. Table 9 reports the percentage composition of local revenues, showing the mix of grants and tax sharing for rural and local governments. The former, in particular, can be seen to rely heavily on grants. These data include FC grants made to augment to consolidated funds of the states, but earmarked for local governments. They also sometimes $^{27}$ include Planning Commission transfers to the states that are then further devolved to local governments. The latter, in particular, are project or program-based categorical grants, but the FC has also included its own earmarks, for example for improving accounting and databases, and for waste management, and the states often add their own conditionalities. As a result, local revenues, particularly for rural governments, include a large component of funds, the spending of which is predetermined by higher level agencies (e.g., Rajaraman, 2001).

As noted, the various SFCs have used a wide range of approaches to allocate funds among local governments under their purview. ${ }^{28}$ To some extent, this is consistent

\footnotetext{
25 In fact, the problems of uncertainty and arbitrariness in state-local fiscal relations are a heritage of the old system of discretionary control, rather than a consequence of reform (Rao and Singh, 2003).

26 In particular, the data does not yet permit an analysis of political economy determinants of state-local transfers, whether with respect to variation across localities or over time. Since data before the reforms is essentially non-existent, one cannot ever examine the impact of reform per se. However, over time, it may be possible to isolate political economy factors in changes in the pattern of stat-local transfers.

27 There is a lack of consistency in accounting and reporting among the states in this respect.

28 See PRIA (2005a) for a recent summary of SFC recommendations across states. The latest FC report (Finance Commission, 2004, Annexure 8.10) summarizes the timing status of individual SFC reports. In
} 
with a philosophy of decentralization: objectives may differ across the states. However, it does not justify the lack of any coherent approach within a state, nor poor quality of analysis (Finance Commission, 2004; PRIA, 2005b). While the FC itself is not immune to methodological criticism, its functioning has been comparatively of a much higher standard, right from the institution's inception. Perhaps the complexity and size of the task facing the SFCs, including the large number of local governments with multiple tiers and great heterogeneity, as well as resistance from state-level politicians and bureaucrats explains the quality difference as much as the novelty of the exercise. The FC itself uses a modification of its basic approach for center-state transfers in making grants to the states that are earmarked for local governments: various criteria are weighted and combined to determine allocations across the states (Table 10).

\subsection{Borrowing by subnational units}

The constitution (Article 293) specifies borrowing rules for state governments. States cannot borrow abroad, and they require central government approval for domestic borrowing whenever they are in debt to the center. In fact, that condition has prevailed almost invariably, since the central government was, until fairly recently, the states' main source of lending, and every state is indebted to the center. Currently, central loans make up about 22 percent of the states' debt stock (RBI, 2006b, Appendix Table 36). Operationally, the RBI, as central bank, manages the debt of all levels of government, and, in the past, typically did not allow market borrowing by state governments that were already indebted.

Central loans are made under the supervision of the Planning Commission (PC), and have been tied to PC grants in a fixed proportion. Central loans also include funds from multilateral agencies or other external sources, which are earmarked for specific programs and projects in particular states. After the reforms of the 1990s, states have more freedom to negotiate directly with multilaterals, and the center plays combined roles of approver, guarantor and intermediary. ${ }^{29}$ Finally, there can be ad hoc central loans based on special circumstances or exigencies in individual states, and short term ways and means advances to provide revenue smoothing.

Until 1999-2000, a second category of borrowing by the states was included in central loans: the center served as intermediary for states' drawing on the National Small Savings Fund, consisting of mostly rural savings collected through post offices. In that year, NSSF loans were separated out in the government accounts, ${ }^{30}$ and have been

most cases, these reports are not easily accessible, and even the FC itself reported difficulties in acquiring the requisite information.

29 This role has implications for the impact of structural adjustment lending (SAL) by multilaterals to support fiscal consolidation - the conditionalities in such loans can be counteracted by the moral hazard inherent in central government guarantees. In fact, Chakraborty and Rao (2006), in a detailed empirical analysis, tackle this issue and find mixed evidence for positive impacts of SAL on fiscal outcomes.

30 The accounting change explains why the latest FC's report (Finance Commission, 2004, Chapter 12), offers a different calculation of the makeup of state debt, than ours, which is directly from the RBI's figures (RBI, 2006, Appendix Table 36). The NSSF facility was also used in a debt swap scheme in 2004-05, to reduce states' older, high interest rate debt. 
nominally securitized, though this remains a captive source of funds. This category makes up about 27 percent of states' debt stock, and the proportion is likely to increase. The interest rate paid to small savers is set by the center, and is higher than market rates, or rates for bank deposits. Effectively, since the center is guarantor, the new accounting brings greater transparency but does nothing to change the incentives of the state governments.

Yet another captive source of borrowing for the states is the mandated pension and insurance contributions of state government employees, minus any payouts that occur. This category accounted for about 12 percent of the states' liabilities in 2005-06. Another, less automatic, but also somewhat captive source of borrowing has been stateowned financial institutions such as the Life Insurance Corporation of India, and various public sector banks. This accounts for 6 percent of state debt. While this was a small proportion of debt, it was one of the fastest growing components of state debt over the preceding decade. ${ }^{31}$

States also "borrow" by delaying payment of bills, and as they came under fiscal stress in the 1990s, this became an increasingly important, albeit precarious means of financing deficits at the state level. One important case of this form of financing by running up arrears was in the case of State Electricity Boards, state-government-owned utilities that failed to pay their bills to the National Thermal Power Corporation, the central government-owned utility company. Some of these deficits and debts were offbudget, and some states also tried off-budget special purpose vehicles to raise funds outside the formal institutional controls of government borrowing. As one might expect, the center and RBI have cracked down on these practices by issuing explicit supplementary orders, and by changing payment procedures in the case of electric power.

All the state level borrowing channels described so far involve either active central government participation, or central complicity through guarantees, permission, and support. In fact, public sector financial institutions are an important source of captive financing for the central government as well. One can view the traditional methods of hierarchical control of state level borrowing as coming under strain as states looked for expedient ways to relieve their fiscal difficulties (including borrowing to fund as much as 50 percent current expenditures). In addition, the political power of the center versus the states arguably declined in this period. The upshot of these developments favors a different approach to borrowing controls, using central authority to set up rules, but allowing market-based discipline to govern borrowing.

Market borrowing has always been available to the states, subject to national government control and discretion, as noted earlier, but its use has increased somewhat in the last few years. For many years, the proportion of market borrowing in state financing of their gross fiscal deficits was in the range of $15-20$ percent. In 2002-03, the proportion was 28 percent, and 38 and 30 percent in the next two years. It has subsequently come

${ }^{31}$ Market borrowing and NSSF loans were the two largest sources of new borrowing by the states, though the latter, as noted, represented an accounting change, substituting for previous "round-tripped" central government loans. Borrowing from pension and insurance schemes also grew rapidly in this period. 
down in 2005-06, to just over 15 percent, but may well rise again, because of specific institutional proposals to increase the importance of market borrowing for the states. Currently, market borrowing makes up almost 20 percent of the states' debt stock. However, much of this borrowing has been through private placements with financial institutions, and interest rates are controlled. More recently, some states have raised funds through bond auctions, with market-determined rates. As noted above, there is also some off-budget borrowing by state level public sector enterprises.

The latest FC report (Finance Commission, 2004, p.12) has made the recommendation that "The Central Government should not act as an intermediary for future lending and allow the states to approach the market directly, through issuing bonds. If some financially weak states are unable to raise funds from the market, the center could borrow for the purpose of on-lending to such states, but the interest rates should remain aligned to the marginal cost of borrowing for the Center." This recommendation moves institutions in the right direction for more efficient fiscal management, but there are still weaknesses in what is envisaged. Direct access to the market usually means that states deemed too risky to lend by the market have to pay a higher interest rate, and this in turn would provide an incentive for such states to be fiscally more responsible and be perceived as less risky. Any on-lending to fiscally weak states at about the market rate for central loans would simply dilute the incentive to be fiscally strong that direct access to the market induces. Instead, the Commission could have recommended that all states have to access the market directly, with some relatively poor states receiving grants that are designed so as not to distort marginal incentives.

The new proposals would represent a major shift in the subnational borrowing regime, since even past market borrowing by the states has been with implicit or explicit guarantees of the central government. ${ }^{32}$ It is still possible that state governments will require bailouts in extraordinary circumstances, but a priori market discipline can restrict the frequency of such occurrences. Note that true market discipline will require other sources of borrowing and central government guarantees to be limited, and lenders to also face the test of the market. ${ }^{33}$ In particular, the states must not have easy access to captive sources of finance, including nationalized financial institutions. ${ }^{34}$ The RBI is exploring the development of institutions to support this shift to market borrowing, including offering mechanisms, secondary markets for government debt, credit ratings, and methods of regulation and monitoring. The FC has proposed ceilings on aggregate borrowing (including state-level guarantees) and debt, and these would be an important component of a market borrowing regime. Several states have included such limits in their FRBM legislations.

\footnotetext{
32 Hence, there has not been a true assessment of the creditworthiness of different states, and the rating agencies do not independently rate the states. In this context, note that central government control of essentially all borrowing by the states has allowed it to make implicit transfers through subsidized loans (Rao and Singh, 2005, Chapter 9).

33 There is a subtle issue related to the overall degree of transfer dependence, and the existence of implicit guarantees, which is discussed in Section 4.5. I am grateful to Jonathan Rodden for emphasizing this point.

34 Thus, this kind of fiscal reform is ultimately closely tied to, and dependent on, financial sector reform (Singh and Srinivasan, 2005a, 2005b). In the past, the center has regularly bailed out states through debt forgiveness, and this would have to be controlled.
} 
Investment expenditures whose benefits will accrue in the future are natural candidates for financing through borrowing, and, to the extent that many local services require infrastructure (local roads, streetlights, parks), borrowing is potentially important for local governments. The efficiency argument for tax collection to be performed by higher levels of government applies for borrowing as well, but the resulting incentive problems can be severe. Local government borrowing in India has been ad hoc and limited in nature. While rural local governments were insignificant borrowers, urban governments increasingly went into debt even before local government reforms, though with substantial differences across states (N.R. Rao, 1986) Almost all such debt was that of municipal corporations and of port trusts (with large, specialized infrastructure requirements. Borrowing was via nationalized banks or other government-owned financial institutions. In many cases, the distinction between loans made by state governments as part of the planning process, and institutional financing of local projects, also routed through the states, was blurred (Datta, 1992). Current data (Finance Commission, 2004, Annexures 8.8 and 8.9) suggests that rural government borrowing was about 1 percent of expenditures for rural governments, and 10 percent for urban governments.

Numerous repayment problems with local level borrowing, going back at least to the 1960s, are noteworthy in the light of the stringent statutory restrictions on local governments in India. These included restrictions on rates, amounts, aggregate borrowing and length of terms. Individual loans require approval of the state and or the central government, as well as consultation with and approval of the RBI. Open market borrowings have also been subject to higher-level government and RBI supervision and approval (Datta, 1984). Local government reform has had only a marginal impact on the previous situation, especially for rural governments. The SFCs have been charged with making recommendations with respect to loans, but the ability to assess projects and monitor outcomes is already beyond the state governments' capacity.

In 1999, the center announced that village level governments (panchayats) would be allowed to borrow from the Rural Infrastructure Development Fund to provide roads, primary education centers, rural health centers and drinking water in villages. The evidence indicates that panchayats did access and disburse these loans to some extent (World Bank, 2000). In the absence of adequate revenue sources, however, it is not clear if this mechanism can be implemented to any great degree. In some cases, rural local bodies have been able to get loans from public sector banks for small infrastructure projects such as constructing marriage halls. These kinds of collateralized loans are made marginally easier by the firmer status of local governments after reform.

Larger urban governments, as before reform, continue to rely on loans from state governments and government financial institutions for infrastructure financing. In many cases, state government departments intercept transfers to these local governments to collect repayments, creating uncertainty in planning and confusion in accounting (World Bank, 2004b). A relatively new development has been the issuance of bonds by a few urban bodies, including municipal corporations as well as specialized government 
organizations such as water supply agencies. The Maharashtra SFC had explicitly recommended the development of a market for bonds for urban and rural local governments, with ratings by agencies such as CRISIL (Credit Rating Information Services of India Limited), CARE (Credit Analysis and Research, Ltd.) and ICRA (Indian Credit Rating Agency). CRISIL, CARE and ICRA each currently list ratings on about a dozen or so urban local bodies on their web sites, these being mostly for governments or agencies in western and southern India. Box 2 provides one example of these ratings.

\section{Box 2: Ahmedabad Municipal Corporation Bond Ratings}

Rs. 1000 Million Tax-Free Bonds (Property Tax) - 2002 AA (so)/Stable (Reaffirmed)

Rs. 580 Million Tax-Free Bonds (Property \& Octroi) - 2004 AA (so)/Stable (Reaffirmed)

Rs. 1000 Million Tax-Free Bonds (Property \& Octroi) - 2005 AA (so)/Stable (Reaffirmed)

Rs. 334 Million Taxable Bonds (Octroi) - 1998 AA (so)/Stable (Rating Withdrawn)

CRISIL's 'AA (so)/Stable' ratings on the bonds issued by the Ahmedabad Municipal Corporation (AMC) are based on the corporation's stable financial risk profile and the credit enhancement mechanism provided for each bond by escrow of octroi and/or property tax collections from designated nakas/zones. The credit enhancement mechanism operates through a trustee-administered escrow account. The current reaffirmation is subject to the trustee(s) confirming compliance with all aspects, including legal documentation and stipulated payment mechanism by July 19, 2006 and fully capitalising the sinking fund to provide for the upcoming put/ call option for 2002 Tax-Free Bonds (Property Tax Bonds) by July 30, 2006. The ratings are also based on the corporation's buoyant revenues, healthy revenue surplus levels, strong economic base, and good economic management. These rating strengths are partly offset by the corporation's high indebtedness levels.

AMC has maintained healthy surpluses, driven by buoyant revenue receipts (RR). During 2004-05 (refers to financial year, April 1 to March 31), the corporation's operating surplus stood at Rs. 2980 million compared with an operating surplus of Rs. 1890 million in 2003-04. The growth in surpluses has been driven by strong growth in octroi and property tax collections over the last two years, which is expected to sustain over the medium term. AMC has a strong and diversified economic base, encompassing well developed industrial, commercial, and residential segments. AMC has also displayed good economic management with respect to property tax reforms and good service arrangements.

The current rating, however, remains constrained by AMC's high levels of indebtedness. The corporation's indebtedness ratio of 52 per cent, as measured by the debt to RR ratio, and debt levels at Rs. 4210 million (as on March 31, 2005), compare unfavourably with other CRISIL-rated municipal corporations. The levels are high due to substantial debt-funded capital expenditure since 2003-04. CRISIL believes that AMC's future indebtedness levels will be contingent on extent of debt-funding of its capital expenditure and extent of financial support provided to Sabarmati River Front Development Corporation.

\section{Outlook: Stable}

CRISIL expects the buoyancy in the revenues of AMC to continue, driven by strong octroi and property tax collections. Further, the debt levels should remain under control, with the funding of its planned capital expenditure mainly through grants.

\section{About the corporation:}

AMC is the largest municipal corporation in Gujarat. AMC covers an area of around 190.80 square kms and provides a range of civic services to around 3.6 million citizens (2001 census) of Ahmedabad and the peripheral areas that come under its municipal limits.

Source: http://www.crisil.com/credit-ratings-risk-assessment/outstanding-ratings-list.htm, accessed August 31,2006 


\section{Diagnosis of Accountability Mechanisms}

In the context of governance, accountability means that members and agents of government, i.e., politicians, employees and contractors are ultimately answerable to the citizens who provide the funds for their functioning, through taxes, fees and loans. For most of government, accountability is somewhat indirect, operating through organizational hierarchies. Only politicians are directly answerable to citizens through elections, ${ }^{35}$ and these are based on aggregate and incomplete assessments by citizens of politicians' performance. Day-to-day accountability of politicians works through mechanisms such as the answerability of the executive to the legislature, the oversight of the judiciary, and general checks and balances within government. A federal structure adds the electoral dimension of accountability to subnational governments, but this can complicate the task of citizens in trying to assess performance.

One can categorize two fundamental types of accountability: (1) that of elected officials to citizens and (2) that of other government employees to elected officials (e.g., Littvack and Seddon, 1999). The first can also be termed accountability through "voice" (Hirschman, 1970) or political accountability (World Bank, 2004b). The second is more complex, since there can be vertical and horizontal chains of accountability within government as a whole, and within specific parts of government. Thus, this type of accountability includes "hierarchy" as a mechanism (Littvack, Seddon and Bird, 1998) as well as checks and balances (Rao and Singh, 2003). One can also term this as "internal" accountability (World Bank, 2004b), broadening that usage to include checks and balances. ${ }^{36}$ Section 2.1 assesses India's internal accountability mechanisms, with an emphasis on the hierarchical mechanisms that operate across levels of government. ${ }^{37}$

One mechanism that provides external accountability is what Hirschman termed "exit." Citizens may exit in two ways, either by shifting jurisdictions, or by going to the private sector for fulfilling wants that the government fails to provide adequately or effectively. In either case, the key enabler of exit is competition, between jurisdictions or between public and private provision. Intergovernmental competition in India is considered in Section 2.2. The issue of private versus public provision of what have traditionally been public services is postponed to Section 3.2, in the context of an integrated discussion of service delivery. A different kind of intergovernmental

\footnotetext{
${ }^{35}$ In India, the broad use of public interest legislation can be seen as citizens' using the judiciary to improve accountability of politicians, where electoral accountability is weak.

36 These are typically ignored, except for Rao and Singh (2003), in the literature cited here, which treats government as a dichotomous entity of elected and non-elected officials and neglects the broader dimensions of within-government accountability. Kapur and Mehta (2006) consider the functioning of the Indian national parliament as an institution of accountability for the executive. In considering forms of accountability, note that public interest legislation (see previous footnote) can be interpreted as a hybrid of external (government-citizen) and internal accountability.

37 One can possibly also distinguish "social" accountability (World Bank, 2004b), referring to the accountability of front-line service delivery units of government to clients. It seems that this is really a derivative of joint political and internal accountability. Yet another aspect of accountability (Littvack and Seddon, 1999) is a division along quasi-functional lines: political, fiscal and administrative. Again, it seems that fiscal accountability, while very significant, is a joint product of political and administrative (internal) accountability.
} 
competition is considered in Section 2.3, focusing on the important dimension of capital for investment at the subnational level. Traditionally, subnational governments in India compete for funds from higher level governments. The shift toward market borrowing replaces this internal, hierarchical accountability with accountability to the market, and to citizens as investors. Finally, Section 2.4 considers the core dimension of electoral accountability and its working at the subnational level in India.

\subsection{Hierarchical mechanisms}

India's states, because of their relative linguistic and cultural homogeneity, have been natural loci and arenas for political organization. As discussed in Section 1.1, in the early days after independence, regional (as well as ideological) differences were mediated through a national political coalition. A strong central party leadership was able to enforce a degree of accountability of state governments, in some cases replacing regional leaders as state chief ministers. One provision of the Constitution that has been used the most to exercise hierarchical political control is Article 356 of the constitution, which allows the governor of a state to advise the president that the government of the state is unable to carry on "in accordance with the provisions of this Constitution", and allows the president to assume "to himself all or any of the functions of the Government of the State". In practice, "President's Rule" means rule by the prime minister and the ruling party at the center.

It is debatable whether the use of Article 356 in practice increased overall accountability. Specifically, accountability of the states to the center through this constitutional provision did not translate into better accountability of elected officials to their constituents: rather, the opposite was the case. State-level elected politicians were, to some extent, able to claim central interference as a reason for lack of performance. Interestingly, as political decentralization has increased, with the emergence of strong, independent regional parties, the use of Article 356 has been challenged more successfully, and its invocation has declined. ${ }^{38}$

The situation of state-local hierarchical accountability in the political arena was much more extreme than the center-state case. While there is a constitutional limit on the length of President's Rule in a state, there was no limit in the case of local governments being superseded by states. Before the passage of the constitutional amendments on local government, at any given time since independence, 40-50 per cent of local government bodies in India had been under state supersession (Dillinger, 1994). Even where there were provisions for direct rural local elections, they could be ignored at the discretion of the state government - in Tamil Nadu, for example, rural local elections were not held for a stretch of 15 years.

\footnotetext{
38 Brass (1994) argues that the increased use of Article 356 to impose President's Rule in the states was a response to increasing political decentralization, rather than an indicator of a movement in the other direction. This is not inconsistent with the argument here, which suggests that what Brass highlighted was a temporary phenomenon and unsuccessful response in the long run. There are several other provisions in the constitution which allow central intervention in state-level politics. See Rao and Singh (2005, Chapter 3) for details.
} 
The 1993 amendments place a limit of six months (the same as President's Rule) on the period of supersession of any local government. While state governments may continue to try and postpone local elections when it suits them (and this has been happening) they will no longer have the law on their side. In the context of accountability, it is important to re-emphasize (as was discussed in earlier sections), that this system of strong hierarchical political control did not translate into good performance in delivery of public goods and services. If accountability can be inferred from such performance, then the basic accountability of government to citizens does not appear to have been enhanced by hierarchical accountability.

It can be counter-argued that the situation may have been worse without higher level government intervention, and that possibility must be considered. In other words, higher level "takeovers" may be justified responses to poor lower-level performance. This is difficult to assess empirically, but it does suggest that day-to-day accountability mechanisms, operating mainly through the bureaucracy, may be more important than observation of extreme measures. As our discussion in earlier sections would indicate, these are quite different at the state versus the local level.

States have a reasonably well-defined locus of authority, and longstanding, competent bureaucracies. While they depend on the center for a significant portion of their funds, there is a relatively transparent and independent (though not optimal) procedure for making these transfers. Tax sharing and unconditional grants through the FC require no formal accountability to the central government. Even PC grants are mainly formula-based, and while the $\mathrm{PC}$ is nominally responsible for monitoring outcomes and could conceivably adjust future transfers based on performance, this does not happen at all. It is only central ministry transfers, in the form of various "schemes," where conditionalities are built in very strongly. Again, however, the actual monitoring of the use of even these funds is poor, 39 and one can characterize the hierarchical accountability of the use of funds through center-state transfers as weak. Note that this is distinct from a formal maintenance of budgets and accounts, since the state government accounts are typically reasonably well-maintained 40 at a formal, aggregate level. The $\mathrm{RBI}$, acting as an agent of the center, collects data and reports on the states' finances, providing an accurate overall picture, and the states' own accounts give further details.

State level bureaucracies are also connected to the national bureaucracy, and this affiliation creates another avenue of accountability. The Indian bureaucracy, as conceived by the British (and to some extent, the Mughals before them) was designed to maintain basic law and order and efficient revenue collection. The system was built around district

\footnotetext{
39 Matters are complicated by the poor design and large number of these various schemes, in addition to poor incentives for implementation. More recently, some states under fiscal stress have liberally used transfers supposedly earmarked for developmental projects to meet their basic salary obligations. Examples of studies of state-level financial accountability mechanisms include World Bank (2006b), on Punjab. Further references, for World Bank studies of other states, are contained in that document.

40 The quality of budgeting and accounting varies across states, and there are problems common to all states. See World Bank (2004b), and the references in the previous footnote.
} 
level administrators with substantial powers and discretion. Independence saw attempts to expand the duties of these administrators to encompass a whole range of functions meant to promote economic development. State level political control became more important than in the past, as democratic institutions supplemented hierarchical administrative control. The core of the state-level bureaucracy (the IAS and Indian Police Service) remains tied to the central bureaucracy, but the accountability that this creates (through competition for promotion to the highest level central posts) is countervailed by political pressures that can vary across states. Specifically, corrupt politicians at the state level can override hierarchical accountability mechanisms that are internal to the bureaucracy.

In addition to direct political pressures on bureaucrats that distort supposedly impartial administrative decision-making, there are distortionary incentive mechanisms such as frequent transfers of bureaucrats. Even in the 1950s, transfers were used to reward and punish bureaucrats (e.g., Sivaraman, 1991). In some cases, transfers are a part of an elaborate rent-seeking and rent-distribution mechanism, where administrators and politicians may be equally complicit (e.g., Wade, 1989; De Zwart, 1994). One theoretical justification for transfers ${ }^{41}$ is that of reducing corruption by reducing opportunities for enduring corrupt relationships to develop between bureaucrats and their clients, but in practice the frequency, variability and arbitrariness of transfers is much greater than would be indicated by any such justification. The outcome is that the bureaucracy's role in carrying out administrative policies that are derived from underlying legislative goals is severely hampered. One can view this problem as resulting from a situation in which political accountability weakens the hierarchical bureaucratic accountability that is subordinated to it, but is itself ineffective. Better insulation of bureaucratic transfers from inappropriate political pressures (i.e., driven by rent-seeking and corruption rather than by citizen preferences) is a significant component of an emerging reform agenda for the Indian civil services (e.g., Saxena, 2005). ${ }^{42}$

At the local level, the situation is different because of the continuing political, financial and administrative limitations on local governments, despite their new constitutional status. Some of the problems are structural. Most obviously, the insufficient assignment of revenue authority constrains local governments in all three of these dimensions. There are also structural limitations in the new political arrangements, ostensibly designed to promote political accountability, but serving in practice to maintain control of resources by elected officials of the state and national governments. This is particularly true for rural governments: members of parliament and of state legislatures can serve on governing councils at the block (intermediate) and district levels. In essence, the pre-reform system of hierarchical control of local governments remains largely intact.

\footnotetext{
41 An additional, more positive rationale comes from the benefits of varied experience that come with rotation of assignments, especially for younger bureaucrats.

42 Reform attempts are as old as the problems, and the Indian government has made various attempts at administrative reform, going back at least to the 1960s (Rao and Singh, 2005). Howes, Lahiri and Stern (2003) and Kapur and Mehta (2005) include various previous academic studies of administrative reform issues for India, and comparisons to other countries.
} 
This pre-reform hierarchical accountability system was ineffective in delivering services at the local level (see Section 3.3 below). At the same time, examples of misuse of funds through incompetence, malfeasance, or both, were common before reform (Rao and Singh, 2003). The level of auditing, both quantitatively and qualitatively, was inadequate, applying not just to the identification of irregularities, but also to the enforcement of minimum accounting standards. Also, more effort was devoted to other kinds of monitoring rather than to auditing or performance monitoring. Local government in India involved excessive control of inputs and process, to the detriment of attention to performance and outcomes ${ }^{43}$. Examples were common of detailed approval required from higher level governments for relatively small projects or expenditures, sometimes as part of a top-down national and state planning exercise in which local governments had little input. At the same time, performance could often be neglected, with overdue and abandoned projects being common. In sum, the implementation of accountability through 'hierarchy' has been flawed.

An additional aspect of this situation is that the (external, political) accountability of state governments for local government performance has itself been weak. Hierarchy as a mechanism for accountability just pushes a greater burden on to 'voice' at a higher government level. This conceptual point does not seem to have been explicitly recognized in the evolving literature on decentralization ${ }^{44}$. Another point that deserves consideration is that hierarchical accountability may have an inherent tendency to undermine assignments of authority to lower-level governments. This is the fundamental problem of the higher-level government in a federal system 'overawing' lower-level governments (Riker, 1975).

Interestingly, post-reform, the central government has been seeking to increase the accountability of state governments for local government performance. After the last general election, in May 2004, the new government at the center proposed transferring money directly to local governments, rather than through the states. As one might expect, this was vigorously opposed by the states. The last three FCs, which reported after the 1993 reforms, have also worked to get the states to carry out their constitutionally mandated and legislated responsibilities to local governments, in addition to directly supporting local government capacity building through various conditional and unconditional transfers (all required to be channeled through the states). As the FC reports make clear, one of the main problems in holding local governments accountable for their own performance, and state governments for local performance, is the lack of reliable and detailed data: information and transparency are key inputs for any kind of accountability mechanism to work.

\footnotetext{
43 The choice between input and output monitoring is a complicated one, since certain means may be undesirable in themselves, if they involve corruption or illegality, even though the ends are thus achieved. Mookherjee (1997) analyzes these and other issues in a model of tax administration. See also the references in that piece.

44 See, for example, World Bank (1997), Litvack et al (1998), and Litvack and Seddon (1999). Such analyses tend to appeal to lack of institutional 'capacity,' rather than the fundamental problems with 'hierarchy' as an accountability mechanism
} 
Finally, we briefly consider the working of checks and balances as accountability mechanisms in the Indian case. These are not strictly hierarchical, but share the characteristic of being internal to the government. As we have indicated earlier, accountability of the executive to the national legislature has typically been weak (Kapur and Mehta, 2006). The quality of parliamentary debate, in questioning levels of performance in meeting government responsibilities to citizens, is relatively poor. With some generalization, and ignoring variations across states, this is true of state-level legislatures as well. In recent years, driven somewhat by public interest lawsuits, higher level courts (the Supreme Court and some state High Courts) have stepped in to enforce government performance, but this is more in the nature of an indirect external accountability mechanism, rather than a standard checks and balances mechanism. The latter would involve the judiciary restraining the powers of the other two branches, or acting as umpire between them, or between different levels of government. The courts have played this role in the past, with the Supreme Court called upon in several important cases (see, e.g., Rao and Singh, 2005, Chapter 3). In any case, judicial intervention, by its very nature, cannot be an effective mechanism for day-to-day internal accountability.

\subsection{Intergovernmental competition}

Before the economic reforms of the 1990s, state governments were severely constrained in terms of their economic policies. ${ }^{45}$ They could choose tax and expenditure policies according to their constitutional assignments, and within the further constraints imposed by central government policies that emphasized central planning and centralized direction of the allocation of resources. Since private and public investment was largely directed by the central government, there was a minimal role for state governments to compete with each other for private sector capital flows. Instead, competition took place (and still does) for central government resources through the channels discussed earlier, in Section 1.5. State level policies were also influenced by intra-state competition for political power (e.g., Rao, 1979, 1981; Dutta, 2000).

One long-standing aspect of inter-state competition that did pre-date economic reform was in the setting of sales tax rates. Adjacent states have sometimes set low tax rates on some goods to attract cross-border purchases from adjacent jurisdictions, and hence (assuming an appropriate elasticity of demand and adjacent market size) enhance sales tax revenue. There were several instances where automobiles and consumer electronics were taxed at the same or lower rates than food grains and edible oils, contrary to the objectives of equity which had originally motivated sales tax rate differentiation. In general, this kind of inter-state tax competition in India led to allocative inefficiencies, as well as distributional inequities (Rao and Vaillancourt, 1994). As part of a general overhaul of the sales tax system in India, including the introduction of a value added tax (VAT), there have been attempts to achieve some degree of tax

\footnotetext{
${ }^{45}$ As will be clear from our earlier discussion, local governments remain severely circumscribed in the policies they can undertake to attract economic activity. Even large metropolitan areas are governed by state level policy in terms of land use, industrial development, and so on. In particular, significant urban land is typically controlled by state governments rather than municipal corporations.
} 
harmonization, and control harmful tax competition (e.g., Rao and Rao, 2006; Singh and Srinivasan, 2006). One aspect of the indirect tax system and its reform that is important to mention here is the choice between an origin-based (the current) system and a destination-based one (as has been proposed for the VAT). While neither approach dominates in terms of welfare or efficiency (Oliveira, 2001), an origin-based system can distort producers' location decisions, and this would be a greater consideration for managing inter-state tax competition in the future.

The reforms of the 1990s generally gave state governments more freedom to make policies independently. In particular, states can now seek to affect the incentives of external capital to enter their jurisdictions. An early analysis by Bajpai and Sachs (1999, Appendices I through $\mathrm{V}$ ) documented in summary form the policy measures taken by various states to attract external capital, particularly FDI. The outlines of policy reforms appeared quite similar, but implementation, based on qualitative assessments, varied much more, suggesting that some states were much more successful in actually reforming. The dimensions of reform and policy incentives included industrial policy controls, tax and financing incentives, and land and infrastructure provision. In some cases, state governments were able to build on already attractive investment environments (Mumbai for Maharashtra and Bangalore for Karnataka), while in others, such as Andhra Pradesh and Tamil Nadu, government policy appears to have played a more pivotal role in attracting new investments. In some sectors, particularly information technology (IT) and IT-enabled services such as call centers and business process outsourcing, the central government also provided some assistance to state governments (e.g., for software technology parks, or STPs), but these were notionally uniform across states, so that successful implementation depended very much on state-level policies and actions. For example, Tamil Nadu's STP in Chennai was an early success, whereas that of Punjab is only now being developed, with a lag of several years.

The importance of policy was also suggested by the analysis of Singh and Srinivasan (2005a), who examined state wise data for total FDI approvals for the decade 1991-2001 The simple correlation of per capita FDI approvals with a state-level infrastructure index was less than 0.1. This partly reflects the use of FDI approvals rather than actual investment, and the limitations of the infrastructure index. ${ }^{46}$ To the extent that variations in FDI across states were influenced by specific policy initiatives and narrowly focused government investments in infrastructure, such as might be the case in Andhra Pradesh, Karnataka or Tamil Nadu, there is scope for state governments to compete more effectively for FDI that might itself have a longer-term impact on infrastructure. For example, Punjab, with the highest index of infrastructure, lagged substantially in FDI, but appears to be changing this situation with recent policy adjustments. ${ }^{47}$

Dollar, Iarossi and Mengistae (2002) were able to examine the quantitative impact of some dimensions of state-level variations in policy on manufacturing productivity.

\footnotetext{
46 For example, a state such as Karnataka is measured by such indices as having very low infrastructure development, despite its concentration of workers with high levels of technical skills.

47 Singh (2007), based on interviews with entrepreneurs and government officials, found that in the early 2000s, the policy environment in Punjab was quite inimical to new investment.
} 
Using a survey of 1000 manufacturing establishments across 10 Indian states, they found that states that were poor performers, and identified by survey respondents as having a 'poor investment climate', had total factor productivity (TFP) that was 26 percent lower than the high-performing states. About a tenth of this gap was found to be due to a higher regulatory burden (specifically, labor market regulations and their implementation) in the worse states.

Figure 1: NCAER Incentives Index (1996)

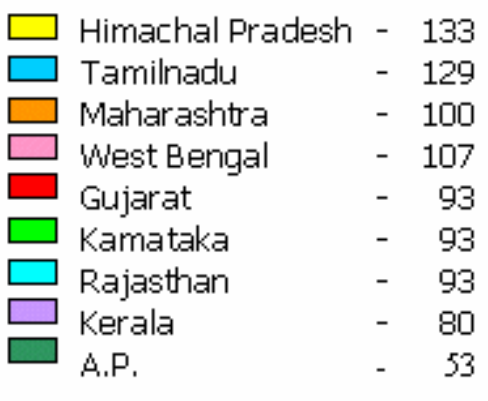

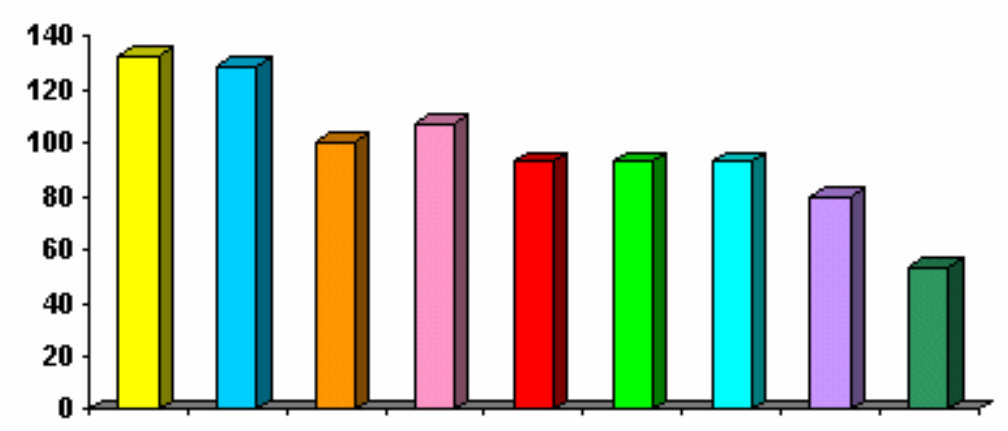

More general quantitative state-level analyses of the impacts of policy reform are not apparently available, though compilations of investment incentives and industrial policies across the states of India are available. ${ }^{48}$ Box 3 provides a specific state example. An early study (National Council of Applied Economic Research, 1997) constructed an index measuring the attractiveness of state incentive packages (Figure 1), but there does not appear to be an update of this exercise - in fact, states that scored well on this index continue to advertise the fact, omitting the date of the study. ${ }^{49}$ There are also rankings of states in terms of quality of life (Bhandari and Debroy, 2006) - important for attracting skilled workers, ${ }^{50}$ economic freedom (Debroy and Bhandari, 2005) - used as a measure of attractiveness for doing business, and overall competitiveness (National Productivity Council, 2004). The competitiveness measure included an index of governance quality, which, in turn, included measures of state policies with respect to business and investment. These various indices and rankings provide some indication of the degree to which state policies differ in practice, though they often capture exogenous factors along with endogenous policies.

Given the divergence of economic performance of India's states in the postreform era (e.g., Rao, Shand and Kalirajan, 1999; Ahluwalia, 2002; Rao and Singh, 2005;

\footnotetext{
48 A good example is at the web site "India in Business" (http://www.indiainbusiness.nic.in/investindia/State-govt-index.htm), compiled by the industry association, Federation of Indian Chambers of Commerce and Industry (FICCI), for the Ministry of External Affairs.

49 See, for example, http://www.indiainbusiness.nic.in/indian-states/tamilnadu/IncenInves.htm.

50 As would be expected in a surplus labor economy, there is little evidence that states or cities compete for less skilled workers through the provision of basic public amenities. While the highly skilled are very mobile, labor mobility in India is generally very low (Munshi and Rosenzweig, 2005).
} 
Singh and Srinivasan, 2005a), it is plausible to assign some of the differences to state level policy variables. Differences in growth performance are explained by differences in private investment, public expenditure, and infrastructure quality, among other variables. State-level fixed effects in panel data studies are also significant, and can be interpreted as capturing unmeasured differences in institutions and policies. However, there has been no direct general empirical link established between state-level policies that aim to compete for external capital (both domestic and foreign) and resulting economic performance, with the Dollar, Iarossi and Mengistae (2002) study as a limited exception. ${ }^{51}$

\section{Box 3: Gujarat Investment Incentives}

Incentives to industries

1. Any small scale unit set up with its own investment can avail $10 \%$ limited to maximum Rs. 10 lakhs of the eligible fixed capital investment under interest subsidy or investment subsidy scheme - 2000 .

2. Any small scale unit set up with the loans from financial institution or any existing small scale unit going for modernization program can avail of 5\% subsidy on the applicable interest over the loan period, limited to Rs. 5 lakhs per annum totaling to Rs. 25 lakhs. This subsidy is limited to 3\% in case of expansion or diversification of the existing small scale unit limited to RS. 3 lakhs per annum totaling to Rs. 15 lakhs.

3. In case of declared backward areas by the Government, the subsidy mentioned under (1) and (2) in increased by $25 \%$.

4. Any medium or large scale unit having incurred cost for creation of infrastructure can avail $25 \%$ subsidy limited to Rs. 100 lakhs under medium and large scale units subsidy scheme - 2000. The upper limit is extendable to Rs. 250 lakhs for schemes under rural linkage projects.

5. Under New Industrial Policy - Assistance for Research and Development and Patent Registration scheme, assistance will be provided by the State Government on specific proposals on merits for activities related to research and development. Assistance will be provided at the rate of $50 \%$ limited to Rs. 5 lakhs for patent/ IPR.

6. Any unit with minimum investment of Rs. 20 crores set up after 31st July 2001 till 31 st July 2003 in Kutch district of Gujarat can avail of excise exemption benefit of maximum 5 years from the date of commencement of commercial production.

7. Under Incentive scheme 2001 for Economic Development of Kutch District, any unit set up between 31-7-2001 and 31-10-2004 can avail of sales tax exemption or sales tax deferment or composite scheme for units having capital investment exceeding Rs. 100 crores for a period of 5 years from the date of commencement of commercial production.

8. 92 talukas of 21 districts are declared by the State Government as backward areas which are eligible for enhanced benefits under various schemes mentioned above

Source: http://www.indiainbusiness.nic.in/indian-states/gujarat/investmentincentivesindex.htm

It is also not clear to what extent inter-state competition has affected the states' fiscal positions. As we shall argue in Section 3.1, other factors such as agricultural

51 There are also a few case studies of such competition, e.g., that between Maharashtra and Tamil Nadu for a Ford-Mahindra automobile production plant (Oman, 2000). In this case, Tamil Nadu won on the basis of infrastructure and skills availability, while incentives ranked only $7^{\text {th }}$ in importance. 
subsidies and large pay raises for government employees are most likely the dominant proximate causes of the states' declining fiscal situations since the 1990s. The data suggest that increases in such expenditures have led to increasing deficits, rather than declining tax revenues, though the counterfactual in the latter case is a unit elasticity of state tax revenues with respect to GDP. The Twelfth Finance Commission report (Finance Commission, 2004, Chapter 6) uses normative marginal elasticities ("buoyancy ratios") ranging from 1.1 to 1.35 for different states in making its projections. The difference between these prescriptive values and the data could be due to tax incentives provided by states to attract external capital, but is more likely due to overall poorly designed and implemented tax systems (Section 1.4 above) than to specific fiscal incentives for industry. For example, with sales tax revenue making up a little over 60 percent of states' own tax revenues in 2004-05 (RBI, 2006b, Appendix Table 3), it is unlikely that a 10 percent reduction in tax revenues (implied by a counterfactual buoyancy ratio of 1.1 instead of the observed unity) could have come from sales tax incentives alone.

At the local level, as may have been clear from the discussion of local government powers and functioning in Section 1, there is little scope for explicit competition for economic activity. Mathew (2004) describes the situation as follows, "The role of local government is essentially distributive rather than productive. It is this anomaly of policy perception that still keeps panchayati raj institutions as an appendix to governance structures in the country." This observation is particularly germane because local government competition as a spur to economic activity has been identified as an important ingredient in China's rapid growth (e.g., Cao, Qian, and Weingast, 1999; Jin, Qian, and Weingast, 2005), which has become a benchmark for India's economic performance.

In concluding this section, we can summarize as follows. It is clear that, since economic reform began, state governments have quite aggressively pursued policies to attract external capital. However, the efficacy of these policies, their economic impacts, and the consequences for state government budgets remain uncertain, especially with respect to any quantitative assessment. It is also not clear to what extent competition among nearby states has cancelled out incentives, in an inefficient non-cooperative equilibrium of state policies. Broader empirical work (Lall and Chakravorty, 2003) and anecdotal evidence in the media do suggest that industrial location in India is sensitive to a variety of economic factors, and the quality of governance appears to matter in this reading of the evidence (National Productivity Council, 2004), more than specific tax/subsidy incentives.

\subsection{Credit markets}

Traditionally, state borrowing through bond issuance has been heavily controlled.

The process has been managed by the RBI, and the bond issues placed with banks and other financial institutions at administered interest rates, typically the same for all borrowers. Hence, the issue of testing creditworthiness of state bonds in the market has not arisen in the past. As discussed in Section 1.6, there are now concrete proposals and 
steps being taken to shift the states toward true market borrowing, with independent credit ratings and interest rates determined by supply and demand.

The central government itself made the shift to market-determined interest rates for its borrowing relatively recently, and the market for central government bonds is in its infancy. There are few dealers who are eligible to participate in primary auctions, the secondary market is thin, and the RBI maintains restrictions on short selling, futures and other derivatives. In fact, the corporate bond market is also underdeveloped in India, with corporate and other private sector bonds (e.g., those of development finance institutions, or DFIs) representing a small percentage of the total market capitalization (Patil, 2001). The newness of the market, and restrictions on instruments that might allow better risk management in the face of the uncertainty associated with novelty, work against a rapid development of the bond market. Banks, which hold government bonds in excess of statutory requirements, are also reluctant traders in the bond market. The domestic credit agencies (CRISIL, CARE and ICRA) do not assign (directly) ratings to central or state government bonds. ${ }^{52}$ Instead, Moody's and Standard \& Poor's provide overall sovereign debt ratings for India, ${ }^{53}$ as they have done in the past.

The development of domestic credit ratings for government debt has therefore begun with state-level public enterprises, municipal corporations and special purpose vehicles at the state and municipal levels. There is a variety of financing approaches taken, with some cases introducing a minimum of market involvement, relying on partial funding from higher level governments, multilaterals or other financial intermediaries, and various guarantees. In other cases, there has been direct sale of bonds to the public as well as financial institutions, without any guarantees. ${ }^{54}$ Since the first municipal bond issue was only in 1998, and most issues have been much more recent, there is little history or experience to judge the long-term performance of the market as a monitoring and disciplining mechanism for these bond issues. One of the main issues remains the development of state and local government capacity to formulate projects and associated capital issues to meet market tests. Nevertheless, there are some positive initial developments, in terms of design of financing, managing risks, and involvement of beneficiaries (e.g., the Tamil Nadu Urban Development Fund).

As noted in Section 1.6, the domestic credit rating agencies all provide ratings for the various bond issues at the municipal and state-enterprise level. These ratings are determined on standard criteria (see, e.g., Box 2), having to do with the borrower's capabilities and performance. International experience has led to well-recognized guidelines for assessing credit risks (Peterson, 1998). In this context, the weak revenue authority of local governments, as well as poor revenue collection practices (see Section

\footnotetext{
52 The domestic rating agencies offer ratings of bonds issued by state government agencies for specific projects or ongoing investment in particular sectors - since these bonds are backed by the relevant state governments, their rating effectively involves an explicit assessment of the state government finances.

${ }^{53}$ CRISIL partners with Standard \& Poor's, CARE with Fitch, and ICRA with Moody's.

${ }^{54}$ Numerous studies survey the Indian experience at the local government level, though often covering the same few examples. See, in particular, Bagchi and Kundu (2003); World Bank (2004a); Venkatachalam (2005); Pradhan (2003).
} 
1.4 above) would act as significant barriers to positive assessments of credit risks for most urban local bodies in India. Some analyses of ratings methodology and practice in the Indian context (e.g., Kundu, 2001) express concerns with ratings implementation. The argument is that local government accounts are not reliable enough for accurate ratings. Indeed, it is suggested that local governments under pressure to raise funds from the market may distort their accounting. This is not an argument against market borrowing or credit rating, but does illustrate the difficulties of creating a new institutional infrastructure. Again, the importance of prior reform in budgetary practices is highlighted, as a pre-condition for a successful market for subnational debt. ${ }^{55}$ Another issue that has been raised concerns political influence on credit ratings. Ultimately, the credit ratings agencies themselves will have to maintain reputation, and the existence of competition among them should ameliorate early concerns or problems with the quality and objectivity of credit ratings.

Finally, there is little evidence that credit ratings have an ongoing effect on municipal finance in India. Again, the market is too thin and too new for there to be any real experience or history. Credit ratings are typically only long term, and do not appear to be adjusted with any great frequency, though this might be expected since the handful of financed projects are too new or recent to be capable of meaningful reassessment. In general, one can argue that the proper sequence of development might be national bond markets, then development of state and local project assessment and management, and revenue capacity, with a full-fledged market for subnational borrowing following on these broader and more fundamental reforms.

\subsection{Democratic channels}

Theoretical models of the democratic political process typically assume some kind of electoral responsiveness (e.g., Downs, 1957), driven by politicians' preferences for re-election. This responsiveness may be to individual voter preferences (sometimes ordered or aggregated in a way that makes elected officials responsive to the median voter), or to groups of voters, i.e., interest groups. In the latter case, lobbying or political pressure by well-endowed groups can lead to biased outcomes. Democratic responsiveness may also be altered when candidates have their own ideologies or preferences, and do not merely carry out voters' wishes (Lipset, 1960; Wittman, 1973). Different assumptions about politicians' objectives, the electoral process and the distribution of voter preferences and resources lead to varying predictions about the outcomes of democracy. In a federal system, a further issue concerns the locus of policies that are determined by elected officials. Since voters, in choosing elected representatives, are implicitly choosing among bundles of policies, decentralization can allow incentives working through the democratic process to be more refined. Alternatively, centralization may allow better policy coordination (Seabright, 1996; Rao and Singh, 2003). Finally, another dimension of political competition occurs when legislative coalitions must be formed after elections: policies may be determined by the need to maintain such coalitions.

\footnotetext{
55 See the studies in Morris (2003), Section 8, for examples of budgeting practices and budget reform at the municipal level.
} 
At the national level, the process of organizational decay and reduced political influence of the once-dominant Indian National Congress, coupled with the rise of the Bharatiya Janata Party (BJP) as a national "right-wing" party, and the emergence of regional and caste-based parties, has been touched on in Section 1.1, and extensively analyzed elsewhere (e.g., Rudolph and Rudolph, 1987; Brass, 1994; and Kohli 1990). Even in the past situation of a strong national party, the need to mobilize electoral support at the state level influenced national policies, but this became more important with greater national electoral competition. In the 1960s, the communist party emerged as a regional force in Kerala and West Bengal, while Tamil Nadu saw the first example of dominance by avowedly regional parties.

Chhibber (1995) explains the deepening of 'rent-seeking' - including the persistence of the laws that make it possible - in terms of the intensifying needs of political competition. Essentially, powers of patronage for electoral support became more important in the 1970s and 1980s, overwhelming any concerns about the inefficiency of the system from the perspective of economic growth. Chhibber provides empirical evidence that central loans, food assistance and subsidies to the states were all linked to electoral considerations. Similarly, Rao and Singh (2005), Kapur and Mehta (2002), and others have argued that large payments were directed by the center in the late 1990s to the states (Andhra Pradesh and Punjab) from which regional parties that were key coalition partners originated. In this case, the political support mechanism was more direct, the objective being to build a majority coalition in parliament after elections, whereas in Chhibber's analysis it derived from the pre-election need to mobilize statelevel political resources for national elections. Rodden and Wilkinson (2004) find empirical support for the proposition that distributive politics in India changed in the 1990 s as a result of the shift from single party dominance to coalition governments.

Many other studies examine the impact of central government transfers on statelevel policy choices, and mostly find evidence of political motivations in some transfer channels (e.g., Biswas and Marjit, 2000; Rao and Singh, 2002; Das-Gupta, Dhillon and Dutta, 2004; Khemani, 2004, 2006a,b; Purfield, 2003; Singh and Vasishtha, 2004). Thus, the evidence suggests that the central government tries to influence voters at the state level through this indirect mechanism. One complicating factor for these studies that has emerged over time is the de-linking of national and state-level elections, which now typically occur at different times, rather than simultaneously, as was the case in the first two decades after Indian independence. On the other hand, Khemani (2001) looking at both national and state elections, finds evidence that voters reward (punish) governments for good (poor) economic performance, but do so more vigilantly at the state versus the national level. This result is consistent with recent survey evidence, which indicates voters look primarily to state governments for provision of many important public goods (Chhibber, Shastri and Sisson, 2004).

Focusing exclusively at the subnational level, Rao's $(1979,1981)$ pioneering study of four states found that political competition factors affected tax and expenditure patterns. Dutta $(1996,2000)$ found that states with unstable coalition governments tended 
to spend more and raise less non-tax revenue. Note that these studies at the national and subnational levels tended to focus on expenditures, rather than outcomes. In fact, much of this expenditure took the form of various implicit and explicit subsidies, for agricultural inputs and outputs, and for employment, rather than pure public goods. Thus the link between electoral competition and actual delivery of public goods was not as wellestablished. However, media accounts of recent elections have suggested that voters increasingly expect improvements in areas such as water, electric power and roads, and punish incumbent state governments for failures in these domains by switching to opposition parties. Other studies at the subnational level also suggest that both social conditions (Banerjee and Somanathan, 2001, 2006; Kochar, K. Singh and S. Singh, 2006) and political institutions such as reservations for scheduled castes and tribes (Pande, 2003) affect the allocation of public goods: these studies indicate the limits of pure electoral competition in determining outcomes.

Much of the recent work on electoral accountability has focused at the local level, where the measurement of local public good delivery can also potentially be more precise, through geographically concentrated survey data. As noted earlier, regular direct local elections have the potential to increase the accountability of local government by providing more direct and refined incentives to please constituents. The counter argument is that interest groups or powerful individuals will instead have more influence at the local level. ${ }^{56}$ In fact, concerns about elite domination of elected rural local bodies, have existed since independence, and heavily influenced India's federal design.

Early, pre-reform qualitative studies of local government found examples of interest group capture, as well as positive impacts of local democratic processes. For example, Dash (1988, p. 223) gave examples of the Puri Municipal Council in Orissa providing reductions in, or exemptions from octroi taxes to specific commercial products, benefiting local interest groups. Many case studies mention or imply the reluctance of local governments to impose taxes, being responsive to their constituents in this respect (e.g., Aziz, 1998). More recently, Jha, Rao and Woolcock (2005) found that while formal government channels in a Delhi slum were accessible mainly to the well-off, informal governance structures arose at the community or neighborhood level, which then provided more general access to public services through their leaders' links to elected politicians in the municipal council or legislative assembly.

On the positive side, with respect to elite domination, as long ago as 1965, Andre Béteille observed, in his study of a rural area of Tamil Nadu, "Adult franchise and Panchayati Raj have introduced new processes into village society" (p. 221), and "political and legislative changes have altered the bargaining positions of the old economic classes" (p. 223), arguing that local elections increased the power of those who were worse off but were in greater numbers, rather than perpetuating or increasing

\footnotetext{
56 Bardhan and Mookherjee (2000) provided an early analysis of the problem of "local capture," while Banerjee and Somanathan $(2001,2006)$ found that local heterogeneity distorted the pattern of delivery of public services. Kochar, K. Singh and S. Singh provide a more micro level analysis that captures institutional features of rural spending, and helps explain some of these results in more depth. See Keefer and Khemani $(2003,2005)$ for an overview of some of this literature, and related issues.
} 
domination by the traditional rural elite. Another example is urban. While the Shiv Sena is better known for other aspects of its ideology, its success as a political organization was also built on its attention to ward and municipal constituencies in Mumbai: it achieved electoral rewards by being responsive to those near the bottom of the economic ladder (Naipaul, 1975).

Local government reforms have spurred data collection and research on the impacts of new institutions for 'voice' in India. Studies of South India (Chaudhuri and Heller, 2003; Besley, Pande and Rao, 2006b) suggest that participation in village assemblies (gram sabhas) is driven by self-interest, as well as affected by factors that can be changed through policy interventions. Thus, participation in this new avenue of direct democracy has been encouraging, despite initial concerns about its efficacy. More significantly, there is evidence that local electoral participation is beginning to influence outcomes. Chaudhuri (2005) found that decentralized resource allocation in Kerala did improve perceived delivery of roads, housing and child development services, with the decentralization involving devolution of budgetary authority to elected rural local governments. Besley, Pande and Rao (2006a, b) and Besley, Pande, Rahman and Rao (2006) for southern India, and Bardhan and Mookherjee (2006a,b) for West Bengal in eastern India also find evidence that electoral competition affects the nature and pattern of allocation of local public goods and services. Again, all these studies find evidence that initial social conditions such as education and caste, as well as the precise structure of political institutions matter for outcomes (e.g., Chattopadhyay and Duflo, 2004 for seat reservations at the local level). These may be necessary and acceptable limits on the efficacy of the political process. While we cannot precisely compare outcomes of state and local electoral accountability, it appears that the experience of decentralization to the local level in India has had some positive outcomes, and has not been subject to extremes of local capture. Subnational corruption and capture, as well as less extreme cases of interest group influence, are discussed in more detail in Section 3.3.

One final point is that positive results on local electoral responsiveness are emerging even though the institutional structures are generally far from supportive. Besides the lack of independent revenue authority, local governments are still potentially subject to control and interference from state-level bureaucrats and politicians over their entire domain of expenditure authority. Furthermore, local governments are often restricted in key areas such as land use, where state governments retain control.

\section{Analysis of Implications}

In reviewing India's institutions of intergovernmental relations (fiscal and otherwise), and the accountability mechanisms that function within those institutions, we have commented at several points on problems of performance or effectiveness. This section examines three aspects of outcomes more explicitly. First, it reviews the situation with respect to fiscal deficits, and attempts to control burgeoning deficits at national and subnational levels. Second, the quality of service delivery is examined, particularly with respect to the impact of decentralization. Third, issues of corruption and capture with 
respect to different levels of governance are examined. Again, the impact of decentralization is the major focus.

\subsection{Fiscal discipline}

India has struggled with fiscal discipline for over fifteen years. India's fiscal situation began to deteriorate in the late 1980s, at the central and state levels. The crisis of 1991 led to a tightening, but fiscal deficits began to rise in 1997-98 at both levels of government, though the rise was much greater at the state level (Table 11). Fiscal balances at both levels were severely affected by the large pay increases granted to central government employees in 1997-98, by the Fifth Pay Commission, followed by similar increases at the state level the following year. ${ }^{57}$ The center's balance continued to deteriorate slowly till 2001-02, when the trend was reversed. The states' aggregate position stabilized after the one-time shock, and improved after 2002-03. Two other fiscal indicators also deteriorated after 1997-98. The revenue deficit (i.e., balance between current receipts and expenditures) grew as a percentage of GDP, coming down to 199798 levels only in 2004-05. The primary deficit (after taking out net interest payments from expenditures) has grown, after the initial reduction in the early 1990s, indicating that the problem is not simply growing interest payments, though these have also gone up as a percentage of GDP. Fiscal deficits financed by borrowing have added to the government debt (Table 12). After some decline in the early 1990s, the stock of government debt rose steadily after 1997-98, as a percentage of GDP, before stabilizing from 2002-03. A significant portion of this increase was at the state level. For example, the debt-GDP ratio of the states increased from 21 percent in 1996-97 to 31 percent in 2002-03.

In addition to the stabilization or slight improvement in the center's and states' main fiscal indicators, government guarantees have also been controlled, falling from 12.2 percent of GDP in 2001 to 9.9 percent in 2005, though the latter figure is provisional (RBI, 2006, Table 1.36). The external debt is also under control (16 percent of GNP in March $2006^{58}$ - which is classified as low by international standards), and foreign reserves are at very comfortable levels (\$162.9 billion in June 2006). On the other hand, the future cost of the pension system remains a serious issue for the medium and long run. The World Bank estimates that the cash-flow deficit of the Employees' Pension Scheme (EPS), which is a defined benefit scheme, will grow to almost 1 percent of GDP over the next few decades, even without increases in coverage.

Looking at the states in more detail, they had nonexistent or negligible revenue deficits before the late 1980s, but in aggregate have always been in revenue deficit from 1987-88 onward. Their aggregate revenue deficit increased from an average of 0.62

\footnotetext{
57 These increases at the state level were certainly not mandated, but appear to have been driven by a kind of social norm regarding the relative pay of central and state-level bureaucrats. The fact that key central bureaucrats (e.g., from the IAS and IPS) serve at the state level would make such comparisons salient. 58 This figure is from a Ministry of Finance Press release, August 2006, accessed on December 13, 2006 at http://finmin.nic.in/press_room/2006/PressDebtRep06E.pdf
} 
percent of GDP across 1993-96 to 2.53 percent in 2000-03.59 This deterioration was greater than the worsening in overall fiscal deficits for the same period $(2.55$ percent to 4.07 percent), reflecting the crowding out of capital expenditures by current expenditures such as subsides and salary payments. The spillover from the pay commission's award led to a very large jump in the states' wage bills, and liquidity problems for state governments, which even had difficulty in paying those bills (World Bank, 2005, Box 1.1). The states' total primary deficit also worsened significantly, from an average of 0.69 percent of GDP over 1993-96 to 1.41 percent over 2000-03. The latest estimates for the revenue deficit (1.4 percent in 2004-05 and budgeted at 0.7 percent in 2005-06) reflect an improvement, but it is too early to confidently identify a trend. ${ }^{60}$ Disaggregating the states' deficits reveals (Table 13) that the source of deterioration has been increases in expenditures such as interest payments, rather than declines in own revenues or transfers from the central government (particularly tax sharing and grants determined by the Finance Commission). Further aspects of changes in expenditure (not shown in Table 13) have been increases in subsidies - with the power sector a major culprit - and a squeeze on Plan expenditure, which ought to be earmarked for capital projects. Some of the negative impact of the power sector's problems also shows up in the decline in net nontax revenues (Table 13 and Rao, 2004).

The fiscal performance of individual states has varied considerably. In many cases, the fiscal deterioration for the special category states was worse than that of the major states, but we focus on the latter here, as they contain the bulk of India's population. Data for 15 general category states is shown in Table 14.61 Ranks are shown in parentheses, with a higher rank indicating a 'worse' number in terms of deficit, change in deficit, or debt stock. There is no clear pattern across states in fiscal positions or level of deterioration. High and low income states, reforming states as well as those that have moved slowly on reform, larger and smaller states, all have shown significant fiscal deterioration. The correlation between revenue deficits in the earlier and later periods was 0.35, and the correlation between the revenue deficits in the earlier period and their changes was in fact negative (-0.37). The corresponding correlations for fiscal deficits were 0.67 and -0.11 . The 2004-05 figures, in the last column of the Table, suggest that

\footnotetext{
59 These and other figures in this section are taken from the report of the Twelfth Finance Commission (Twelfth Finance Commission, 2004). The discussion here draws heavily on Singh (2006).

60 These figures are from the Economic Survey of India, 2005-06, available at http://indiabudget.nic.in/es2005-06/chapt2006/chap29.pdf. The improvement in the fiscal deficit, $4.0 \%$ in 2004-05 and 3.4\% in 2005-06 has been smaller, and the debt-GDP ratio has climbed to 33\%, though it may stabilize soon.

${ }^{61}$ Following the analysis in the Twelfth Finance Commission Report, the new states of Chhattisgarh, Jharkand and Uttaranchal are combined with their respective 'parents' for the purposes of the comparison across the years. The 2004-05 figures do not include these new states within Madhya Pradesh, Bihar and Uttar Pradesh, so are not strictly comparable. See the note to Table 14.
} 
this superficial lack of pattern in fiscal performance continued, ${ }^{62}$ though some analyses suggest that deficits have been correlated with political variables (Khemani, 2006b). ${ }^{63}$

Table 15 does indicate some of the underlying sources of states' differing performance. Table 15 again ranks from 'worst' to 'best', with 'worst' being low tax revenue or revenue increases, but high expenditure or expenditure increases. This characterization neglects the potential benefits of government expenditure, ${ }^{64}$ focusing only on the narrow fiscal consequences. Bearing out the earlier aggregate figures (Table 13), we see that, while a couple of states have allowed own-tax revenues to slip substantially, the major source of fiscal deterioration has been increases in expenditures running well beyond tax revenues. The correlation between the own-tax and expenditure ratios fell from -0.13 in the earlier period to -0.41 in the later period, with the negative coefficients indicating, perhaps surprisingly, that higher spending states tended to do worse in own revenue-raising. Again, there is no obvious or simple link between the economic characteristics of the states and their relative revenue and expenditure performance. However, we can consider various institutional contributors to the states' current situation.

Institutional responses to the severe deterioration of the states' fiscal positions were described in Section 1.2, in the context of formal institutional changes in budgetary autonomy. The earlier reliance on internal hierarchical controls through political parties and the bureaucracy was no longer effective. The RBI has continued to be a major institutional player in enforcing fiscal discipline, but with new constraints on its role, as state governments have exercised greater freedom in policymaking and spending. Initial attempts by the center to impose fiscal discipline ran into problems of credibility. These included "contracts," in the nature of MOUs, with fiscal reforms to be exchanged for ways and means advances on transfers due to the states, and a portion of central-state transfers being made conditional on fiscal reforms.

The latest approach to institutional reform seems to have worked better in moving toward fiscal discipline, by commitment to explicit targets for deficit reduction through fiscal responsibility legislation. The central government and many state governments have passed such legislation. The Twelfth Finance Commission recommended pushing the remaining states toward this commitment by tying debt relief to their passage and implementation of fiscal responsibility laws. The commission even recommended minimum provisions for state level legislation. ${ }^{65}$ Preliminary analyses of the impact of

\footnotetext{
62 Budget estimates for 2005-06 indicate significant fiscal improvement for Maharashtra and Gujarat, and somewhat for Madhya Pradesh and Orissa, but not for other states. In fact, Andhra Pradesh, Haryana and West Bengal project large increases in fiscal deficits (RBI, 2006, Table VII). This further illustrates the unpredictability of states' deficits from year to year, in terms of any simple observable characteristic.

63 See also Purfield (2003) for a different regression analysis approach that looks at contagion from the center and various structural variables. In general, the variation in the data suggests that further analysis is required to reach any robust conclusions.

64 In fact, as pointed out in the Twelfth Finance Commission Report, revenue expenditure has tended to crowd out capital expenditure, suggesting that the quality of expenditure has declined over this period.

65 The commission developed an elaborate scheme for restructuring the states' existing debt. Writing off debt and/or rescheduling it does create moral hazard -blunting incentives to change the behavior that led to
} 
such laws suggest that they have had positive impacts on states' fiscal positions, though both the early passage of legislation and positive fiscal outcomes may be joint outcomes of political consensus in those states. In any case, fiscal responsibility laws promote greater transparency and easier monitoring, though the latter may still require new institutional arrangements (Section 1.2 gives some options). Expenditure on salaries, which we have identified as a major contributor to growing fiscal deficits, has also been constrained by the new fiscal responsibility laws.

Despite the usefulness of fiscal responsibility laws, they do not tackle the fundamental underlying incentive problems that can lead to poor fiscal decision-making by subnational governments: for example, their effectiveness would rely on states not being bailed out by the center. Therefore, the proposals to move state governments toward a market-disciplined borrowing regime, as discussed in Section 1.6, will be crucial for long run fiscal discipline. Even here, bailouts by the center remain a possibility, but they will be more transparent, and have more serious reputational consequences. The Finance Commission has recommended overall limits on borrowing by each state, and if these can be enforced effectively (by limiting off-budget borrowing in particular), they will help achieve fiscal discipline. Areas that remain relatively untouched, in legislation and recommendations implemented so far, are the use of captive financing such as small savings and pension funds, and the incentive problems built into the current center-state transfer system.

With respect to local government finances, review of pre-reform data and case studies (Rao and Singh, 2003) indicates that local governments, particularly urban bodies, already faced significant fiscal problems by the 1980s, even before such problems became apparent at the state level, and well before local government reforms. Contributing factors were the lack of transparency, soft budget constraints due to the discretionary nature of local financing, rapid urbanization, and poor budgetary practices. One early view of local government reform (World Bank, 1995) was that formal transfers from the center and states to local governments could accentuate the states' fiscal deficit problems. In fact, one can argue that introducing a formal, rule-governed system has made long-standing local fiscal problems more transparent, and therefore more easily identifiable and soluble. In addition, creditors prefer rule-based to ad hoc transfers, and the long-term goal of building credit markets will be served by these reforms. ${ }^{66}$ While the current situation with respect to local governments seems no worse than the previous one of ad hoc and discretionary transfers and control of local bodies by state governments, the local government fiscal situation remains unsatisfactory in many ways (Sections 1.2 through 1.6), and institutional reforms are still required in several dimensions. Differences in the fiscal situations of the states and local bodies include greater variations across states in local deficits and financing (as noted in Section 1.5, some local

the accumulation of debt in the first place. Conditionalities on debt relief, if credible, can alleviate such moral hazard. However, the commission's specific conditionalities may be too complex, and are potentially inconsistent in places (Rajaraman, 2005). There are also related questions about enforceability. In particular, the poorest highly indebted states may face deficit and debt situations that can only be realistically dealt with by specifically targeted debt relief, beyond what is currently recommended.

66 I am grateful to Jonathan Rodden for this point. 
governments are unable to spend all their budgets, due to institutional constraints), greater variations in per capita expenditures for local governments, and nonstandardization of accounting procedures. The latter makes it difficult, if not impossible, to perform a detailed state-by-state accounting of local government fiscal situations comparable to that in Tables 14 and 15 . However, Table 16 provides a summary of the local government fiscal situation.

\subsection{Service delivery}

Service delivery is poor at all levels of government in India. The problem is more acute at the subnational level because day-to-day and basic services - such as health care, education, water and sanitation - are more the responsibility of subnational tiers, while at the same time these tiers of government have been disadvantaged with respect to fiscal and administrative capacity. Increases in patronage politics and rent-seeking over time have resulted in a decline in the quality of public expenditure. Arguably, those with the greatest distance (social, political or geographical) from the locus of decision-making suffer the most, which suggests that reduction of this distance may be a beneficial direction of reform.

There are several kinds of evidence for the poor quality of service delivery, including tangible public goods and services, as well as various forms of social insurance. One is simply measurement of performance and outcomes, such as educational attainment. A second is evidence based on inputs and processes of government, such as overall spending patterns, and teacher absenteeism. A third is the response of citizens, through exit from the system by use of private alternatives, and their voting behavior.

Measures of state level human development performance provide a first-level indicator of inefficiency, as measured by outcomes, since better-performing states provide a standard against which others can be judged. Table 17 summarizes the outcomes of India's 14 major states in terms of a Human Development Index (HDI) constructed by the Planning Commission (2002). The HDI incorporates eight different dimensions of development performance: per capita expenditure, headcount poverty rate, literacy rate, a formal education enrollment index, infant mortality rate, life expectancy, access to safe water and access to housing constructed with relatively permanent materials. The variation in the HDI across states is not increasing over time, but neither is it the case that gaps are narrowing (Singh et al, 2003). Thus, the 2001 HDI for Gujarat, a high income state, is lower than the 1981 HDI for Kerala. In fact, changes in the HDI for the two states are comparable in absolute terms (though slightly lower as percentages for Kerala), while state government expenditure per capita in Gujarat is almost 40 percent higher. This pairwise comparison is merely one illustration of the relative failure of state governments to deliver on the kinds of public goods and services that affect the HDI. Long run district-level analyses (e.g., Banerjee and Iyer, 2004; Banerjee, Iyer and Somanathan, 2004; Banerjee and Somanathan, 2006 - the period covered in these cases is one where the state governments were primarily responsible for delivery) also show considerable variation in the nature and levels of public goods provided. The main conclusions from these studies are perhaps about political economy and the impact of 
initial conditions, but the variation in outcomes is again a possible indicator of inefficiency in service delivery.

Another performance indicator of inefficiency is the performance of state-level public enterprises, with the State Electricity Boards standing out in this respect. Their large financial losses, while partly the result of poor pricing policies, are strongly indicative of inefficient operations. Finally, poor targeting of expenditures is another indicator of inefficient service delivery. For example, a World Bank (2003a) study concludes that, "The burden of weak administration falls particularly on the poor, who suffer from skewed government spending, limited access to services, and employee indifference."

Second, studies of the functioning of government in India suggest pervasive examples of inefficiency in processes of public service delivery, including the functioning of core administrations, plan and ministry projects, and public sector enterprises. The evidence indicates that for many of the states, subsidies ${ }^{67}$ and salaries are taking a larger and larger share of expenditure, though the states' performance in this respect is not uniform (e.g., Howes and Murgai, 2005) - some state administrations are more efficient than others. There is also evidence that public sector enterprises are also grossly over-staffed. While public sector employees currently enjoy monetary rents or leisure, at least some of the leisure in such inefficient organizations is involuntary, and results in frustration rather than any utility gain. Areas in which administration can be improved include budgeting procedures, accounting and auditing methods, personnel policies and tax collection, among others (Section 1 above; Finance Commission, 2004; World Bank, 2005).

The low efficiency of delivery of health and education in rural areas because of poor performance (absenteeism and low effort) by government employees is also well documented (e.g., Drèze and Gazdar, 1996; PROBE, 1999; World Bank, 2003a, Chapter 3; World Bank, 2006a; Howes and Murgai, 2005; Chaudhury et al, 2006; Kremer et al, 2005). There is substantial evidence that institutional innovations that correct frontline provider incentives or modify the conditions of provision can improve efficiency (e.g., Banerjee et al, 2006; Duflo and Hanna, 2005). There is also evidence is that decentralization of accountability systems can improve incentives if implemented effectively, as in the Madhya Pradesh Education Guarantee Scheme (e.g., Sharma and Gopalakrishnan, 2001; Manor, 2004). Governmental decentralization in this manner is not exclusive of community, private or NGO participation.

The third indicator of inefficiency in public service delivery is private or selfprovision. ${ }^{68}$ This may be natural and acceptable if there are income effects (e.g., private

\footnotetext{
${ }^{67}$ In this context, it has been noted that a system of explicit user charges often allows for more efficient as well as more equitable delivery of services (e.g., drinking water, health and education: see World Bank, 2003a, Chapter 3, as well as World Bank, 2005). This would clearly be a necessary part of a program of reducing inefficient and poorly targeted subsidies.

68 Note that this phenomenon is totally distinct from deliberate public use of private contractors for service delivery or infrastructure provision or maintenance. An excellent treatment of the issues and alternatives in
} 
vs. public transportation) associated with quality of service. Thus, the rich may always choose this route for many quasi-public goods. However, the Indian case is one where the middle class and even the poor rely on costly and inefficient methods ${ }^{69}$ of private provision, because public service delivery is so poor in quality. Household-level generation and storage of electric power and private purchase of water from tankers are two pervasive examples in India. The latter, in particular is often the only route available to the poor for household water supplies.

Poor quality and inefficient delivery of public services in India can, somewhat straightforwardly, be traced to the weak accountability mechanisms operating for individuals (politicians and government employees) and for organizations (ministries and various public sector enterprises). These issues were discussed in Section 2 of this paper. Some of the reforms that can improve service delivery involve strengthening accountability at each level of government, through internal reorganization for better incentive provision, and through greater transparency and more effective monitoring. Weaknesses in accountability can also be traced to the nature of expenditure and revenue assignments across levels of government.

In some respects, all subnational governments in India, state and local, have revenue authority that is weaker than would be dictated by considerations of efficiency or equity. As a result, they rely heavily on transfers from higher level governments. These transfers can be uncertain, and restricted in ways that make their effective use difficult. India's subnational governments, especially at the local level, have problems in (1) exercising statutory authority, (2) administering taxes, and (3) establishing clear tax assignments. The first problem arises partly because of inefficiencies in provision, creating a chicken-and-egg puzzle for improving service delivery. There are also two categories of problems with respect to subnational assignments of expenditure responsibilities (again, particularly at the local level): (1) excessive narrowness, ${ }^{70}$ and (2) lack of clarity. With respect to the latter, concurrency in assignments is a pervasive feature of Indian federalism, and has created problems at all levels of government. Statutory decentralization of responsibilities and authority has not been matched by de facto decision-making control, with decisions often being made by higher-level bureaucrats and politicians.

If the above diagnosis is accurate, then there should be empirical evidence linking decentralization to better public service delivery. The problem in reaching general conclusions in this respect is that decentralization has been varied in its implementation, and by no means optimally designed. Nevertheless, there are some examples to suggest that giving subnational governments more leeway has led to some improvements in service delivery (as well as problems, as in the case of salaries, subsidies and overall

this context for urban water, roads and sanitation is in Deb (1996), Chapter 7. See also Morris (2002), Section 4.3 .

69 The inefficiencies include both the failure to capture scale economies, and negative externalities. Household level water and electric power production exhibit both these problems.

${ }^{70}$ An important, often-neglected aspect of assignment has to do with enforceability (World Bank, 2005), which requires an effective local judiciary. See Rao and Singh (2003) for further discussion. 
fiscal discipline). At the state government level, Tamil Nadu, Andhra Pradesh and Karnataka have made some efforts to improve public infrastructure that would complement and attract private business investment in sectors such as information technology. One can argue that these policies have not provided broad-based service delivery improvements, and certainly not for rural populations in those states. In some cases, the pace of economic development has outstripped the capacity of state and local governments to provide the necessary infrastructure. Nevertheless, one can make the case that mindsets and policymaking processes at the state level have undergone changes that move toward better satisfying constituents. Less controversial cases are those of Madhya Pradesh and Rajasthan, which seemed to have used greater policy-making discretion in the 1990s to improve social outcomes. Thus both of these states showed relative gains in their HDIs in the last decade or two (Table 17).

The evidence is more direct, and somewhat easier to interpret at the local level, since household survey data has been gathered to measure local government performance in several dimensions. While there is no study that performs an explicit "before-andafter" exercise with respect to local government reform, evidence of local responsiveness, targeting and service delivery can be taken as being in favor of decentralization. Perhaps the closest to a "before-and-after" analysis is that of Chaudhuri (2005), who examined a significant exercise to decentralize decision-making beyond legislated assignments. This took place in the state of Kerala, which has a history of decentralization, and scores well on human development indicators (Table 17), especially literacy. Detailed, structured, opinion polls indicated that constituent populations strongly believed that the decentralization had improved service delivery outcomes, though with differences on the extent of improvement. Besley, Pande and Rao (2006a,b) found, for a large sample of rural households in southern India, that decentralized rural participatory democracy improved targeting of welfare programs to the poor, though other kinds of public goods were more subject to interest group effects. Bardhan and Mookherjee (2006b,c), using a 20-year longitudinal survey of West Bengal villages, also found that local government decision-making was associated with reasonably good targeting of public services, rather than any gross form of elite capture.

The examples of well-performing state governments such as Tamil Nadu, and, at the local level, Kerala and West Bengal, may be taken to illustrate the importance of governmental capacity, in addition to the aspects of institutional design that we have discussed throughout this paper. Much of the case for hierarchical control of subnational governments in India has rested on concerns about low local capacity. This argument has also been applied to larger urban bodies (e.g., Bhattacharya, 1972), with a perceived lack of expertise at the local government level. In practice, this was translated into direct control of decision-making, rather than technical assistance coupled with performance monitoring. To some extent, the lack of capacity in India's local governments has been a self-fulfilling expectation, since decision-makers at that level have not been given the opportunity to learn by doing. In that context, the cases of Kerala and West Bengal may stand out as ones where state governments have engaged in substantial efforts at decentralization well before the local government reforms of the $1990 \mathrm{~s},{ }^{71}$ and therefore

71 See Rao and Singh (2003) for further detail and references on the experience of both states. 
they may have been the ones best placed to use decentralization to improve public service delivery. It is well understood that building local capacity in areas such as budgetary management is critical (Finance Commission, 2004, Chapter 8), but there have been problems in getting the states to pursue this objective effectively. In fact, many of the states' own fiscal and expenditure management practices reflect a lack of capacity. Overall, the skills gradient within government often is very steep, from the elite civil service cadres down. Even in the bureaucratic elite specialized financial management skills, such as might be required for market-financed infrastructure projects, are not necessarily strongly present: the emphasis in training tends to be more toward general administration.

\subsection{Corruption and capture}

Aggregate measures suggest that the quality of India's governance is poor along several dimensions, though not out of line with other developing countries, including China - which has a much stronger growth record. However, this does not imply that governance is irrelevant. In particular, corruption adds to the cost of doing business (e.g. Forbes, 2002), and directly affects productivity. Cross-state regressions for India (Dollar et al, 2002) also indicate that the level of harassment, which is typically connected to bribe seeking, directly matter for business productivity. These studies suggest that there is considerable variation across the states in terms of local aspects of corruption. This does not, of course, answer the question of whether corruption has increased with decentralization. Conceptually, the potential problem with decentralization is that it increases the number of levels at which corruption is possible (Shleifer and Vishny, 1993) and intensifies competitive corruption.

The evidence from India suggests that corruption is quite pervasive at all levels of government. In the 2005 Governance Indicators of the World Bank (Kauffman, Kraay and Mastruzzi, 2006), India is in the $47^{\text {th }}$ percentile in "control of corruption," and in the Corruption Perception Index (Transparency International) India is tied for 88th place with countries such as Benin, Mali, and Tanzania. Types of corruption include illegal payments for hiring, job transfers, procurement contracts and provision of public services. Many examples and case studies exist, and we illustrate next.

Wade (1985) documents in detail the system of corruption for state government jobs that involve management of public irrigation facilities. In this case, corruption in hiring and transfers is connected to corruption in the provision of public services. In other cases, there may be corruption in hiring simply because jobs are scarce, and government jobs are particularly attractive in terms of relatively high pay and low demands on performance. Sivaraman (1991) notes that allocating government jobs as a patronage mechanism is an old tradition. A very recent study of the old problem of corruption in allocating driving licenses (Bertrand et al, 2006) uses field experiments to identify the distortions created by corruption. A study by Transparency International (2002) found evidence of "retail corruption" particularly in health care, electric power, police and judiciary functions, taxation and land administration, and education. 
In all these cases, the problems appear to be associated with the organization of administration and the nature of political influence. There is no obvious correlation with the degree of political or administrative decentralization. In fact, in many case, it is lack of local oversight and control that contributes to the problem. In particular, as in the case of pure inefficiency (such as absenteeism or low effort), corruption in service delivery stems from the lack of effective incentives, both internal to government and external. Internal controls exist in theory (see Section 1.2, for example), but are ineffective in practice. Essentially, corruption arises from a failure of accountability, and to the extent that decentralization can improve accountability (Section 2) it may actually control corruption.

In this context, note that accountability is built on transparency, that is, the public availability of information that allows performance and processes ${ }^{72}$ to be measured and evaluated. Thus, transparency can help act as a check on corruption. Information may be self-disclosed, or obtained by monitoring and investigation. Often, though, disclosure of information must be a legal requirement, since the incentive to disclose problems will not exist, and gathering information may be impossible or very costly without legal backing. In the context of rural local government, Bajaj and Sharma (1995) note the problems that can arise, in terms of the information required to assess elected officials:

When village pradhans were entrusted JRY funds for construction of community assets, the village community at large did not have knowledge about the total funds received and the annual expenditure incurred on various projects. The pradhan and the village panchayat officer, who jointly operated the panchayat account, kept the details a closely guarded secret. (p. M-79)

They go on to describe the resolution of the monitoring problem in their example:

[The higher level] government made it mandatory for information to be posted publicly about the works executed, estimated and actual expenditure and savings if any. The displaying of relevant information on bulletin boards in public places and community halls resulted in community pressure on pradhans to account for public funds, and had the effect of many unfinished projects being rapidly completed.

While all cases may not admit such easy fixes, there is no reason why complete information on a broad range of government activities should not be available to all citizens. This remedy is more likely to work in a decentralized context, to the extent that the monitoring tasks are better distributed, and decentralization is more likely to lead to disaggregated budgets that can be parsed by citizens.

Capture is a related problem, but distinct - capture of rents generated in an economy may be a feature of corruption, but can occur through legitimate political and institutional processes. The framers of India's Constitution opted for a relatively centralized, 'quasi-federal' system because of concerns about unity and stability, but also of inequality and local elite capture of resources. ${ }^{73}$ Implicit in this choice was the

\footnotetext{
72 New technologies permit more transparency at all levels of government. See, for example, Halan (2000).

73 B.R. Ambedkar, in 1939, stated, "I confess I have a partiality for a unitary form of government. I think India needs it." He made this statement about local government during the Constituent Assembly's drafting of the constitution: "What is a village but a sink of localism, a den of ignorance, narrow mindedness and communalism...?" See Rao and Singh (2005) for more detail and references.
} 
assumption that the central leadership) politicians and bureaucrats) would be more skilled and more honest than state and local politicians. Analyses of recent decentralization to the local level in India have therefore been particularly concerned with identifying elite capture at the village level. It is arguable that, at the national level, India's political economy has involved competition for rent capture by several key groups, with no single group dominating (Bardhan, 1984). At the state level, political power was initially disproportionately in the hands of the well-educated, and especially the rural elites. The development of India's democracy has included a process of diffusion of power at the state level to lower caste groups that have the advantage of numbers, though not of resources or endowments. ${ }^{74}$

Evidence for capture varies across states. As one might expect, states where caste politics are more salient, and vestiges of feudalism greater, are more subject to local elite capture. For example, Gaiha et al $(1998,2000)$ conclude the following about Uttar Pradesh, based on a qualitative analysis:

A survey of 3 districts in UP on the implementation of the 2 major antipoverty programs, viz. JRY [Jawahar Rozgar Yojana - a centrally sponsored rural development program - since superseded - designed to generate employment through infrastructure creation] and IRDP [Integrated Rural Development Programme - a similar scheme to JRY] in 1997 points to the pervasiveness of rent-seeking behavior in all the Gram Panchayats. As a result, there were largescale diversions of resources. The benefits of JRY, IRDP and the other rural development programs to the poor were minimum. . . Regardless of whether the Panchayat chairperson belonged to upper or lower castes, there was little variation in the method and pattern of domination by the locally powerful groups.

It is probable that similar conclusions can be reached for other states and regions of India that are similar to Uttar Pradesh in social structures and level of development.

On the other hand, there is countervailing evidence for states such as West Bengal that have undertaken some degree of social reform in rural areas. Bardhan and Mookherjee (2006a, b), through a detailed econometric analysis, found that targeting of some publicly funded programs (including provision of private goods such as seed kits) by village level governments did not indicate elite capture - most benefits went to small and marginal farmers. On the other hand, the poorest rural group, landless laborers, was relatively left out of employment generation schemes. In fact, targeting was worse at the level of district governments allocating across villages. As one might expect, greater economic inequality and heterogeneity worsened targeting of programs to the poor, and those programs where transparency was lower were more susceptible to distortion, if not full-scale capture.

Besley, Pande and Rao (2006a, b) and Besley, Pande, Rahman and Rao (2006) also explore political economy factors affecting local government allocation of resources, using data from four southern states (Andhra Pradesh, Karnataka, Kerala and Tamil $\mathrm{Nadu}$ ). Again, there is evidence of political opportunism, but it is not extreme. These studies also develop and test the idea that various institutional design factors can impact

\footnotetext{
74 Béteille (1965) makes an early argument for this process at the local and the state level in Tamil Nadu. CASI (2006) traces the evolution of Bihar politics along these lines.
} 
local allocation: thus effective gram sabhas and local seat reservations for disadvantaged groups help to reduce political opportunism.

Taken together, the studies of rural local government resource allocation in rural India provide indirect, though not direct evidence that accountability mechanisms implemented through decentralization can be effective. There is no direct evidence that a shift from state level to local decision making improves either efficiency or equity. However, the evidence suggests that decentralization does not lead to extreme outcomes of local capture, provided the initial conditions and institutional design are both supportive. Institutional design is directly a policy concern, but even initial conditions can be altered by appropriate interventions, such as local education for capacity building (e.g., Vaddiraju and Mehrotra, 2004). The evidence from West Bengal and southern India indicates that initial conditions can be altered in the long run through state government action, but the newer evidence is based on non-governmental action, and goals of more rapid capacity building.

Capture is less of a concern in urban areas, though the distribution of benefits can favor certain groups or income classes. Areas of corruption in urban local government include retail corruption in service delivery (e.g., having to pay a bribe to receive any service, or to avoid inordinate service lags), tax administration, and, unsurprisingly, in procurement for current expenditures as well as capital projects. While, given the nature of corruption, it is difficult to document its extent, all the evidence suggests that it is pervasive, despite ostensibly strict hierarchical controls such as requiring approvals from higher levels for relatively small expenditures (Rao and Singh, 2003). In the case of urban retail corruption, media exposure and citizen collective action have jointly led to reduction in some cases, e.g., the use of citizen report cards in Bangalore (Paul, 2002, 2006). At the state level, corruption in procurement is worse than at the national level (World Bank, 2003b), but some states are much better than others in this regard, and states such as Karnataka and Tamil Nadu have passed legislation requiring transparency in public procurement. Processes of negotiation for contracts are particularly nontransparent and subject to corruption. These are problems of administrative design (e.g., Morris, 2003, Section 4.2), and not necessarily associated with decentralization of government to subnational levels. The real issue is capacity to monitor bureaucratic processes to identify corruption.

\section{The Way Forward}

Subnational decentralization in India is a political reality, and the pressing issue is not whether it has been a positive development, but how to reform policies and institutions to maximize the benefits, and minimize any harmful consequences, of political and economic decentralization. The objectives of such reform can be encapsulated as (1) improving governmental efficiency with respect to taxes and expenditures, (2) maintaining some degree of equity through and within the operations of the government, and (3) providing some sustainability and stability. 


\subsection{Political Reform}

We begin with political reform. At the state level, there have been calls for introducing reservations for women in legislatures (mirroring what was incorporated in constitutional amendments for local government strengthening). One could also discuss the merits of other reforms of the electoral system, such as proportional representation and candidate qualifications (e.g., to control criminality among elected officials). Here we do not tackle such issues. There is clearly room for improvement in the conduct of elections. Even more so, further developments in media assessment of state governments' performance may improve electoral accountability. ${ }^{75}$ The practice of ranking how the states are doing in providing quality of life for (at least a subset of) their constituents represents an example of a positive development in improving electoral accountability.

At the local level, the mandating of regular local elections through the constitutional amendments has been a major step forward in local accountability, adding voice as an accountability mechanism for the first time. Clearly, some states need to be nudged to follow the law in holding elections, and effective monitoring of these elections also needs to take place. ${ }^{76}$ The scale of the task is enormous, and making sure that resources are available for properly conducting local elections is an important concern. The national government and the courts have a key role to play in this respect. A related issue at the national and state level is that of legislative organization and functioning. The quality of India's parliamentary institutions has been criticized, and some reform here may also be useful.

Going beyond electoral and legislative institutions, since issues of tax and expenditure reform and controlling fiscal deficits require some coordination between the center and the states, institutions such as the ISC may have a greater role to play than in the past. While states that are pivotal, and hence politically powerful in a coalition government at the center, may be able to directly extract concessions from the central government, this does not make the ISC redundant. The potential role of the ISC is precisely to provide an alternative to such ad hoc bargaining. Bargaining over durable changes in rules governing the federation is also quite different from bargaining over specific instances. ${ }^{77}$ For example, the ISC was an important forum for gaining acceptance of the change in tax sharing recommended by the Tenth Finance Commission. ${ }^{78}$ Tax reform, changes in the way that states borrow, and regulation of sectors such as power are

\footnotetext{
75 Majumdar, Mani and Mukand (2003) find theoretical and empirical justification for the idea that better informed voters are able to obtain better performance from government. See also Keefer and Khemani (2003, 2005).

76 There may also be a case for changing the law, so that state level legislators are no longer able to hold posts in the upper tiers of rural local government. However, this is unlikely to be politically feasible - the inclusion of this provision was undoubtedly to enable state level elected officials to protect their local patronage powers.

77 This is an extension of Riker's instrumentalist view of federalism (Riker, 1975, pp. 113-114), to include bargaining not just in constitution making, but also in evolution of subsequent governance, and not just for territorial protection or gain, but also over splitting the economic pie.

${ }^{78}$ More recently, it has also been a place where an important change in the rules governing inter-state water disputes has been approved by the states (Richards and Singh, 2002). See also Kapur (2005) for additional examples.
} 
all areas where the ISC can provide a less public, more focused forum for bargaining over such issues than is possible in Parliament. The role of the ISC may also be expanded if the current process of planning is reformed. The NDC now serves as the bargaining forum for plan transfers and loans: if these were replaced by a dual system of block grants and market-based loans, it would make the NDC redundant.

\subsection{Administrative Reform}

While political reforms, by their nature, can be controversial, there is a strong case for civil service reform, and more generally, bureaucratic reform at every level. Budgeting, expenditure management, accounting and auditing methods, personnel policies and tax administration are all areas where India's governments do not necessarily follow best international practices, and there is ample evidence that improvements can be made. One cannot overemphasize the importance of very basic improvements in government financial management and functioning. ${ }^{79}$ In addition to reforming internal processes, personnel policies would also need to be addressed. Changes in selection and training would probably meet the least resistance. Retrenchment, retirement and promotion policies would no doubt be more difficult to make. Even if there is little progress on changing the personnel make-up of governmental organizations, changing the acquired skills and incentive structures for government employees is a critical reform. At lower levels within any government organization, skill levels and performance incentives are currently particularly lacking. Since hierarchical monitoring has had limitations in the past, especially in the context of increased political interference in dayto-day bureaucratic functioning, accountability must be sought through mechanisms such as greater transparency of processes, and public recording of performance wherever possible.

The subnational component of administrative reform is significant, since some of the greatest problems with respect to organizational capacity and functioning are at the state and local level. At the local level (rural and urban) a new set of decision-makers must be trained to operate effectively in the context of new expenditure responsibilities and revenue authority. Again, training programs are crucial to overcome capacity issues, and these will require funding. It is noteworthy that funds allocated for such tasks are not being spent -this may be a problem of capacity (lack of those who can impart training, or inability of state governments to organize the training) or incentives or both. It is also important for states to consider assigning some of their employees to the local level - this is often difficult, because it can mean a loss of pay or prestige, but it appears to be a natural requirement to accompany decentralization of expenditure assignments. If it cannot be done through reassignment, a longer run shift through attrition at the state level and local government hiring may be more feasible. All these components of administrative reform, including effective decentralization of staff, are critical if decentralization is to fully achieve its potential for improvements in service delivery without increasing waste or corruption.

\footnotetext{
${ }^{79}$ It is noteworthy that the quality of government institutions in India lags so far behind best practice, even after a decade and a half of reform.
} 
The assignment of expenditure responsibilities offers another area for significant reform. While significant responsibilities rest with both state and local governments, a major problem is concurrency of assignment. This is a problem because it leads to lack of clarity in accountability. Numerous illustrations of this exist, especially at the local level (Rao and Singh, 2003). Even within the sphere of local governments, there is too much overlap among the three different tiers (village, block and district). While some degree of concurrency is inevitable, especially when assignments are broadly conceived and specified (e.g., health and education), and constitutional and legislative reassignments may create fresh problems, there is a case for developing some degree of contractual delegation of expenditure responsibilities from higher to lower level governments, so that primary authority for certain kinds of spending is clear. Thus, clarity in expenditure assignments may be sought through improvements in administrative organization within and across levels of government. In some cases of local government assignments, it may well make sense to define subsets of broader areas that are exclusive local responsibilities. It may also make sense to strengthen local authority in areas such as land use and (some facets of) legal enforcement - currently areas where, even after decentralization, states have almost exclusive control. The principles of fiscal equivalence (Olson, 1986) ${ }^{80}$ for subnational authority and of coordination benefits are not always well recognized or implemented in the current subnational expenditure assignments in India.

\subsection{Tax Reform}

Administrative reform and reform of expenditure responsibilities must be complemented by reform of tax assignments. One of the greatest weaknesses of Indian governance is the failure to create links between benefits and costs (the "Wicksellian connection") for taxpayers and other beneficiaries of public expenditure on service delivery (in the latter case, through user charges). The decentralization of tax assignments in practice is effectively much less than that for expenditures, and the current system requires unnecessarily large intergovernmental transfers, which creates an additional set of problems. The current system of tax assignments is unduly restrictive of subnational governments. Several reforms suggest themselves with respect to tax assignments, policy and administration.

First, decentralizing tax assignments will reduce the need for intergovernmental transfers, reducing the adverse incentive effects of such transfers. This issue is taken up later in this section. Land and property taxes can be more clearly assigned to local governments, in cases where state governments have sole or concurrent tax authority, but do not exercise it effectively (as is often the case with land revenue). Local administrative capacity is a potential problem with this decentralization, but one short-run measure is for the state government to continue as a collection agency for some locally-assigned taxes (as opposed to shared taxes). Clearly, complementary reforms of tax administration (DasGupta and Mookherjee, 1998) at the state level are crucial to the success of such a decentralization of assignments. Ultimately, however, it would be necessary to make tax

\footnotetext{
${ }^{80}$ In particular, the idea is that the locus of benefits and of expenditure responsibility should match as well as possible.
} 
administration accountable in some way to local governments to ensure proper collection effort. Improvement in tax administration at all levels of government remains a pressing area for reform, despite being raised repeatedly in high-level policy documents, from the Chelliah committee report in 1991 to the Kelkar committee reports in 2004.

One area where tax assignments have been explicitly centralized pertains to taxation of services. Rao (2000) had suggested moving taxation of services from the Union list, where it implicitly lay (through the Center's residual powers over taxes not explicitly specified in the Constitution), to the Concurrent list via a constitutional amendment. However, the central government chose instead to explicitly add service taxes to the Union List, via the 88th amendment to the Constitution, enacted in January 2004. According to the new institutional regime for service taxes, they are to be shared with the states, in a manner yet to be determined, but by the national parliament, and therefore outside the "common pool" that is divided among the states by the Finance Commission. Indeed, it is possible that the sharing of service taxes will be completely outside the Commission's scope in the future, representing a reversal of previous measures to simplify the tax-sharing system and make it more efficient. Moving assignment of services taxation to the state level is one obvious way to improve the Wicksellian connection.

Second, decentralization must not lead to inefficient tax competition. In fact, even the relatively centralized system of India has suffered from this problem, due to deviation from the constitution's original intent. The framers of the constitution were aware of the need for an internal common market, but included a rather broad escape clause. Article 301 of the Constitution states, "Subject to the other provisions of this part, trade, commerce and intercourse throughout the territory of India shall be free". However, Article 302 empowers Parliament to impose restrictions on this freedom in the "public interest" - a term that is both very broad and not clearly defined in this context. According to Article 286 of the Constitution, "No law of a state shall impose, or authorise the imposition of the tax on the sale or purchase of goods where such sale or purchase takes place (a) outside the state, or (b) in the course of import of goods into, or export of goods out of, the territory of India." However, based on the recommendations of the Taxation Enquiry Commission in 1953, the Sixth Amendment to the Constitution added clauses (2) and (3) to enable the central government to levy taxes on inter-state transactions. The manner of levying inter-state sales taxes led to significant fiscal impediments to free inter-state trade. These issues are being addressed only now, with a comprehensive reform of the sales tax system, and movement to a destination-based VAT system (Rao and Rao, 2006). The problem has been even more severe in some ways at the local level, with the use of "octroi," a local (urban area) goods-entry tax. In some cases, states have replaced octroi with a state-level entry tax, which has similar distortionary effects. At the local level, doing away with octroi requires development of effective urban property tax regimes.

Third, a key tax reform - involving a different aspect of decentralization - that should be considered is to allow lower level governments to piggyback on the central income tax. This allows for efficiencies in collection and tax administration more 
generally, and gives states and local governments the possibility of raising funds at the margin to cover marginal expenditures as determined by constituents of subnational jurisdictions, or their elected representatives. Similarly, local governments can be given the authority to piggyback on state sales taxes. This kind of reform would be a novelty for India, but seems to work quite well in other federal systems (the United States in particular). It differs from the current system of tax sharing or assignment, in giving each level of government autonomy at the margin, rather than having a predetermined exclusive assignment, unclear assignments of similar taxes on similar bases (e.g., excise and sales taxes at the center and state levels), or administratively determined splits of tax revenue where the tax rates are decided entirely by the higher level government. It is entirely possible to impose legal maxima and minima on rates set by lower level governments in such cases of piggybacking, to prevent tax competition from becoming a problem. Services taxation, if not reassigned to the states, could also be a candidate for piggybacking by both state and local governments, since many personal services are local in nature, and the tax bases are relatively immobile.

\subsection{Reform of the Intergovernmental Transfer System}

The intergovernmental transfer system provides the most obvious and perhaps the politically easiest arena for reforms. Possible barriers to reform do include the desire of bureaucrats and politicians to control the disbursement of funds for direct personal gain or for patronage purposes. However, in many cases, the ultimate intended recipients of the funds can provide an effective lobby for reform, if the case is made clearly enough, and if there are no immediate losers. India's intergovernmental transfer system is currently extremely complex and inefficient, as argued in Section 1.5, suggesting that Pareto improvements may be possible. Precedent has been extremely important for some components of this system, yet positive reforms have also been effected in the past. The major change in center-state tax sharing implemented in 2000 went from academic suggestions to finance commission recommendation to political bargaining and passing of a constitutional amendment in about six years.

An important characteristic of the current intergovernmental transfer system is the poor incentives it provides for fiscal discipline by recipient governments. In particular, this has contributed to the fiscal problems of state governments. For the national government, revenue is essentially raised and spent entirely within its jurisdiction, and its performance can be judged by how efficiently these tasks are accomplished. For subnational governments, however, tax-sharing and discretionary categorical grants create significant complications for accountability. A state's total resources depend on the decisions of the center with respect to revenue-raising, and potentially on the spending of the other states as well. This is referred to as a "common pool problem" (e.g. Purfield, 2003; Hausmann and Purfield, 2004). The latter paper picturesquely compares it to what happens when an individual goes to a restaurant in a group and orders lobster, whereas if he were alone, he would have ordered a cheaper item, chicken. However, this analogy oversimplifies, masking the problem and, therefore, the solution. In the example, the implicit assumption is that the bill will be equally divided. Hence the marginal cost of an individual order of lobster is split among the entire group. Suppose instead that the 
marginal cost versus chicken of all the lobster orders is separated out and divided among only those who order lobster. Then the common pool problem goes away. The key idea is that marginal incentives must be right, so that, in the case of India's states, they must bear the full marginal cost of their spending. Singh (2006) calls this, straightforwardly, the "Marginal Principle" of intergovernmental transfers, well known to economists in its general incarnation.

With this "Marginal Principle" in mind, scattered and uneven discussions (e.g., Purfield, 2003) of the common pool problem, transfer dependence, soft budget constraints, and moral hazard can all be examined within a unified conceptual framework. For example, problems of soft budget constraints and moral hazard are just a dynamic version of the Marginal Principle, with the external source of marginal funds coming with a lag, through bailouts by the central government. One caveat should be noted: transfer dependence can still lead to income effects on states' behavior, even when transfers are inframarginal. However, if one objective of transfers is to improve horizontal equity, these income effects may be desirable. Furthermore, they do not, by themselves, create an incentive for fiscal laxity. Having said this, it is possible that the political economy of transfer dependence may make it harder to follow the Marginal Principle, ${ }^{81}$ and this argues for altering tax assignments to substantially reduce transfer dependence, as suggested earlier, in Section 4.3.

One can make a case for the Finance Commission and Planning Commission overhauling their transfer formulae completely, to achieve greater simplicity, transparency and effectiveness with respect to meeting their objectives. The Finance Commission's current methodology is non-transparent in its rationale and its outcomes. To meet horizontal equity objectives, theory would suggest using measures of structure, such as population density, overall size, topography, and levels of economic activity, to establish minimum norms for tax and expenditure levels, which could then be used to determine transfers that would sustain minimum expenditure levels for a state that behaves according to the norm (Rao and Singh, 2005; Bagchi and Chakraborty, 2003). States can then raise and spend money at the margin, without any distortionary effect of transfers. Instead, the Finance Commission uses various criteria in the formula itself, calculating tax shares based on this, without being able to assess if the transfers are adequate or not. To some extent, shortfalls are met through grants, but the use of ad hoc grants based on ex post gaps (after the preliminary devolution is calculated) has the potential to undermine incentives.

The proposed approach is very different from the idea of using the intergovernmental transfer system to provide very refined or targeted incentives to meet

\footnotetext{
${ }^{81}$ Hausmann and Purfield (2004) discuss the possibility that federal systems with large vertical imbalances encourage political bargaining. In fact, one can frame this as an indirect violation of the Marginal Principle, since lobbying behavior affects marginal transfers. Jonathan Rodden (personal communication) has made an important related point: even if the center stops making explicit guarantees, voters and creditors are very likely to continue to perceive implicit ones in a system with such high levels of transfer-dependence. He notes that in other countries, the credit ratings of highly transfer-dependent subnational entities are tightly clustered around the sovereign rating of the higher-level government. Thus, transfer-dependence has a direct impact on expectations of market actors about the likelihood of future bailouts.
} 
general fiscal balance goals. ${ }^{82}$ The key idea is that transfers should not be linked to spending plans or projected resource gaps. This is the best way to respect the Marginal Principle. Once minimum levels of spending (predicated on the states' norms of fiscal effort) are met through these equalizing transfers, the remaining amount of transfers can be determined by pure tax-sharing considerations, based on the states' income shares. Grants based on marginal needs, and any form of categorical grants (which are subject to fungibility anyway) would be done away with in the above restructuring.

With respect to the Planning Commission, there is also a case for overhaul. Planning Commission grants are meant to be for developmental purposes, which might be interpreted as capital spending, although investments in human capital are typically counted as current spending according to budgeting conventions. One can make a case (Singh, 2006) for the Planning Commission restricting itself to certain types of broad categorical grants, and making allocations based on transparent normative criteria, paralleling those proposed for the Finance Commission. The states could be left to choose projects within broad categories. Loan components could be done away with, as recommended by the Twelfth Finance Commission. The Planning Commission could also play a stronger role in designing and coordinating individual ministry schemes, which have otherwise proliferated into a chaotic jumble. The need for better monitoring of the outcomes of all these transfer schemes has been repeatedly expressed, but it is unclear what progress has been made.

An alternative reform would lead to a more radical change in the Planning Commission's role (Singh and Srinivasan, 2006). This would be to reconstitute the Planning Commission as a Fund for Public Investment (FPI) for both the center and states. Its share holders would be the state and central governments. The Fund, much like a multilateral development bank, would appraise the projects proposed to it for their economic and social returns as well as feasibility and soundness of proposed financing (from the center or state's own resources, borrowing from domestic and foreign sources and capital transfers from the center, if relevant). This alternative is considered further in the next section, on subnational borrowing.

With either kind of overhaul of the Planning Commission, it would be useful for the center to come to grips with transfers made by central ministries. Currently, these are poorly designed, coordinated and implemented. Repeated attempts to consolidate various "schemes" have been less than successful. Categorical grants by the center theoretically have a role to play in correcting externalities or promoting national merit goods, but current practice is closer to a disorganized scramble to dispense patronage. Since there is no obvious a priori institutional restriction one can place on transfers that are inherently discretionary, improvements in legislative, administrative and central cabinet review and oversight may be the only solution. Again, the Planning Commission, which has ostensibly been responsible for monitoring, has not been up to the task so far, though in its defense one can argue that the design, proliferation and malleability (old schemes are

82 The current system attempts to combine multiple objectives into overall formulae. Adding complex ways of rewarding fiscal discipline, as in tying some portion of intergovernmental transfers to state-level fiscal reforms, only compounds the problem. 
often rolled into new ones) of these central schemes has made assessment of outcomes difficult.

At the state-local level, to use the term 'reform' with respect to intergovernmental transfers may be misleading, since the process is so new, and is still evolving. Rapid intervention may help to create positive precedents for institutional functioning, and this may be a crucial area for policy education. While each state has constituted at least one State Finance Commission (SFC), and several states are on their third SFC, the quality of these reports is generally poor, as measured both by intellectual and policy-making standards. Many state governments have failed to take their SFC reports seriously, ignoring recommendations when it suits them. Lack of timeliness in all stages of the process has also been a problem. The Twelfth Finance Commission report (Finance Commission, 2004, Chapter 8) details all the problems, and also suggests solutions, though often they are in the nature of exhortations for improved practices.

Concrete measures the states can take include incorporation of guidelines for SFCs into legislation, as a way of committing to the process. Many of the problems flow from the overall poor functioning of the states' political and administrative machinery, and only more effective state level electoral accountability may make a difference there. Better data will improve the functioning of the SFCs, both directly, and through more complete monitoring and benchmarking of their performance. Perhaps the most important catalyst, however, would be giving the states a firmer footing for their own revenues, through reforms of tax assignment and administration, allowing them to address local government needs in a less constrained manner. It can be seen from this discussion, and earlier parts of this section, that reforms along several dimensions are intertwined, and must be implemented in concert for greater success.

\subsection{Reform of subnational borrowing}

Nascent reforms in subnational borrowing mechanisms were described in Section 1.6. In brief, initial attempts to reduce burgeoning state level fiscal deficits involved increasingly sophisticated methods of hierarchical control, using various carrots and sticks. Purely discretionary hierarchical control is unlikely to work, given the complexity of the states' situations, and the ease with which a sovereign national government can use escape clauses to bail out subnational governments. State level fiscal responsibility legislations, following the center's lead, provide more of a commitment device, since the concerned state government can then be publicly held to a measurable standard of fiscal performance. ${ }^{83}$ These methods of managing subnational fiscal performance do not specifically deal with borrowing or borrowing mechanisms, though they can and do include clauses to limit the total debt levels of the borrowing governments. In particular, despite their limitations, both hierarchical and self-imposed legislative limits on subnational borrowing are important in the short and medium run, since alternative fiscal disciplining mechanisms will take time to develop, and will require complementary

83 This public standard-setting feature has been apparent at the national level, where actual and proposed relaxations of FRBM targets have been subject to substantial political and media scrutiny. 
reforms in administration, tax assignments, and the intergovernmental transfer system to be fully effective. ${ }^{84}$

The most important, and direct, reform of borrowing mechanisms involves replacing non-transparent, discretionary subnational borrowing (much like relationship banking) with market-disciplined borrowing (arm's length financing). Ultimately, as we have argued, this is the only way to at least partially respect the Marginal Principle, since borrowing from the central government is subject to a dynamic common pool problem. ${ }^{85}$ As noted in Section 2.3, the functioning of credit markets in India is in its infancy, and trading and rating institutions have to develop, even at the national and corporate levels. One pervasive practice that tends to undermine making market borrowing truly effective as a fiscal disciplining device is the use of guarantees by higher level governments. ${ }^{86}$ However, even with these guarantees, market borrowing is more transparent and efficient than borrowing from higher level governments. The use of development funds (e.g., the Tamil Nadu Urban Development Fund, or TNUDF) as intermediaries for financing infrastructure represents a transitional step towards market borrowing, though much will depend on how these funds operate in practice. ${ }^{87}$ In these cases, transparency and professionalism in lending can be developed as a precursor to fully market-disciplined borrowing from the private sector.

The institutional reforms required for market-based borrowing are many. The previous ad hoc and opaque process of borrowing by the states did not facilitate the development of effective internal processes to allow external assessment of proposed projects. Improvements in financial information, budgeting and accounting practices, regulatory norms and monitoring are all required here, as well as changes in the institutional rules (IMF, 2003; Hausmann and Purfield, 2004). These reforms parallel

84 These complementary reforms have been discussed in other sections of this paper. I am grateful to Jonathan Rodden for emphasizing this perspective. The need for coordinated reforms also bears on World Bank plans to lend to subnational units in India without explicit central government guarantees. For this to be successful, building institutional and fiscal capacity at the subnational level may be a prerequisite. See Chakraborty and Rao (2006) for a cautionary analysis of this issue.

85 It is still possible that state governments will require bailouts in extraordinary circumstances, but $a$ priori market discipline can restrict the frequency of such occurrences. The political economy of such bailouts is also made more transparent, as compared to the current system of regular debt rescheduling, write-offs and implicit subsidies. Note that true market discipline will require other sources of borrowing and central government guarantees to be limited, and lenders to also face the test of the market. In particular, as argued earlier, the states must not have easy access to captive sources of finance, including nationalized financial institutions. Thus, fiscal reform is ultimately closely tied to, and dependent on, financial sector reform (Singh and Srinivasan, 2005a, 2005b). As noted earlier, the Twelfth Finance Commission Report also proposes annual ceilings on state borrowing, which would further harden budget constraints. Again, some of the poorest states may require special treatment in terms of central loans, since they may not be able to utilize market borrowing, but they can be identified, rather than the presumption being that all states need to rely on the center for capital funds.

86 In some cases, these guarantees are not explicit, but are still recognized. For example, CRISIL's rating of the long-term debt of the Hyderabad Metropolitan Water Supply and Sewerage Board (HMWSSB) states that it is "based on the strong support the Board receives from the Government of Andhra Pradesh."

${ }^{87}$ Peterson (2003) argues that the TNUDF is a worldwide leader in designing systems to attract new financing sources and introducing instruments that are consistent with a deregulated financial sector and nascent domestic capital market. 
many of those required for India's financial sector as a whole: state governments just happen to have been among the most powerful of those entities taking advantage of poorly functioning credit markets to run up unpaid debts. Reforms that are already under discussion or taking place include statutory or administrative borrowing ceilings, guarantee redemption funds, explicit restructuring and write-offs, and development of market-based borrowing institutions such as auctions conducted by the RBI. The RBI is also exploring the further development of secondary markets for government debt, credit ratings, and methods of regulation and monitoring. In this context, one may reiterate the perspective given earlier, that the proper sequence of development might be national bond markets, then development of state and local project assessment and management, and revenue capacity, with a full-fledged market for subnational borrowing following on these broader and more fundamental reforms.

\section{References}

Ahluwalia, Montek S. (2002a), "State Level Performance under Economic Reforms in India," in A. Krueger, ed., Economic Policy Reforms and the Indian Economy, Chicago: University of Chicago Press.

Aziz, A. (1998), "Income Structure of Rural Local Governments: The Karnataka Experience", in Konrad Adenauer Foundation, Local Government Finances in India, New Delhi: Manohar.

Bagchi, Amaresh and Pinaki Chakraborty (2004), Towards a Rational System of CentreState Revenue Transfers in India: An Exploration, National Institute of Public Finance and Policy, Working Paper 16, April.

Bagchi, Soumen, and Anirban Kundu (2003), Development of Municipal Bond Market in India: Issues Concerning Financing of Urban Infrastructure, Economic and Political Weekly, February 22, 789-796.

Bajaj, J.L., and Rita Sharma (1995), “Improving Government Delivery Systems: Some Issues and Prospects", Economic and Political Weekly, May 27, M73-M80.

Bajpai Nirupam and Jeffrey Sachs (1999), "The Progress of Policy Reform and Variations in Performance at the Sub-National Level in India", Development Discussion Paper No. 730, Harvard Institute for International Development, November.

Banerjee, Abhijit V., Shawn Cole, Esther Duflo and Leigh Linden (2006), Remedying Education: Evidence from Two Randomized Experiments in India, forthcoming Quarterly Journal of Economics.

Banerjee, Abhijit V., and Lakshmi Iyer, (2004), History, Institutions and Economic Performance: The Legacy of Colonial Land Tenure Systems in India, Working Paper, Department of Economics, MIT, October. 
Banerjee, Abhijit V., Lakshmi Iyer, and Rohini Somanathan (2004), History, Social Divisions and Public Goods in Rural India, Working Paper, Department of Economics, MIT, October.

Banerjee, Abhijit V., and Rohini Somanathan (2001), Caste, Community and Collective Action: The Political Economy of Public Good Provision in India, Working Paper, Department of Economics, MIT, September 20.

Banerjee, Abhijit V., and Rohini Somanathan (2006), The Political Economy of Public Goods: Some Evidence from India, Working Paper, Department of Economics, MIT, April 10.

Bardhan, Pranab (1984), The Political Economy of Development in India, Oxford: Basil Blackwell.

Bardhan Pranab and Dilip Mookherjee (2000), Capture and governance at local and national levels, American Economic Review, 135-139 (May).

Bardhan Pranab and Dilip Mookherjee (2006a), Pro-poor targeting and accountability of local governments in West Bengal, Journal of Development Economics, 79, 303- 327

Bardhan Pranab and Dilip Mookherjee (2006b), Ideology Vs. Competition In Redistributive Politics: An Analysis of Land Reforms in West Bengal, Working Paper, Department of Economics, Boston University, January.

Bardhan Pranab and Dilip Mookherjee (2006c), Land Reform, Decentralized Governance and Rural Development in West Bengal, Conference Paper, Stanford Center for International Development Conference on Challenges of Economic Policy Reform in Asia, May 31-June 32006.

Bertrand Marianne, Simeon Djankov, Rema Hanna, and Sendhil Mullainathan (2006), Does Corruption Produce Unsafe Drivers? Working Paper 12274, National Bureau of Economic Research, Cambridge, MA.

Besley, Timothy, Rohini Pande, and Vijayendra Rao (2006a), Political Selection and the Quality of Government: Evidence from South India, London School of Economics, Working Paper.

Besley, Timothy, Rohini Pande, and Vijayendra Rao (2006b), Participatory Democracy in Action: Survey Evidence from South India, London School of Economics, Working Paper.

Besley, Timothy, Rohini Pande, Lupin Rahman and Vijayendra Rao (2006), The Politics of Public Good Provision: Evidence from Indian Local Governments, London School of Economics, Working Paper.

Béteille, André (1965), Caste, Class, and Power: Changing Patterns of Stratification in a Tanjore Village, Berkeley: University of California Press. 
Bhandari, Laveesh, and Bibek Debroy (2006), 'The State of the States: India's Best and the Worst States' India Today, September.

Bhattacharya, Mohit (1972), State Municipal Relations, New Delhi: Indian Institute of Public Administration.

Biswas, R. and S. Marjit (2000), "Political Lobbying and discretionary Finance in India: An Aspect of Regional Political Influence in a Representative Democracy," processed, Center for Studies in social Sciences, Calcutta.

Brass, Paul (1994), The Politics of India since Independence, $2^{\text {nd }}$ edition, New York: Cambridge University Press.

Chakraborty, Pinaki and M. Govinda Rao (2006), Multilateral Adjustment Lending to States: Hastening Fiscal Correction or Softening the Budget Constraint?, Journal of International Trade and Economic Development, 15:3, pp. 335-358.

Chattopadhyay, Raghabendra, and Esther Duflo (2004), Impact of Reservation in Panchayati Raj: Evidence from a Nationwide Randomised Experiment, Economic and Political Weekly, February 28, 979-986.

Chaudhuri, Shubham (2003), What difference does a constitutional amendment make? The 1994 Panchayati Raj Act and the attempt to revitalize rural local government in India, Columbia University, Department of Economics, Working Paper, May.

Chaudhuri, Shubham (2005), Building local democracy: The People's Campaign for Decentralized Planning in the Indian state of Kerala, presentation, South Asia Decentralization Series, The World Bank.

Chaudhuri, Shubham, and Patrick Heller (2003), The Plasticity of Participation: Evidence from a Participatory Governance Experiment Institute for Social and Economic Research and Policy, Columbia University, Working Paper 03-01, January.

Chaudhury, Nazmul, Jeffrey Hammer, Michael Kremer, Karthik Muralidharan and F. Halsey Rogers (2006), Missing in Action: Teacher and Health Worker Absence in Developing Countries, Journal of Economic Perspectives, Winter 2006, Vol. 20(1), pp. 91-116.

Chhibber, Pradeep (1995) "Political Parties, Electoral Competition, Government Expenditures and Economic Reform in India," Journal of Development Studies, Vol. 32, No. 1, October, pp.74-96

Chhibber, Pradeep, Sandeep Shastri and Richard Sisson (2004) "Federal Arrangements and the Provision of Public Goods in India," Asian Survey, Vol. 44, No. 3, May/June, pp. 339-351.

Cao, Yuanzheng, Yingyi Qian, and Barry R. Weingast (1999), From Federalism, Chinese Style, to Privatization, Chinese Style, Economics of Transition, Vol. 7 no. 1: 103-31. 
Das-Gupta, Arindam, and Dilip Mookherjee (1998), Incentives and Institutional Reforms in Tax Enforcement: An Analysis of Developing Country Experience, Delhi: Oxford University Press.

Dasgupta, Sugato, Amrita Dhillon and Bhaskar Dutta (2001), "Electoral Goals and Center-State Transfers in India”, processed, Indian Statistical Institute, New Delhi.

Dash, Gokulananda (1988), Municipal Finance in India: Based on Orissa, New Delhi: Concept Publishing.

Datta, Abhijit (1992), "Local Government Finances: Trends, Issues and Reforms", in State Finances in India, ed., Amaresh Bagchi, J.L. Bajaj, and William A. Byrd, New Delhi: Vikas Publishing House.

de Zwart, Frank (1994), The Bureaucratic Merry-Go-Round: Manipulating the Transfer of Indian Civil Servants, Amsterdam: Amsterdam University Press.

Deb, Sandipan (ed.) (1996), The India Infrastructure Report: Policy Imperatives for Growth and Welfare, Volumes I-III, New Delhi: National Council of Applied Economic Research.

Debroy, Bibek and Bhandari, Laveesh (2005), Economic Freedom for states of India, Research Report, Rajiv Gandhi Institute for Contemporary Studies, New Delhi, December.

Dillinger, William (1994), Decentralization and Its Implications for Urban Service Delivery, UNDP/UNCHS/World Bank Urban Management Programme Discussion Paper, UMP 16.

Dollar, David, Giuseppe Iarossi and Taye Mengistae (2002), "Investment Climate and Economic Performance: Some Firm Level Evidence from India”, paper presented at $3^{\text {rd }}$ annual Stanford Conference on Indian Economic Reform

Downs, Anthony (1957), An Economic Theory of Democracy, New York: HarperCollins.

Drèze, Jean, and Harris Gazdar (1996), "Uttar Pradesh: The Burden of Inertia," in Indian Development: Selected Regional Perspectives, ed. by Jean Drèze and Amartya Sen (Oxford and Delhi: Oxford University Press).

Duflo, Esther, and Rema Hanna (2005), Monitoring Works: Getting Teachers to Come to School, NBER Working Paper No. W11880, December.

Dutta, Bhaskar (1996), Coalition Governments and Policy Distortions: The Indian Experience, working paper, Indian Statistical Institute, New Delhi.

Dutta, Bhaskar (2000), "Fragmented Legislatures and Electoral Systems: The Indian Experience," in Satu Kahkonen and Anthony Lanyi (eds.), Institutions, Incentives, and Economic Reforms in India, Sage Publications, pp. 77-100. 
Finance Commission (2004), Report of the Twelfth Finance Commission (2005-10), November, http://fincomindia.nic.in/Report of 12th Finance Commission/index.html

Forbes, Naushad (2002), Doing Business in India: What has Liberalization Changed?, in Economic Policy Reforms and the Indian Economy, ed., Anne O. Krueger, Chicago: University of Chicago Press.

Gaiha, Raghav, P.D. Kaushik, and Vani Kulkarni (1998), Jawahar Rozgar Yojana, Panchayats, and the Rural Poor, Asian Survey, 38 (10), pp. 928-949.

Gaiha, Raghav, P.D. Kaushik, and Vani Kulkarni (2000), Participation or Empowerment of the Rural Poor: The Case of Panchayats in India, in Post Colonial India: History, Politics and Culture, eds., Vinita Damodaran, and Maya Unnithan-Kumar, Delhi: Manohar Publications.

Halan, Monika (2000), "Ungreasing Palms in India: An anticorruption crusader discovers the Internet cuts bureaucracy and bribes", www.thestandard.com/article/display/ 0,1151,15851,00.html, June 12 .

Hausmann, Ricardo, and Catriona M. Purfield, 2005, "The Challenge of Fiscal Adjustment in a Democracy: The Case of India," A Sustainable Fiscal Policy for India: An International Perspective, Peter Heller and M. Govinda Rao, ed., Oxford University Press

Howes, Stephen (2005), Reforms to India's Federal Transfer and Borrowing Regime Proposed by the Twelfth Finance Commission: what will they mean for the states? presentation at Conference on 'Fiscal Responsibility and Intergovernmental Finance' June 22-24, Hyderabad, http://siteresources.worldbank.org/INTINDIA/Resources/Stephen.pdf.

Howes, Stephen, Ashok K. Lahiri and Nicholas Stern (2003), eds., State-level reforms in India: towards more effective government, New Delhi: Macmillan India.

Howes, Stephen, and Rinku Murgai, 2005, "Subsidies And Salaries: Issues in the Restructuring of Government Expenditure in India," A Sustainable Fiscal Policy for India: An International Perspective, Peter Heller and M. Govinda Rao, ed., Oxford University Press

Hirschman, Albert O. (1970), Exit, Voice, and Loyalty; Responses to Decline in Firms, Organizations, and States, Cambridge, MA: Harvard University Press.

International Monetary Fund (2003), India: Country Report 03/261, August.

Jha, Saumitra, Vijayendra Rao and Michael Woolcock (2005), Governance in the Gullies: Democratic Responsiveness and Leadership in Delhi's Slums, World Bank Policy Research Working Paper 3694, September. 
Jin, Hehui, Yingyi Qian, and Barry R. Weingast (2005), Regional decentralization and fiscal incentives: Federalism, Chinese style, Journal of Public Economics, 89, 17191742.

Kapur, Devesh (2005) “The Role of India's Institutions in Explaining Democratic Durability and Economic Performance," in Kapur and Mehta (2005).

Kapur, Devesh and Pratap Bhanu Mehta (2005), eds., Public Institutions in India: Performance and Design, New Delhi, Oxford University Press.

Kapur, Devesh and Pratap Bhanu Mehta (2006), “The Indian Parliament as an Institution of Accountability," Democracy, Governance and Human Rights Programme Paper Number 23, United Nations Research Institute for Social Development, January.

Kauffman, Daniel, Aart Kraay and Massimo Mastruzzi (2006), Governance Matters V: Aggregate and Individual Governance Indicators for 1996-2005, The World Bank, September.

Keefer, Philip and Stuti Khemani (2003), Why do the poor receive poor services? discussion paper, Development Research Group, The World Bank, December 2.

Keefer, Philip and Stuti Khemani (2003), Democracy, Public Expenditures and the Poor: Understanding Political Incentives for Providing Public Services, World Bank Research Observer, Vol. 20, No. 1, pp. 1-27.

Khemani, Stuti (2001), Decentralization and Accountability: Are Voters More Vigilant in Local than in National Elections?, Policy Research Working Paper 2557, The World Bank, February.

Khemani, Stuti (2004), "Political cycles in a developing economy: effect of elections in the Indian states." Journal of Development Economics, February, 73 (1), pp. 125-154.

Khemani, Stuti (2006a), Does Delegation of Fiscal Policy to an Independent Agency Make a Difference? Evidence from intergovernmental transfers in India, Working Paper, World Bank, Washington, DC.

Khemani, Stuti (2006b), Party Politics and Fiscal Discipline in a Federation: Evidence from the states of India, forthcoming, Comparative Political Studies.

Kochar, Anjini, Kesar Simngh and Sukhwinder Singh (2006), Targeting Public Goods to the Poor in a Segregated Economy: An Empirical Analysis of Central Mandates in Rural India, working paper, Stanford University, October.

Kohli, Atul, (1990), Democracy and Discontent: India's Growing Crisis of Governability New York: Cambridge University Press. 
Kremer, Michael, Nazmul Chaudhury, F. Halsey Rogers, Karthik Muralidharan and Jeffrey Hammer (2005), Teacher Absence in India: A Snapshot, Journal of the European Economic Association April/May, Vol. 3, No. 2-3, Pages 658-667.

Kundu, Amitabh (2001), Politics and Economics of Credit Rating, Economic and Political Weekly, January 27.

Lall, Somik, and Sanjoy Chakravorty (2003), Economic Geography of Industry Location in India, Paper prepared for the UNU/WIDER Project Conference on Spatial Inequality in Asia, United Nations University Centre, Tokyo, 28-29 March.

Lipset, Seymour Martin (1960), Political Man. Baltimore: Johns Hopkins University Press.

Litvack, Jennie, and Jessica Seddon (eds.) (1999), "Decentralization Briefing Notes”, World Bank Institute Working Paper, Washington, DC: World Bank.

Litvack, Jennie, Junaid Ahmed and Richard Bird (1998), "Rethinking Decentralization at the World Bank”, PRMPS Discussion Paper, Washington, DC: World Bank.

Majumdar, Sumon, Anandi Mani, and Sharun Mukand (2003), Politics, Information And The Urban Bias, Working Paper, Queen's University, Kingston, Ontario, Canada.

Manor, James (2004), The Congress defeat in Madhya Pradesh, Seminar, Vol. 534, February.

Mathew, P. M. (2004), Panchayati Raj and Rural Governance: Who Cares for Economics?, Economic and Political Weekly, April 3-10.

Mookherjee, Dilip (1997), "Incentive Reforms in Developing Country Bureaucracies: Lessons from Tax Administration”, paper presented at Annual World Bank Conference on Development Economics, Washington, D.C., April 30 and May 1.

Morris, Sebastian, ed. (2002), India Infrastructure Report 2002: Governance Issues for Commercialization, New Delhi: Oxford University Press.

Morris, Sebastian, ed. (2003), India Infrastructure Report 2003: Public Expenditure Allocation and Accountability, New Delhi: Oxford University Press.

Munshi, Kaivan, and Mark Rosenzweig (2005), Why is Mobility in India so Low? Social Insurance, Inequality, and Growth, Working Paper, Brown University and Harvard University, July.

Naipaul, V.S. (1975), India: A Wounded Civilization, New York: Alfred Knopf.

National Council of Applied Economic Research (1997), India's Infrastructure: Investment Opportunities, Report, SE010007, May. 
National Productivity Council (2004), State Competitiveness Report, New Delhi.

Oman, Charles (2000), Policy Competition for Foreign Direct Investment - A Study of Competition among Governments to Attract FDI, Development Centre of the OECD, Paris, France.

Oliveira, Jesus, (2001) Economic Effects of Origin and Destination Principle for ValueAdded Taxes, working paper, School of Business and Public Management George Washington University, April.

Olson, M. (1986), "Toward a More General Theory of Governmental Structure", American Economic Review, May.

Pande, Rohini (2003), Can Mandated Political Representation Increase Policy Influence for Disadvantaged Minorities? Theory and Evidence from India, BREAD Working Paper No. 024, April.

Patil, R.H. (2001), Broadbasing and Deepening the Bond Market in India, Wharton Financial Institutions Center Paper, 01-32

Paul, Samuel (2002), Holding the State to Account: Citizen Monitoring in Action, Bangalore: Books for Change.

Paul, Samuel (2006), Public Spending, Outcomes, and Accountability: Citizen Report Card as a Catalyst for Public Action, Economic and Political Weekly, January 28, pp. 333-340.

Peterson, George E. (1998), Measuring Local Government Credit Risk and Improving Creditworthiness, paper prepared for World Bank, March.

Peterson, George E. (2003), "Banks or Bonds? Building a Municipal Credit Market," Project Report, Economics and Research Department, Asian Development Bank.

Planning Commission (2002), National Human Development Report, New Delhi: Government of India.

Pradhan, Hemanta K. (2003), "Local Government Finance and Bond Markets: India," Project Report, Economics and Research Department, Asian Development Bank.

PRIA (2005a), “A Background Paper for Seminar on Status of State Finance Commissions," Participatory Research in Action, November.

PRIA (2005b), "National Seminar on Status of State Finance Commissions: Final Report," Participatory Research in Action, December.

PROBE Team (1999), in association with Center for Development Economics, Public Report on Basic Education in India, New Delhi: Oxford University Press. 
Purfield, Catriona (2003), "The Decentralization Dilemma in India,” IMF Working Paper, Washington: International Monetary Fund.

Rajaraman, Indira (2001), "Growth-Accelerating Fiscal Devolution to the Third Tier", paper presented at NIPFP-DFID-World Bank conference on India: Fiscal Policies to Accelerate Economic Growth, New Delhi, May.

Rajaraman, Indira (2005), "Intergovernmental Finance and Policy Coordination: Implications of the Report of the Twelfth Finance Commission", presentation at Conference on 'Fiscal Responsibility and Intergovernmental Finance' - June 22-24, Hyderabad, http://siteresources.worldbank.org/INTINDIA/Resources/IndiraRajaramanppt.pdf.

Rao, M. Govinda (1979), "Ideological Factors, Political Stability and Tax Revenue Determination: A Case Study of Four Indian States" Public Finance/Finances Publiques, Vol. XXXIV, No. 1, 114-127.

Rao, M. Govinda (1981), Political Economy of Tax and Expenditure Determination in Indian States, New Delhi: Allied Publishers.

Rao, M. Govinda (2000a), "Tax Reform in India: Achievements and Challenges", AsiaPacific Development Journal, 7, 2, 59-74.

Rao, M. Govinda (2004), "State Level Fiscal Reforms in India", in India's Emerging Economy: Performance and Prospects in the 1990's and Beyond, ed. K. Basu, MIT Press, pp. 115-149.

Rao, M. Govinda and Kavita Rao (2006), Trends and Issues in Tax Policy and Reform in India, paper presented at Brookings-NCAER conference on India, March 2006.

Rao, M. Govinda, Ric Shand and K.P. Kalirajan (1999), “Convergence of Incomes across Indian States: A Divergent View," Economic and Political Weekly, March 27-April 2.

Rao, M. Govinda, and Nirvikar Singh, (2002), The Political Economy of Center-State Fiscal Transfers in India, Institutional Elements of Tax Design and Reform, ed. John McLaren, Washington DC, World Bank, pp. 69-123.

Rao, M. Govinda, and Nirvikar Singh (2003), How to Think About Local Government Reform in India (with M.G. Rao), in Economic Reform and the Liberalisation of the Indian Economy: Essays in Honour of Richard T. Shand, ed., K.P. Kalirajan. Edward Elgar., pp. 335-390

Rao, M. Govinda, and Nirvikar Singh (2005), The Political Economy of Federalism in India ${ }_{2}$ New Delhi, Oxford University Press.

Rao, M. Govinda, and Francois Vaillancourt (1994), "Inter-State Tax Disharmony in India: A Comparative Perspective", Publius, The Journal of Federalism, Vol. 24 (Fall), pp. 99-114. 
Rao, N. Rajagopala (1986), Municipal Finances in India (Theory and Practice), New Delhi: Inter-India Publications.

Reserve Bank of India (2001), Annual Report 2000-01, RBI: Mumbai.

Reserve Bank of India (2002), Annual Report 2001-02, RBI: Mumbai.

Reserve Bank of India (2003), Annual Report 2002-03, RBI: Mumbai.

Reserve Bank of India (2005), Annual Report 2004-05, RBI: Mumbai.

Reserve Bank of India (2006a), Bulletin, 2004-05, RBI: Mumbai.

Reserve Bank of India (2006b), Annual Report, RBI: Mumbai.

Reserve Bank of India (2006c), Macroeconomic and Monetary Developments, RBI: Mumbai.

Richards, Alan and Nirvikar Singh (2002), "Inter State Water Disputes in India: Institutions and Policies," in International Journal of Water Resources Development, 18, 4, pp. 611-625.

Riker, William (1975), "Federalism," in Handbook of Political Science, Vol. 5, Fred I. Greenstein and Nelson W. Polsby, (eds.), Reading, MA: Addison-Wesley.

Rodden, Jonathan and Steven Wilkinson (2004), The Shifting Political Economy of Redistribution in the Indian Federation, Paper presented at the Annual Meeting of the International Society for New Institutional Economics, Tucson, AZ, September 30October 3.

Rudolph, Lloyd I., and Susanne H. Rudolph, In Pursuit of Lakshmi: The Political Economy of the Indian State (Chicago: University of Chicago Press, 1987);

Saxena, Naresh C. (2005), Improving delivery of programmes through administrative reforms in India, Report to National Advisory Council, Government of India.

Seabright, Paul (1996), “Accountability and Decentralization in Government: An Incomplete Contracts Model”, European Economic Review, 40, 61-89.

Sharma, Amita, and R. Gopalakrishnan (2001), New ways of doing business in government: partnering for primary education, International Review of Administrative Sciences, 67, 287-295.

Shleifer, Andrei, and Robert W. Vishny (1993), The Quarterly Journal of Economics, Vol. 108, No. 3., August, pp. 599-617.

Singh, Nirvikar (2004), Some Economic Consequences of India's Institutions of Governance: A Conceptual Framework, India Review, vol. 3, no. 2, April, pp. 114-146. 
Singh, Nirvikar (2006a), State Finances in India: A Case for Systemic Reform, in, ed., S. Narayan, Documenting Reform: Case Studies from India, New Delhi: Macmillan pp. 5686.

Singh, Nirvikar (2007), Crossing a Chasm: Technologies, Institutions and Policies for Developing a Regional IT Industry, forthcoming in conference volume, ed. V. Baskar and V. Gayathri, New Delhi: Sage Publications

Singh, Nirvikar, Laveesh Bhandari, Aoyu Chen and Aarti Khare (2003), Regional Inequality in India: A Fresh Look, Economic and Political Weekly, 38 (11), pp. 10691073, March 15.

Singh, Nirvikar, and T.N. Srinivasan (2005a), "Indian Federalism, Globalization and Economic Reform," in T.N. Srinivasan and Jessica Wallack, eds., Federalism and Economic Reform: International Perspectives, Cambridge, UK: Cambridge University Press

Singh, Nirvikar, and T.N. Srinivasan (2005b), Fiscal Policy in India: Lessons and Priorities, in A Sustainable Fiscal Policy for India: An International Perspective, Peter Heller and M. Govinda Rao, ed., Oxford University Press, 393-439

Singh, Nirvikar, and T.N. Srinivasan, (2006), Federalism and Economic Development in India: An Assessment, Conference Paper, Stanford Center for International Development Conference on Challenges of Economic Policy Reform in Asia, May 31-June 3 2006, Revised, October.

Singh, Nirvikar and Garima Vasishtha, (2004) Patterns in Centre-State Fiscal Transfers: An Illustrative Analysis, Economic and Political Weekly, November 6, 39 (45), pp. 4897 4903

Sivaraman B. (1991), Bitter Sweet: Governance of India in Transition, New Delhi: Ashish Publishing House.

Transparency International (2002), Corruption in India: An Empirical Study, New Delhi: Transparency International India and ORG-MARG Research Private Ltd.

Vaddiraju, Anil K. and Shagun Mehrotra (2004), Making Panchayats Accountable, Economic and Political Weekly, September 11.

Venkatachalam, Pritha (2005), Innovative Approaches to Municipal Infrastructure Financing: A Case Study on Tamil Nadu, India, Working Paper 05-68, Development Studies Institute, London School of Economics, November.

Wade, Robert (1985), The market for public office: why the Indian state is not better at development, World Development, vol. 13(4), pp. 467-97. 
Wade, Robert (1989) "Politics and Graft: Recruitment, Appointment, and Promotions to Public Office in India," in Peter M. Ward, ed., Corruption, Development and Inequality, London: Routledge, pp.73-109

Wittman, Donald (1973), 'Parties as Utility Maximizers," American Political Science Review, 67, 490-498.

World Bank (1995), India: Recent Economic Developments and Prospects, Washington, D.C.: The World Bank.

World Bank (1997), World Development Report: The State in a Changing World, Washington, D.C.: Oxford University Press for World Bank.

World Bank (2000), Overview of Rural Decentralization in India, Volumes I-III, Washington, DC: World Bank.

World Bank (2003a), India: Sustaining Reform, Reducing Poverty, New Delhi: World Bank and Oxford University Press.

World Bank (2003b), India: Country Procurement Assessment Report, Report No. 27859-IN, December, Washington, DC, World Bank.

World Bank (2004a), Fiscal Decentralization to Rural Governments in India, Washington, DC, World Bank.

World Bank (2004b), India: Urban Finance and Governance Review, Volumes I-II, Energy and Infrastructure Unit, South Asia Region, December.

World Bank (2005), State Fiscal Reforms in India: Progress and Prospects (A World Bank Report), New Delhi: Macmillan India.

World Bank (2006a), India: Inclusive Growth and Service Delivery: Building on India's Success, Development Policy Review, Report No. 34580-IN, Washington, DC: World Bank.

World Bank (2006b), India - Punjab: Note on the Workings of the State Public Financial Management System, Report No. 36327-IN, May, Washington, DC: World Bank.

\section{Acronyms}

AMC: Ahmedabad Municipal Corporation

BJP: Bharatiya Janata Party

CAGI: Comptroller and Auditor General of India

CARE: Credit Analysis and Research, Ltd. 
CRISIL: Credit Rating Information Services of India Limited

DFI: Development Finance Institution

FC: Finance Commission

FDI: Foreign Direct Investment

FRBM: Fiscal Responsibility and Budget Management

HDI: Human Development Index

IAS: Indian Administrative Service

IAAS: Indian Audit and Accounts Service

ICAS: Indian Civil Accounts Service

ICRA: Indian Credit Rating Agency

INC: Indian National Congress

IPS: Indian Police Service

IRS: Indian Revenue Service

ISC: Inter-State Council

IT: Information Technology

MLA: Member of Legislative Assembly

MLC: Member of Legislative Council

MP: Member of Parliament

NCT: National Capital Territory

NDC: National Development Council

NSSF: National Small Savings Fund

PC: Planning Commission

RBI: Reserve Bank of India

SAL: Structural Adjustment Lending

SFC: State Finance Commission 
PLEASE DO NOT QUOTE OR CITE WITHOUT PERMISSION

STP: Software Technology Park

TFP: Total Factor Productivity

TNUDF: Tamil Nadu Urban Development Fund

UT: Union Territory

VAT: Value Added Tax 
Table 1: Basic Characteristics of States

\begin{tabular}{|c|c|c|c|c|c|c|c|c|}
\hline & $\begin{array}{c}\text { Area } \\
\text { (Sq. } \mathbf{K m})\end{array}$ & $\begin{array}{c}\text { Population } \\
\text { (in '000) }\end{array}$ & $\begin{array}{l}\text { Density of } \\
\text { Pop }\end{array}$ & $\begin{array}{c}\text { NSDP } \\
\text { 1999-00 } \\
\text { Rs. } \\
\text { Million }\end{array}$ & $\begin{array}{c}\text { Per capita } \\
\text { NSDP } \\
\text { (1999-00) }\end{array}$ & $\begin{array}{c}\text { Percentage } \\
\text { of Total } \\
\text { Area }\end{array}$ & $\begin{array}{l}\text { Percentage } \\
\text { of Total } \\
\text { population }\end{array}$ & $\begin{array}{c}\text { Percentage } \\
\text { of Total } \\
\text { NSDP }\end{array}$ \\
\hline High Income States & 601800 & 194065 & 322.5 & 4065770 & 22461 & 18.31 & 18.90 & 28.74 \\
\hline Gujarat & 196000 & 50597 & 258.1 & 896060 & 18685 & 5.96 & 4.93 & 6.33 \\
\hline Goa & 3800 & 1344 & 353.7 & 58620 & 44613 & 0.12 & 0.13 & 0.41 \\
\hline Haryana & 44000 & 21083 & 479.2 & 424880 & 21551 & 1.34 & 2.05 & 3.00 \\
\hline Maharashtra & 308000 & 96752 & 314.1 & 2131510 & 22604 & 9.37 & 9.42 & 15.07 \\
\hline Punjab & 50000 & 24289 & 485.8 & 554700 & 23254 & 1.52 & 2.37 & 3.92 \\
\hline Middle Income States & 725000 & 302633 & 417.4 & 4867930 & 17635 & 22.05 & 29.47 & 34.41 \\
\hline Andhra Pradesh & 275000 & 75728 & 275.4 & 1117530 & 14878 & 8.36 & 7.37 & 7.90 \\
\hline Karnataka & 192000 & 52734 & 274.7 & 862980 & 16654 & 5.84 & 5.13 & 6.10 \\
\hline Kerala & 39000 & 31839 & 816.4 & 569260 & 17709 & 1.19 & 3.10 & 4.02 \\
\hline Tamil Nadu & 130000 & 62111 & 477.8 & 1143090 & 18623 & 3.95 & 6.05 & 8.08 \\
\hline West Bengal & 89000 & 80221 & 901.4 & 1175070 & 14874 & 2.71 & 7.81 & 8.31 \\
\hline Low Income States & 1409300 & 458682 & 325.5 & 4022290 & 9013 & 42.87 & 44.66 & 28.44 \\
\hline Bihar & 94000 & 82879 & 881.7 & 383260 & 4813 & 2.86 & 8.07 & 2.71 \\
\hline Chhattisgarh & 135100 & 20796 & 153.9 & 213310 & 10405 & 4.11 & 2.02 & 1.51 \\
\hline Jharkhand & 79700 & 26909 & 337.6 & 232270 & 9223 & 2.42 & 2.62 & 1.64 \\
\hline Madhya Pradesh & 308000 & 60385 & 196.1 & 677780 & 11626 & 9.37 & 5.88 & 4.79 \\
\hline Orissa & 156000 & 36707 & 235.3 & 311950 & 8733 & 4.75 & 3.57 & 2.21 \\
\hline Rajasthan & 342000 & 56473 & 165.1 & 710200 & 13046 & 10.40 & 5.50 & 5.02 \\
\hline Uttaranchal & 53500 & 8480 & 158.5 & na & na & 1.63 & 0.83 & 0.00 \\
\hline Uttar Pradesh & 241000 & 166053 & 689.0 & 1493520 & 9323 & 7.33 & 16.17 & 10.56 \\
\hline General Category States & 2736100 & 955380 & 349.2 & 12955990 & 14476 & 83.23 & 93.02 & 91.59 \\
\hline Special Category States & 540500 & 55182 & 102.1 & 639300 & 12339 & 16.44 & 5.37 & 4.52 \\
\hline Arunachal Pradesh & 84000 & 1091 & 13.0 & 14270 & 13352 & 2.56 & 0.11 & 0.10 \\
\hline Assam & 78000 & 26638 & 341.5 & 2533300 & 9720 & 2.37 & 2.59 & 1.79 \\
\hline Himachal Pradesh & 56000 & 6077 & 108.5 & 106570 & 17786 & 1.70 & 0.59 & 0.75 \\
\hline Jammu \& Kashmir & 222000 & 10070 & 45.4 & 121820 & 12373 & 6.75 & 0.98 & 0.86 \\
\hline Manipur & 22000 & 2389 & 108.6 & 28580 & 12721 & 0.67 & 0.23 & 0.20 \\
\hline Meghalaya & 23000 & 2306 & 100.3 & 29040 & 12063 & 0.70 & 0.22 & 0.21 \\
\hline Mizoram & 21000 & 891 & 42.4 & 12880 & 14909 & 0.64 & 0.09 & 0.09 \\
\hline Nagaland & 17000 & 1989 & 117.0 & 23300 & 12594 & 0.52 & 0.19 & 0.16 \\
\hline Sikkim & 7000 & 540 & 77.1 & 7580 & 14751 & 0.21 & 0.05 & 0.05 \\
\hline Tripura & 10500 & 3191 & 303.9 & 41930 & 13195 & 0.32 & 0.31 & 0.30 \\
\hline All States & 3276600 & 1010562 & 308.4 & 13595290 & 14359 & 99.67 & 98.40 & 96.11 \\
\hline UTs & 10974 & 16453 & 1499.3 & 549870 & 31211 & 0.33 & 1.60 & 3.89 \\
\hline Total & 3287574 & 1027015 & 312.4 & 14145160 & 13778 & 100.00 & 100.00 & 100.00 \\
\hline
\end{tabular}

Source: Rao and Singh, 2005, Table 4.1 
Table 2: Basic Characteristics of Local Governments (14 Major States)

\begin{tabular}{|c|c|c|c|c|c|c|c|c|c|c|}
\hline \multirow{3}{*}{ State } & \multicolumn{3}{|c|}{$\begin{array}{c}\text { Number of rural local } \\
\text { bodies (RLBs) }\end{array}$} & \multicolumn{3}{|c|}{$\begin{array}{c}\text { Population per elected body } \\
\text { (000s) }\end{array}$} & & \multirow{3}{*}{$\begin{array}{c}\text { Area } \\
\text { per } \\
\text { village } \\
\text { LB }\end{array}$} & \multirow{3}{*}{$\begin{array}{c}\text { Number } \\
\text { of } \\
\text { urban } \\
\text { local } \\
\text { bodies }\end{array}$} & \multirow{3}{*}{$\begin{array}{c}\text { Population } \\
\text { per urban } \\
\text { local body } \\
\text { (000s) }\end{array}$} \\
\hline & \multirow[t]{2}{*}{ District } & \multirow[t]{2}{*}{ Block } & \multirow[t]{2}{*}{ Village } & \multirow{2}{*}{$\begin{array}{c}\text { State } \\
\text { assembly }\end{array}$} & \multicolumn{3}{|c|}{ Rural local bodies (RLBs) } & & & \\
\hline & & & & & District & Block & Village & & & \\
\hline Andhra Pradesh & 22 & 1093 & 21784 & 66,508 & 2210.0 & 44.5 & 2.2 & 12 & 116 & 154.2 \\
\hline Bihar & 55 & 726 & 12181 & 86,374 & 1364.0 & 103.3 & 6.2 & 14 & 170 & 66.8 \\
\hline Gujarat & 19 & 184 & 13547 & 41,310 & 1424.4 & 147.1 & 2.0 & 14 & 149 & 95.6 \\
\hline Haryana & 16 & 111 & 5958 & 16,464 & 775.6 & 111.8 & 2.1 & 7 & 82 & 49.4 \\
\hline Karnataka & 27 & 175 & 5673 & 44,977 & 1150.7 & 177.5 & 5.5 & 33 & 215 & 64.7 \\
\hline Kerala & 14 & 152 & 990 & 29,099 & 1529.9 & 140.9 & 21.6 & 36 & 58 & 132.4 \\
\hline Madhya Pradesh & 45 & 459 & 31126 & 66,181 & 1129.8 & 110.8 & 1.6 & 14 & 404 & 38.0 \\
\hline Maharashtra & 29 & 319 & 27611 & 78,937 & 1668.8 & 151.7 & 1.8 & 11 & 244 & 125.2 \\
\hline Orissa & 30 & 314 & 5255 & 31,660 & 914.2 & 87.3 & 5.2 & 29 & 102 & 41.5 \\
\hline Punjab & 17 & 138 & 11591 & 20,282 & 840.5 & 103.5 & 1.2 & 4 & 137 & 43.7 \\
\hline Rajasthan & 32 & 237 & 9184 & 44,006 & 1060.6 & 143.2 & 3.7 & 37 & 183 & 55.0 \\
\hline Tamil Nadu & 28 & 385 & 12593 & 55,859 & 1313.6 & 95.5 & 2.9 & 10 & 744 & 25.6 \\
\hline Uttar Pradesh & 83 & 904 & 58620 & 139,112 & 1343.5 & 123.3 & 1.9 & 5 & 684 & 40.4 \\
\hline West Bengal & 17 & 340 & 3314 & 68,078 & 2904.1 & 145.2 & 14.9 & 26 & 122 & 153.3 \\
\hline India & 499 & 5905 & 232278 & 1259.9 & 106.5 & 2.7 & 13 & 3682 & 59.1 & \\
\hline
\end{tabular}

\begin{tabular}{|c|c|c|c|c|c|c|c|c|c|c|}
\hline & \multicolumn{5}{|c|}{ Number of elected representatives to: } & \multicolumn{5}{|c|}{ Population per elected representative to: } \\
\hline & \multirow[t]{2}{*}{ Parliament } & \multirow{2}{*}{$\begin{array}{c}\text { State } \\
\text { assembly }\end{array}$} & \multicolumn{3}{|c|}{ Rural local bodies } & \multirow[t]{2}{*}{ Parliament } & \multirow{2}{*}{$\begin{array}{c}\text { State } \\
\text { assembly }\end{array}$} & \multicolumn{3}{|c|}{ Rural local bodies } \\
\hline & & & District & Block & Village & & & District & Block & Village \\
\hline Andhra Pradesh & 42 & 294 & 1093 & 14644 & 230529 & $1,583,524$ & 226,218 & 44,484 & 3,320 & 211 \\
\hline Bihar & 54 & 324 & 1585 & 15344 & 165452 & $1,599,527$ & 266,588 & 47,332 & 4,889 & 453 \\
\hline Gujarat & 26 & 182 & 761 & 3814 & 123470 & $1,588,830$ & 226,976 & 35,563 & 7,096 & 219 \\
\hline Haryana & 10 & 90 & 303 & 2418 & 54159 & $1,646,365$ & 182,929 & 40,953 & 5,132 & 229 \\
\hline Karnataka & 28 & 224 & 919 & 3340 & 80627 & $1,606,329$ & 200,791 & 33,808 & 9,302 & 385 \\
\hline Kerala & 20 & 140 & 300 & 1547 & 10270 & $1,454,926$ & 207,847 & 71,394 & 13,845 & 2,086 \\
\hline Madhya Pradesh & 40 & 320 & 946 & 9097 & 474351 & $1,654,529$ & 206,816 & 53,745 & 5,589 & 107 \\
\hline Maharashtra & 48 & 288 & 1762 & 3524 & 303545 & $1,644,525$ & 274,087 & 27,466 & 13,733 & 159 \\
\hline Orissa & 21 & 147 & 854 & 5260 & 81077 & $1,507,606$ & 215,372 & 32,113 & 5,214 & 338 \\
\hline Punjab & 13 & 117 & 274 & 2441 & 87842 & $1,560,151$ & 173,350 & 52,149 & 5,854 & 163 \\
\hline Rajasthan & 25 & 200 & 997 & 5257 & 119419 & $1,760,240$ & 220,030 & 34,041 & 6,456 & 284 \\
\hline Tamil Nadu & 39 & 234 & 648 & 6499 & 97398 & $1,432,281$ & 238,713 & 56,761 & 5,660 & 378 \\
\hline Uttar Pradesh & 85 & 473 & 2551 & 58165 & 682670 & $1,636,615$ & 294,106 & 43,711 & 1,917 & 163 \\
\hline West Bengal & 42 & 294 & 723 & 8579 & 50345 & $1,620,904$ & 231,558 & 68,285 & 5,755 & 981 \\
\hline India & 543 & 4120 & 13484 & 128581 & 2580261 & $1,558,568$ & & & & \\
\hline
\end{tabular}

Source: Chaudhuri (2003)

Note: Figures predate creation of Chhattisgarh, Jharkhand and Uttaranchal 
Table 3

\section{Illustrative List of Developmental Subjects (Other Than Financial Subjects) Included in the Union, State, and Concurrent Lists in the Seventh Schedule of the Constitution}

\begin{tabular}{|c|c|c|}
\hline \multicolumn{3}{|r|}{ (A) Union List } \\
\hline $\begin{array}{ll}\text { S. } \\
\text { No. }\end{array}$ & \begin{tabular}{|l|} 
Entry \\
No.
\end{tabular} & Subject \\
\hline 1 & 6 & Atomic energy and mineral resources necessary for its production \\
\hline 2 & 22 & Railways \\
\hline 3. & 23 & Highways declared by or under law made by Parliament to be national highways \\
\hline 4. & 24 & $\begin{array}{l}\text { Shipping and navigation on inland waterways, declared by Parliament by law to be national waterways, as } \\
\text { regards mechanically propelled vessels the rule of the road on such waterways. }\end{array}$ \\
\hline 5. & 25 & $\begin{array}{l}\text { Maritime shipping and navigation including shipping and navigation on tidal waters provision of } \\
\text { education and training for the mercantile marine and regulation of such education and training provided } \\
\text { by States and other agencies. }\end{array}$ \\
\hline 6. & 26 & Lighthouses, lightships, beacons and other provision for the safety of shipping and aircraft. \\
\hline 7. & 27 & $\begin{array}{l}\text { Ports declared by or under law made by Parliament or existing law to be major ports, including their } \\
\text { delimitation and the constitution and powers of port authorities therein. }\end{array}$ \\
\hline 8. & 28 & Port quarantine, including hospitals connected therewith seamen's and marine hospitals. \\
\hline 9. & 29 & $\begin{array}{l}\text { Airways aircraft and air-navigation provision of aerodromes; regulation and organisation of air traffic and } \\
\text { of aerodromes; provision for aeronautical education and training and regulation of such education and } \\
\text { training provided by States and other agencies. }\end{array}$ \\
\hline 10. & 30 & $\begin{array}{l}\text { Carriage of passengers and goods by railways, sea or air, or by national waterways in mechanically } \\
\text { propelled vessels. }\end{array}$ \\
\hline 11. & 31 & Posts and telegraph: telephones, wireless, broadcasting and other form of communications. \\
\hline 12. & 41 & $\begin{array}{l}\text { Trade and commerce with foreign countries; import and export across customs frontiers; definition of } \\
\text { customs frontiers. }\end{array}$ \\
\hline 13. & 42 & Inter-State trade and commerce. \\
\hline 14. & 52 & $\begin{array}{l}\text { Industries, the control of which by the Union is declared by parliament by law to be expedient in the } \\
\text { public interest. }\end{array}$ \\
\hline 15. & 53 & $\begin{array}{l}\text { Regulation and development of oilfields and mineral oil resources; petroleum and petroleum products; } \\
\text { other liquids and substances declared by Parliament by law to be dangerously inflammable. }\end{array}$ \\
\hline 16. & 54 & $\begin{array}{l}\text { Regulation of mines and mineral development to the extent which such regulation and development under } \\
\text { the control of the Union is declared by Parliament by law to be expedient in the public interest. }\end{array}$ \\
\hline 17. & 56 & $\begin{array}{l}\text { Regulation and development of inter-State rivers and river valleys to the extent to which such regulation } \\
\text { and development under the control of the Union is declared by Parliament by law to be expedient in the } \\
\text { public interest. }\end{array}$ \\
\hline 18. & 57 & Fishing and fisheries beyond territorial waters. \\
\hline 19. & 65 & $\begin{array}{l}\text { Union agenda and institutions for - } \\
\text { a. professional, vocational or technical training including the training of police officers; or } \\
\text { b. the promotion of special studies or research; or } \\
\text { c. scientific or technical assistance in the investigation or detection of crime. }\end{array}$ \\
\hline 20. & 66 & $\begin{array}{l}\text { Coordination and determination of standards in institutions for higher education or research and scientific } \\
\text { and technical institutions. }\end{array}$ \\
\hline 21. & 68 & $\begin{array}{l}\text { Survey of India, the geological, botanical, zoological and anthropological surveys of India, meteorological } \\
\text { organizations. }\end{array}$ \\
\hline
\end{tabular}




\begin{tabular}{|c|c|c|}
\hline \multicolumn{3}{|r|}{ (B) State List } \\
\hline S. No. & Entry No. & Subject \\
\hline 1 & 5 & $\begin{array}{l}\text { Local government, that is to say, the constitution and powers of municipal corporations, } \\
\text { improvements trusts, district boards, mining settlement authorities and other local authorities for } \\
\text { the purpose of local self-government or village administration. }\end{array}$ \\
\hline 2 & 6 & Public health and sanitation; hospitals and dispensaries \\
\hline 3. & 9 & Relief of the disabled and unemployable. \\
\hline 4. & 13 & $\begin{array}{l}\text { Communications, that is to say, roads, bridges, ferries, and other means of communication not } \\
\text { specified in List I: municipal tramways; ropeways; inland waterways and traffic thereon subject } \\
\text { to the provisions of List I and List II with regard to such waterways; vehicles other than } \\
\text { mechanically propelled vehicles. }\end{array}$ \\
\hline 5. & 14 & $\begin{array}{l}\text { Agriculture, including agricultural education and research, protection against pests and } \\
\text { prevention of plant diseases. }\end{array}$ \\
\hline 6. & 15 & $\begin{array}{l}\text { Preservation, protection and improvement of stock and prevention of animal diseases; } \\
\text { veterinary training and practice. }\end{array}$ \\
\hline 7. & 17 & $\begin{array}{l}\text { Water, that is to say, water supplies, irrigation and canals, drainage, embankments, water } \\
\text { storage and water power subject to the provisions of entry } 56 \text { of List I. }\end{array}$ \\
\hline 8. & 18 & $\begin{array}{l}\text { Land, that is to say, rights in or over land, land tenures including the relations of landlord and } \\
\text { tenant, and the collection of rents; transfer and alienation of agricultural land; land improvement } \\
\text { and agricultural loans; colonization. }\end{array}$ \\
\hline 9. & 21 & Fisheries \\
\hline 10. & 23 & $\begin{array}{l}\text { Regulation of mines and mineral development subject to the provisions of List I with respect to } \\
\text { regulation and development under the control of the Union. }\end{array}$ \\
\hline 11. & 24 & Industries subject to the provisions of entries 7 and 52 of List I. \\
\hline 12. & 25 & Gas and gas-works \\
\hline 13. & 26 & Trade and commerce within the State subjects to the provisions of entry 33 of List III. \\
\hline 14. & 27 & Production, supply and distribution of goods subject to the provisions of entry 33 of List III. \\
\hline 15. & 32 & Cooperative societies \\
\hline 16. & 35 & Works, lands and buildings vested in or in the possession of the State. \\
\hline
\end{tabular}




\section{(C) Concurrent List}

\begin{tabular}{|c|c|c|}
\hline S. No. & \begin{tabular}{|l|} 
Entry \\
No.
\end{tabular} & Subject \\
\hline 1 & $17 \mathrm{~A}$ & Forests \\
\hline 2. & 20 & Economic and social planning \\
\hline 3. & $20 \mathrm{~A}$ & Population control and family planning \\
\hline 4. & 23 & Social security and social insurance; employment and unemployment \\
\hline 5. & 25 & $\begin{array}{l}\text { Education, including technical education, medical education and universities, subject to the } \\
\text { provisions of entries } 63,64,65 \text { and } 66 \text { of List I; vocational and technical training of labor. }\end{array}$ \\
\hline 6. & 27 & $\begin{array}{l}\text { Relief and rehabilitation of persons displaced from their original place of residence by reasons of the } \\
\text { setting up of the Dominions of India and Pakistan. }\end{array}$ \\
\hline 7. & 31 & $\begin{array}{l}\text { Ports other than those declared by or under law made by Parliament or existing law to be major } \\
\text { ports. }\end{array}$ \\
\hline 8. & 32 & $\begin{array}{l}\text { Shipping and navigation and inland waterways as regards mechanically propelled vessels, and the } \\
\text { rule of the road on such waterways, and the carriage of passengers and goods on inland waterways } \\
\text { subject to the provisions of List I with regard to national waterways. }\end{array}$ \\
\hline 9. & 33 & $\begin{array}{l}\text { Trade and commerce in, and the production supply and distribution of - } \\
\text { a. the products of any industry where the control of such industry by the Union is } \\
\text { declared by Parliament by law to be expedient in the public interest and imported } \\
\text { goods on inland waterways subject to the provisions of List I with regard to national } \\
\text { waterways. } \\
\text { b. foodstuffs, including edible oilseeds and oils; } \\
\text { c. cattle fodder, including oilseeds and other concentrates; } \\
\text { d. raw cotton, where ginned or unginned and cotton seed; and } \\
\text { e. raw jute. }\end{array}$ \\
\hline 10 . & 36 & Factories \\
\hline 11. & 37 & Boilers \\
\hline 12. & 38 & Electricity \\
\hline
\end{tabular}

Source: Rao and Singh (2005) 


\section{Table 4: Local Government Constitutional Assignments}

\section{Rural Governments: Eleventh Schedule (Article 243G)}

\begin{tabular}{|l|l||}
\hline 1. & Agriculture, including agricultural extension. \\
\hline 2. & Land improvement, implementation of land reforms, land consolidation and soil conservation. \\
\hline 3. & Minor irrigation, water management and watershed development. \\
\hline 4. & Animal husbandry, dairying and poultry. \\
\hline 5. & Fisheries. \\
\hline 6. & Social forestry and farm forestry. \\
\hline 7. & Minor forest produce. \\
\hline 8. & Small scale industries, including food processing industries. \\
\hline 9. & Khadi, village and cottage industries. \\
\hline 10. & Rural housing. \\
\hline 11. & Drinking water. \\
\hline 12. & Fuel and fodder. \\
\hline 13. & Roads, culverts, bridges, ferries, waterways and other means of communication. \\
\hline 14. & Rural electrification, including distribution of electricity. \\
\hline 15. & Non-conventional energy sources. \\
\hline 16. & Poverty alleviation programme. \\
\hline 17. & Education, including primary and secondary schools. \\
\hline 18. & Technical training and vocational education. \\
\hline 19. & Adult and non-formal education. \\
\hline 20. & Libraries. \\
\hline 21. & Cultural activities. \\
\hline 22. & Markets and fairs. \\
\hline 23. & Health and sanitation, including hospitals, primary health centres and dispensaries. \\
\hline 24. & Family welfare. \\
\hline 25. & Women and child development. \\
\hline 26. & Social welfare, including welfare of the handicapped and mentally retarded. \\
\hline 27. & Welfare of the weaker sections, and in particular, of the Scheduled Castes and the Scheduled \\
\hline 28. & Public distribution system. \\
\hline 29. & Maintenance of community assets. \\
\hline & \\
\hline
\end{tabular}


Urban Governments: Twelfth Schedule (Article 243W)

\begin{tabular}{||l|l||}
\hline \hline 1. & Urban planning including town planning. \\
\hline 2. & Regulation of land-use and construction of buildings. \\
\hline 3. & Planning for economic and social development. \\
\hline 4. & Roads and bridges. \\
\hline 6. & Water supply for domestic, industrial and commercial purposes. \\
\hline 7. & Public health, sanitation conservancy and solid waste management. \\
\hline 8. & Fire services. \\
\hline 9. & Urban forestry, protection of the environment and promotion of ecological aspects. \\
\hline 10. & Slum improvement and upgradation. \\
\hline 11. & Urban poverty alleviation. \\
\hline 12. & Provision of urban amenities and facilities such as parks, gardens, playgrounds. \\
\hline 13. & Promotion of cultural, educational and aesthetic aspects. \\
\hline 14. & Burials and burial grounds; cremations, cremation grounds; and electric crematoriums. \\
\hline 15. & Cattle pounds; prevention of cruelty to animals. \\
\hline 16. & Vital statistics including registration of births and deaths. \\
\hline 17. & Public amenities including street lighting, parking lots, bus stops and public conveniences. \\
\hline 18. & Regulation of slaughter houses and tanneries. \\
\hline
\end{tabular}


Table 5: Taxation Heads Assigned to the Union and the States in the Constitution (As Listed in the Seventh Schedule)

\begin{tabular}{|c|c|c|c|}
\hline \multicolumn{2}{|r|}{ Union } & \multicolumn{2}{|r|}{ States } \\
\hline $\begin{array}{l}\text { Entry in List } \\
\text { I of the } \\
\text { Seventh } \\
\text { Schedule }\end{array}$ & Head & $\begin{array}{l}\text { Entry in List } \\
\text { II of the } \\
\text { Seventh } \\
\text { Schedule }\end{array}$ & Head \\
\hline 82 & $\begin{array}{l}\text { Taxes on income other than } \\
\text { agricultural income }\end{array}$ & 45 & $\begin{array}{l}\text { Land revenue, including the assessment } \\
\text { and collection of revenue, the maintenance } \\
\text { of land records, survey for revenue } \\
\text { purposes. }\end{array}$ \\
\hline 83 & $\begin{array}{l}\text { Duties of customs including export } \\
\text { duties }\end{array}$ & 46 & Taxes on agricultural income \\
\hline 84 & $\begin{array}{l}\text { Duties of excise on tobacco and } \\
\text { other goods manufactured or } \\
\text { produced in India except- } \\
\text { a. alcoholic liquors for human } \\
\text { consumption; } \\
\text { b. opium, Indian hemp and other } \\
\text { narcotic drugs and narcotics; } \\
\text { but including medicinal and } \\
\text { toilet preparations containing } \\
\text { alcohol or any substance } \\
\text { included in sub-paragraph (b) } \\
\text { of this entry. }\end{array}$ & 47 & $\begin{array}{l}\text { Duties in respect of succession of } \\
\text { agricultural land }\end{array}$ \\
\hline 85 & Corporation tax & 48 & Estate duty in respect of agricultural land \\
\hline 86 & $\begin{array}{l}\text { Taxes on the capital value of the } \\
\text { assets, exclusive of agricultural } \\
\text { land of individuals and companies; } \\
\text { taxes on the capital of companies }\end{array}$ & 49 & Taxes on lands and buildings \\
\hline 87 & $\begin{array}{l}\text { Estate duty in respect of property } \\
\text { other than agricultural land. }\end{array}$ & 50 & $\begin{array}{l}\text { Taxes on mineral rights subject to any } \\
\text { limitations imposed by Parliament by law } \\
\text { relating to mineral development }\end{array}$ \\
\hline 88 & $\begin{array}{l}\text { Duties in respect of succession to } \\
\text { property other than agricultural } \\
\text { land }\end{array}$ & 51 & $\begin{array}{l}\text { Duties of excise on the following goods } \\
\text { manufactured or produced in the State and } \\
\text { countervailing duties at the same or lower } \\
\text { rates on similar goods manufactured or } \\
\text { produced elsewhere in India: } \\
\text { a. alcohol liquors for human consumption; } \\
\text { b. opium, Indian hemp and other narcotic } \\
\text { drugs and narcotics; but not including } \\
\text { medicinal and toilet preparations } \\
\text { containing alcohol or any substance } \\
\text { included in sub-paragraph (b) of this } \\
\text { entry. }\end{array}$ \\
\hline 89 & $\begin{array}{l}\text { Terminal taxes on goods or } \\
\text { passengers carried by railway, sea } \\
\text { or air: taxes on railway fares and } \\
\text { freights. }\end{array}$ & 52 & $\begin{array}{l}\text { Taxes on the entry of goods into a local } \\
\text { area for consumption, use or sale therein. }\end{array}$ \\
\hline
\end{tabular}


Table 5 (contd.)

\begin{tabular}{|c|c|c|c|}
\hline 90 & $\begin{array}{l}\text { Taxes other than stamp duties on } \\
\text { transactions in stock exchanges and } \\
\text { future markets }\end{array}$ & 53 & Taxes on the consumption or sale of electricity \\
\hline 91 & $\begin{array}{l}\text { Rates of stamp duty in respect of } \\
\text { bills of exchange, cheques, } \\
\text { promissory notes, bills of lading, } \\
\text { letters of credit, policies of } \\
\text { insurance, transfer of shares, } \\
\text { debentures, proxies and receipts. }\end{array}$ & @,54 & $\begin{array}{l}\text { Taxes on the sale or purchase of goods other } \\
\text { than newspapers, subject to the provisions of } \\
\text { entry } 92 \mathrm{~A} \text { of List I. }\end{array}$ \\
\hline 92 & $\begin{array}{l}\text { Taxes on the sale or } \\
\text { purchase of newspapers and on } \\
\text { advertisements published therein. }\end{array}$ & 55 & $\begin{array}{l}\text { Taxes on advertisements other than } \\
\text { advertisements published in the newspaper @@ } \\
\text { and advertisements broadcast by radio or } \\
\text { television. }\end{array}$ \\
\hline$* 92 \mathrm{~A}$ & $\begin{array}{l}\text { Taxes on the sale or } \\
\text { purchase of goods other than } \\
\text { newspapers, where such sale or } \\
\text { purchase takes place in the course of } \\
\text { inter-State trade or commerce. }\end{array}$ & 56 & $\begin{array}{l}\text { Taxes on goods and passengers carried } \\
\text { by road or on inland waterways. }\end{array}$ \\
\hline$* * 92 \mathrm{~B}$ & $\begin{array}{l}\text { Taxes on the consignment } \\
\text { of goods (whether the consignment } \\
\text { is to the person making it or to any } \\
\text { other person), where such } \\
\text { consignment takes place in the } \\
\text { course of inter-State trade or } \\
\text { commerce. }\end{array}$ & 57 & $\begin{array}{l}\text { Taxes on vehicles, whether } \\
\text { mechanically propelled or not, suitable for use } \\
\text { on roads including tramcars, subject to the } \\
\text { provision of entry } 35 \text { of List III. }\end{array}$ \\
\hline \multirow[t]{6}{*}{97} & $\begin{array}{l}\text { Any other matter not } \\
\text { enumerated in List II or List III } \\
\text { including any tax not mentioned in } \\
\text { either or both the Lists. }\end{array}$ & 58 & Taxes on animals and boats \\
\hline & & 59 & Tolls \\
\hline & & 60 & $\begin{array}{l}\text { Taxes on professions, trades, callings and } \\
\text { employments }\end{array}$ \\
\hline & & 61 & Capitation taxes \\
\hline & & 62 & $\begin{array}{l}\text { Taxes on luxuries, including taxes on } \\
\text { entertainments, amusements, betting and } \\
\text { gambling. }\end{array}$ \\
\hline & & 63 & $\begin{array}{l}\text { Rates of stamp duty in respect of documents } \\
\text { other than those specified in the provision of List } \\
\text { I with regard to rates of stamp duty. }\end{array}$ \\
\hline
\end{tabular}

* Ins. by the Constitution (Sixth Amendment) Act, 1956 s.2

** Ins. by the Constitution (Forty-sixth Amendment) Act, 1982, s.5

(a) Sub. by the Constitution (Sixth Amendment) Act 1956, s.2 for entry 54

@@ Ins. by the Constitution (Forth-second Amendment) Act, 1975, s.57 (w.e.f. 31.1.1977)

Source: Rao and Singh (2005) 
PLEASE DO NOT QUOTE OR CITE WITHOUT PERMISSION

Table 6: Composition of Central Transfers to States (Rs. Billion, Percentages)

\begin{tabular}{|c|c|c|c|c|c|c|c|c|}
\hline \multirow[t]{2}{*}{$\begin{array}{c}\text { Plan Periods } \\
\text { / Years }\end{array}$} & \multicolumn{3}{|c|}{$\begin{array}{c}\text { Finance Commission } \\
\text { Transfers }\end{array}$} & \multicolumn{3}{|c|}{ Plan Grants } & \multirow[t]{2}{*}{$\begin{array}{l}\text { Other } \\
\text { Grants }\end{array}$} & \multirow[t]{2}{*}{ Total } \\
\hline & $\begin{array}{c}\text { Tax } \\
\text { Devolution }\end{array}$ & Grants & Total & $\begin{array}{l}\text { State Plan } \\
\text { Schemes }\end{array}$ & $\begin{array}{l}\text { Central } \\
\text { Schemes }\end{array}$ & Total & & \\
\hline $\begin{array}{l}\text { Fourth Plan } \\
(1969-74)\end{array}$ & $\begin{array}{c}45.60 \\
(54.35)\end{array}$ & $\begin{array}{c}8.60 \\
(10.25)\end{array}$ & $\begin{array}{c}54.20 \\
(64.60)\end{array}$ & $\begin{array}{c}10.80 \\
(12.87)\end{array}$ & $\begin{array}{c}9.70 \\
(11.56)\end{array}$ & $\begin{array}{c}20.50 \\
(24.43)\end{array}$ & $\begin{array}{c}9.30 \\
(11.08)\end{array}$ & $\begin{array}{c}83.90 \\
(100.00)\end{array}$ \\
\hline $\begin{array}{l}\text { Fifth Plan } \\
(1974-79)\end{array}$ & $\begin{array}{c}82.70 \\
(50.21)\end{array}$ & $\begin{array}{c}28.20 \\
(17.12)\end{array}$ & $\begin{array}{l}110.90 \\
(67.33)\end{array}$ & $\begin{array}{c}29.10 \\
(17.67)\end{array}$ & $\begin{array}{c}19.30 \\
(11.72)\end{array}$ & $\begin{array}{c}48.40 \\
(29.39)\end{array}$ & $\begin{array}{c}5.40 \\
(3.28)\end{array}$ & $\begin{array}{c}164.70 \\
(100.00)\end{array}$ \\
\hline $\begin{array}{l}\text { Sixth Plan } \\
(1980-85)\end{array}$ & $\begin{array}{l}237.30 \\
(56.97)\end{array}$ & $\begin{array}{l}21.40 \\
(5.14)\end{array}$ & $\begin{array}{l}258.70 \\
(62.11)\end{array}$ & $\begin{array}{c}73.80 \\
(17.72)\end{array}$ & $\begin{array}{c}69.00 \\
(16.57)\end{array}$ & $\begin{array}{l}142.80 \\
(34.29)\end{array}$ & $\begin{array}{l}15.10 \\
(3.63)\end{array}$ & $\begin{array}{c}416.50 \\
(100.00)\end{array}$ \\
\hline $\begin{array}{l}\text { Seventh Plan } \\
(1985-90)\end{array}$ & $\begin{array}{l}494.60 \\
(54.17)\end{array}$ & $\begin{array}{l}62.70 \\
(6.87)\end{array}$ & $\begin{array}{l}557.40 \\
(61.04)\end{array}$ & $\begin{array}{l}155.20 \\
(17.00)\end{array}$ & $\begin{array}{l}165.10 \\
(18.08)\end{array}$ & $\begin{array}{l}320.30 \\
(35.08)\end{array}$ & $\begin{array}{l}35.20 \\
(3.85)\end{array}$ & $\begin{array}{c}913.10 \\
(100.00)\end{array}$ \\
\hline $\begin{array}{l}\text { Annual Plan } \\
\text { 1991-92 }\end{array}$ & $\begin{array}{r}172.00 \\
(52.22)\end{array}$ & $\begin{array}{c}34.50 \\
(10.47)\end{array}$ & $\begin{array}{l}206.40 \\
(62.66)\end{array}$ & $\begin{array}{c}57.20 \\
(17.36)\end{array}$ & $\begin{array}{c}55.40 \\
(16.82)\end{array}$ & $\begin{array}{l}112.50 \\
(34.15)\end{array}$ & $\begin{array}{l}10.20 \\
(3.10)\end{array}$ & $\begin{array}{c}329.40 \\
(100.00)\end{array}$ \\
\hline $\begin{array}{l}\text { Eighth Plan } \\
(1992-97)\end{array}$ & $\begin{array}{l}1318.50 \\
(55.56)\end{array}$ & $\begin{array}{l}147.20 \\
(6.20)\end{array}$ & $\begin{array}{l}1465.70 \\
(61.76)\end{array}$ & $\begin{array}{l}483.40 \\
(20.37)\end{array}$ & $\begin{array}{l}364.70 \\
(15.37)\end{array}$ & $\begin{array}{l}848.40 \\
(35.75)\end{array}$ & $\begin{array}{l}58.40 \\
(2.46)\end{array}$ & $\begin{array}{l}2373.10 \\
(100.00)\end{array}$ \\
\hline $1997-98$ & $\begin{array}{l}404.11 \\
(62.52)\end{array}$ & $\begin{array}{l}16.80 \\
(2.60)\end{array}$ & $\begin{array}{l}420.91 \\
(65.12)\end{array}$ & $\begin{array}{l}120.08 \\
(18.58)\end{array}$ & $\begin{array}{c}67.56 \\
(10.45)\end{array}$ & $\begin{array}{l}187.64 \\
(29.03)\end{array}$ & $\begin{array}{l}37.80 \\
(5.85)\end{array}$ & $\begin{array}{c}646.35 \\
(100.00)\end{array}$ \\
\hline $1998-99$ & $\begin{array}{l}394.20 \\
(62.29)\end{array}$ & $\begin{array}{l}14.20 \\
(2.24)\end{array}$ & $\begin{array}{l}408.40 \\
(64.54)\end{array}$ & $\begin{array}{l}132.70 \\
(20.97)\end{array}$ & $\begin{array}{c}71.10 \\
(11.24)\end{array}$ & $\begin{array}{l}203.80 \\
(32.21)\end{array}$ & $\begin{array}{l}20.60 \\
(3.26)\end{array}$ & $\begin{array}{c}632.80 \\
(100.00)\end{array}$ \\
\hline 1999-00 & $\begin{array}{l}441.21 \\
(59.03)\end{array}$ & $\begin{array}{l}19.88 \\
(2.66)\end{array}$ & $\begin{array}{l}461.09 \\
(61.69)\end{array}$ & $\begin{array}{l}163.16 \\
(21.83)\end{array}$ & $\begin{array}{c}82.03 \\
(10.98)\end{array}$ & $\begin{array}{l}245.19 \\
(32.80)\end{array}$ & $\begin{array}{l}41.14 \\
(5.50)\end{array}$ & $\begin{array}{c}747.42 \\
(100.00)\end{array}$ \\
\hline 2000-01 RE & $\begin{array}{l}518.27 \\
(52.28)\end{array}$ & $\begin{array}{c}121.69 \\
(12.28)\end{array}$ & $\begin{array}{l}639.96 \\
(64.56)\end{array}$ & $\begin{array}{l}157.59 \\
(15.90)\end{array}$ & $\begin{array}{c}136.76 \\
(13.80)\end{array}$ & $\begin{array}{l}294.35 \\
(29.69)\end{array}$ & $\begin{array}{l}56.99 \\
(5.75)\end{array}$ & $\begin{array}{c}991.30 \\
(100.00)\end{array}$ \\
\hline 2001-02 BE & $\begin{array}{c}603.5 \\
(55.41)\end{array}$ & $\begin{array}{l}95.34 \\
(8.75)\end{array}$ & $\begin{array}{l}698.84 \\
(64.17)\end{array}$ & $\begin{array}{l}190.67 \\
(17.51)\end{array}$ & $\begin{array}{l}152.52 \\
(14.00)\end{array}$ & $\begin{array}{l}343.19 \\
(31.51)\end{array}$ & $\begin{array}{l}47.04 \\
(4.32)\end{array}$ & $\begin{array}{l}1089.07 \\
(100.00)\end{array}$ \\
\hline
\end{tabular}

Notes: RE: Revised Estimates, BE: Budget Estimates

Source: Rao and Singh (2005) 


\section{Table 7: Criteria and Relative Weights for Tax Sharing}

\begin{tabular}{lcc}
\hline Criterion & $\begin{array}{c}\text { Weight (\%) } \\
\text { 11th FC }\end{array}$ & $\begin{array}{c}\text { Weight (\%) } \\
\text { 12th FC }\end{array}$ \\
\hline 1. Population (1971 Census) & 10 & 25 \\
2. Income (Distance Method)* & 62.5 & 50 \\
3. Area & 7.5 & 10 \\
4. Index of Infrastructure & 7.5 & 0 \\
5. Tax Effort** & 5.0 & 7.5 \\
6. Fiscal Discipline*** & 7.5 & 7.5 \\
\hline
\end{tabular}

Notes: *The distance method is given by: $\left(\mathrm{Y}_{\mathrm{h}}-\mathrm{Y}_{\mathrm{i}}\right) \mathrm{P}_{\mathrm{i}} / \Sigma\left(\mathrm{Y}_{\mathrm{h}}-\mathrm{Y}_{\mathrm{i}}\right) \mathrm{P}_{\mathrm{i}}$ where, where $\mathrm{Y}_{\mathrm{i}}$ and $\mathrm{Y}_{\mathrm{h}}$ represent per capita SDP of the $\mathrm{i}^{\text {th }}$ and the average of the three highest income states respectively and $\mathrm{P}_{\mathrm{i}}$ is the population of the $\mathrm{i}^{\text {th }}$ state, using 1971 figures. For the three highest income states, a notional distance is assigned.

** Tax Effort $\eta$ is estimated as $\eta=\left(T_{i} / Y_{i}\right) / \sqrt{ }\left(1 / Y_{i}\right)$ where, $T_{i}$ is the per capita tax revenue collected by the $\mathrm{i}^{\text {th }}$ state and $\mathrm{Y}_{\mathrm{i}}$ is the per capita State domestic product of the $\mathrm{i}^{\text {th }}$ state.

*** Estimated as the improvement in the ratio of own revenue of a state to its revenue expenditures divided by a similar ratio for all States averaged for the period $1966-99$ over $1991-1993\left(11^{\text {th }}\right.$ FC years used for illustration).

Source: Rao and Singh (2005), Twelfth Finance Commission Report (Twelfth Finance Commission, 2004) 
Table 8: Planning Commission Formula for Distributing State Plan Assistance

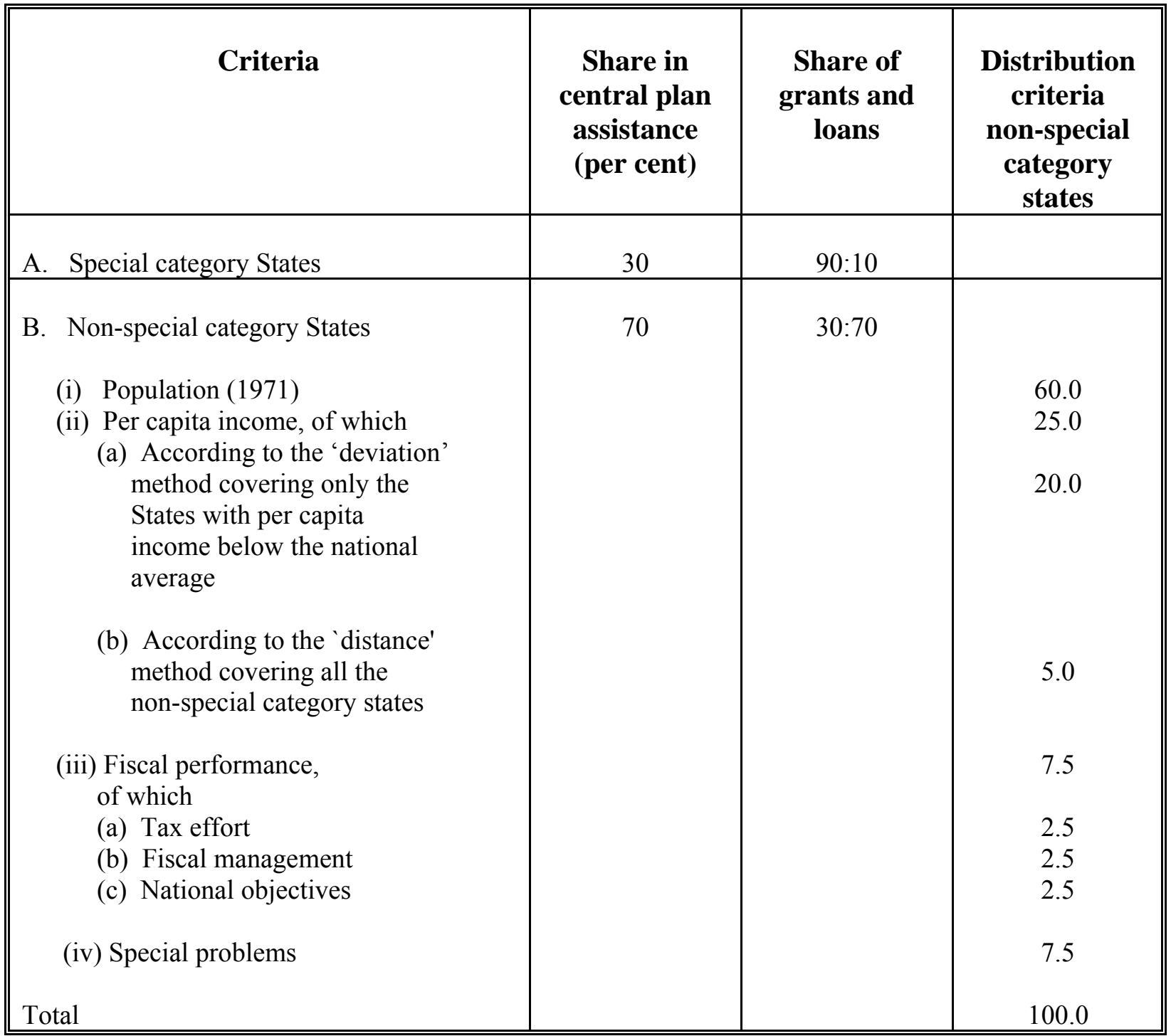

Notes: 1. The formula is as revised in December, 1991; 2. Fiscal management is assessed as the difference between States' own total plan resources estimated at the time of finalizing annual plan and their actual performance, considering latest five years; 3 . Under the criterion of the performance in respect of certain programs of national priorities the approved formula covers four objectives, viz. (i) population control, (ii) elimination of illiteracy, (iii) on-time completion of externally aided projects, and (iv) success in land reforms.

Source: Rao and Singh (2005) 
Table 9: State-Local Revenues, Percentage Composition

\begin{tabular}{lccrrr}
\hline Revenue Source & $\mathbf{1 9 9 8 - 9 9}$ & $\mathbf{1 9 9 9 - 0 0}$ & $\mathbf{2 0 0 0 - 0 1}$ & $\mathbf{2 0 0 1 - 0 2}$ & $\mathbf{2 0 0 2 - 0 3}$ \\
\hline & Rural Governments & & & \\
Own Tax & 3.64 & 3.04 & 3.24 & 3.61 & 3.87 \\
Own Non-Tax & 3.07 & 2.95 & 2.86 & 2.77 & 2.98 \\
Own Revenue & 6.71 & 5.99 & 6.10 & 6.38 & 6.84 \\
Assignment + Devolution & 30.20 & 29.23 & 28.10 & 27.46 & 27.69 \\
Grants-in-Aid & 56.34 & 58.92 & 57.76 & 58.85 & 58.95 \\
Others & 6.75 & 5.85 & 8.04 & 7.32 & 6.52 \\
Total Other Revenue & 93.29 & 94.01 & 93.90 & 93.62 & 93.16 \\
Total Revenue & 100.00 & 100.00 & 100.00 & 100.00 & 100.00 \\
& Urban Governments & & & \\
Own Tax & 41.30 & 39.10 & 38.53 & 38.85 & 39.23 \\
Own Non-Tax & 18.39 & 16.92 & 18.13 & 18.97 & 19.20 \\
Own Revenue & 59.69 & 56.02 & 56.65 & 57.83 & 58.43 \\
Assignment + Devolution & 19.18 & 20.09 & 20.45 & 18.12 & 17.69 \\
Grants-in-Aid & 15.70 & 17.09 & 15.36 & 17.64 & 16.48 \\
Others & 5.43 & 6.80 & 7.54 & 6.42 & 7.39 \\
Total Other Revenue & 40.31 & 43.98 & 43.35 & 42.17 & 41.57 \\
Total Revenue & 100.00 & 100.00 & 100.00 & 100.00 & 100.00 \\
\hline
\end{tabular}

Source: Constructed from Finance Commission (2004), Annexures 8.8 and 8.9) 
PLEASE DO NOT QUOTE OR CITE WITHOUT PERMISSION

\section{Table 10: Finance Commission Formula for Local Devolution}

\begin{tabular}{lcc}
\hline Criterion & $\begin{array}{c}\text { Weight (\%) } \\
\text { 11th FC }\end{array}$ & $\begin{array}{c}\text { Weight (\%) } \\
\text { 12th FC }\end{array}$ \\
\hline 1. Population & 40 & 40 \\
2. Distance from Highest Per Capita Income & 20 & 20 \\
3. Geographical Area & 10 & 10 \\
4. Index of Decentralization & 20 & - \\
5. Revenue Effort & 10 & 20 \\
$\quad$ (a) with respect to state's own revenue & \multicolumn{2}{c}{10} \\
$\quad$ (b) with respect to GSDP & - & 10 \\
6. Index of Deprivation & \multicolumn{2}{c}{10} \\
\hline
\end{tabular}

Source: Finance Commission (2004, Chapter 8) 
PLEASE DO NOT QUOTE OR CITE WITHOUT PERMISSION

Table 11: Central and State Fiscal Deficits (Percent of GDP)

\begin{tabular}{lccccc}
\hline Year & Center & States & \multicolumn{3}{c}{ Consolidated } \\
\hline $1990-91$ & & & Total & Revenue & Primary \\
$1991-92$ & 6.6 & 3.3 & 9.4 & 4.2 & 5.0 \\
$1992-93$ & 4.7 & 2.9 & 7.0 & 3.4 & 2.3 \\
$1993-94$ & 4.8 & 2.8 & 7.0 & 3.2 & 2.1 \\
$1994-95$ & 6.4 & 2.4 & 8.3 & 4.3 & 3.3 \\
$1995-96$ & 4.7 & 2.7 & 7.1 & 3.7 & 1.9 \\
$1996-97$ & 4.2 & 2.6 & 6.5 & 3.2 & 1.6 \\
$1997-98$ & 4.1 & 2.7 & 6.4 & 3.6 & 1.3 \\
$1998-99$ & 4.8 & 2.9 & 7.3 & 4.1 & 2.1 \\
$1999-00$ & 5.1 & 4.2 & 9.0 & 6.4 & 3.7 \\
$2000-01$ & 5.4 & 4.6 & 9.6 & 6.3 & 3.9 \\
$2001-02$ & 5.7 & 4.3 & 9.8 & 6.6 & 4.0 \\
$2002-03$ & 6.1 & 4.2 & 9.9 & 6.9 & 3.7 \\
$2003-04$ & 5.9 & 4.7 & 9.6 & 6.7 & 3.1 \\
$2004-05(\mathrm{RE})^{*}$ & 4.5 & 4.4 & 8.5 & 5.8 & 2.1 \\
$2005-06(\mathrm{BE})^{* *}$ & 4.0 & 4.0 & 8.4 & 4.1 & 2.3 \\
$2006-07(\mathrm{BE})$ & 3.8 & 3.1 & 7.7 & 3.4 & 1.8 \\
\hline
\end{tabular}

Sources: RBI Annual Reports (RBI, 2001, 2002, 2003, 2005), RBI Bulletin (RBI, 2006a).

Notes: RE: revenue estimate; BE: budget estimate; * Center's figure is actual; ** Center's figure is RE. The consolidated deficit indicators net out the inter-governmental transactions between the Center and States, and do not equal to the sum of the deficits of the Center and the States. 1990s figures for the Center exclude small savings allocated to the States, to give consistency across the accounting change related to the treatment of national small savings. The 2005-06 figures are given as reported, but appear to have an inconsistency, since the consolidated figure exceeds the center and state sum. n.a. - not available 
PLEASE DO NOT QUOTE OR CITE WITHOUT PERMISSION

Table 12: General Government Debt (percent of GDP)

\begin{tabular}{lc}
\hline \multicolumn{1}{c}{ Year } & Debt \\
\hline $1990-91$ & 64.4 \\
$1995-96$ & 61.2 \\
$2000-01$ & 70.4 \\
$2001-02$ & 75.8 \\
$2002-03$ & 80.0 \\
$2003-04$ & 81.1 \\
$2004-05(\mathrm{RE})$ & 82.0 \\
$2005-06(\mathrm{BE})$ & 81.3 \\
\hline
\end{tabular}

Source: RBI (2005) 
Table 13: Trends in Revenue and Expenditure Components, All States (\% of GDP)

\begin{tabular}{c|cccc|ccc}
\hline Period & $\begin{array}{c}\text { Own Tax } \\
\text { Revenues }\end{array}$ & $\begin{array}{c}\text { Own } \\
\text { Non-Tax } \\
\text { Revenues }\end{array}$ & $\begin{array}{c}\text { Finance } \\
\text { Commission } \\
\text { Transfers }\end{array}$ & $\begin{array}{c}\text { Non-Finance } \\
\text { Commission } \\
\text { Transfers }\end{array}$ & $\begin{array}{c}\text { Revenue } \\
\text { Expenditures }\end{array}$ & $\begin{array}{c}\text { Interest } \\
\text { Payments }\end{array}$ & Pensions \\
\hline $\mathbf{1 9 9 3 - 9 6}$ & 5.27 & 1.55 & 2.94 & 1.62 & 12.00 & 1.86 & 0.63 \\
$\mathbf{2 0 0 0 - 0 3}$ & 5.44 & 1.26 & 2.88 & 1.23 & 13.34 & 2.65 & 1.25 \\
Change & 0.17 & -0.29 & -0.05 & -0.39 & 1.34 & 0.79 & 0.62 \\
\hline
\end{tabular}

Source: Twelfth Finance Commission Report (Finance Commission, 2004) 
Table 14: Comparative Fiscal Performance, Major States (\% of GSDP)

\begin{tabular}{lllllll}
\hline & $\begin{array}{l}\text { Revenue } \\
\text { Deficit, } \\
\text { 2000-03 } \\
\text { (Rank) }\end{array}$ & $\begin{array}{l}\text { Change in } \\
\text { Revenue } \\
\text { Deficit, 1993- } \\
\text { 96 to 2000-03 } \\
\text { (Rank) }\end{array}$ & $\begin{array}{l}\text { Fiscal } \\
\text { Deficit, } \\
\text { 2000-03 } \\
\text { (Rank) }\end{array}$ & $\begin{array}{l}\text { Change in } \\
\text { Fiscal } \\
\text { Deficit, 1993- } \\
\mathbf{9 6} \text { to 2000-03 } \\
\text { (Rank) }\end{array}$ & $\begin{array}{l}\text { Debt, } \\
\text { 2000-03 } \\
\text { (Rank) }\end{array}$ & $\begin{array}{l}\text { Fiscal } \\
\text { Deficit, } \\
\text { 2004-05 } \\
\text { (Rank) }\end{array}$ \\
\hline Andhra Pradesh & $-2.03(13)$ & $-1.51(11)$ & $-4.57(9)$ & $-1.41(13)$ & $29.93(11)$ & $-3.4(12)$ \\
Bihar & $-1.87(14)$ & $-0.04(15)$ & $-4.52(10)$ & $-1.67(10)$ & $44.35(5)$ & $-5.6^{*}(4)$ \\
Goa & $-2.44(10)$ & $-3.89(3)$ & $-4.68(6)$ & $-2.38(4)$ & $33.54(9)$ & $-3.9(11)$ \\
Gujarat & $-4.66(3)$ & $-4.75(1)$ & $-5.74(5)$ & $-3.93(2)$ & $37.92(7)$ & $-6.3(2)$ \\
Haryana & $-1.32(15)$ & $-0.56(14)$ & $-3.69(15)$ & $-1.19(14)$ & $28.02(12)$ & $-1.3(15)$ \\
Karnataka & $-2.21(11)$ & $-2.15(9)$ & $-4.37(11)$ & $-1.65(11)$ & $27.27(13)$ & $-2.7(14)$ \\
Kerala & $-4.17(5)$ & $-2.99(5)$ & $-5.13(6)$ & $-1.81(6)$ & $37.58(8)$ & $-5.3(8)$ \\
Madhya Pradesh & $-2.05(12)$ & $-1.44(12)$ & $-3.94(13)$ & $-1.78(7)$ & $30.42(10)$ & $-6.3 *(2)$ \\
Maharashtra & $-3.09(7)$ & $-3.00(4)$ & $-4.12(12)$ & $-1.96(5)$ & $27.11(14)$ & $-5.2(9)$ \\
Orissa & $-4.91(2)$ & $-2.91(6)$ & $-7.84(1)$ & $-3.21(3)$ & $63.68(1)$ & $-5.6(4)$ \\
Punjab & $-4.53(4)$ & $-2.66(8)$ & $-6.14(3)$ & $-1.77(8)$ & $46.66(3)$ & $-5.2(9)$ \\
Rajasthan & $-3.87(6)$ & $-2.78(7)$ & $-6.05(4)$ & $-1.54(12)$ & $44.88(4)$ & $-6.5(1)$ \\
Tamil Nadu & $-2.50(9)$ & $-1.78(10)$ & $-3.75(14)$ & $-1.77(8)$ & $26.16(15)$ & $-2.9(13)$ \\
Uttar Pradesh & $-2.98(8)$ & $-1.21(13)$ & $-5.07(7)$ & $-1.03(15)$ & $46.94(2)$ & $-5.6^{*}(4)$ \\
West Bengal & $-5.47(1)$ & $-3.95(2)$ & $-7.31(2)$ & $-4.13(1)$ & $42.73(6)$ & $-5.4(7)$ \\
\hline
\end{tabular}

Source: Twelfth Finance Commission Report (Finance Commission, 2004) and RBI (2006b)

* These states' figures exclude those for the split-off states of Jharkhand (-8.1\%), Chhattisgarh (-5.6\%) and Uttaranchal (-13.8\%) 
Table 15: Comparative Revenues and Expenditures, Major States (\% of GSDP)

\begin{tabular}{lcccc}
\hline & $\begin{array}{l}\text { Own Tax } \\
\text { Revenue, } \\
\text { 2000-03 (Rank) }\end{array}$ & $\begin{array}{l}\text { Change in Own } \\
\text { Tax Revenue, } \\
\text { 1993-96 to 2000- } \\
\text { 03 (Rank) }\end{array}$ & $\begin{array}{l}\text { Revenue } \\
\text { Expenditure, } \\
\text { 2000-03 (Rank) }\end{array}$ & $\begin{array}{l}\text { Change in } \\
\text { Revenue } \\
\text { Expenditure, } \\
\text { 1993-96 to } \\
\text { 2000-03 (Rank) }\end{array}$ \\
\hline Andhra Pradesh & $7.30(9)$ & $1.40(12)$ & $15.56(10)$ & $2.08(9)$ \\
Bihar & $4.46(2)$ & $0.75(7)$ & $18.11(3)$ & $1.60(11)$ \\
Goa & $6.46(6)$ & $-1.45(1)$ & $17.25(5)$ & $0.13(15)$ \\
Gujarat & $7.71(10)$ & $0.20(5)$ & $18.37(2)$ & $5.85(1)$ \\
Haryana & $8.30(13)$ & $1.09(9)$ & $13.45(15)$ & $0.39(14)$ \\
Karnataka & $8.33(14)$ & $-0.19(4)$ & $15.33(11)$ & $1.36(12)$ \\
Kerala & $8.11(12)$ & $-0.34(3)$ & $16.11(8)$ & $1.18(13)$ \\
Madhya Pradesh & $6.45(5)$ & $1.53(13)$ & $16.74(7)$ & $3.45(3)$ \\
Maharashtra & $7.76(11)$ & $1.12(10)$ & $14.10(14)$ & $3.42(4)$ \\
Orissa & $5.81(3)$ & $1.87(14)$ & $22.22(1)$ & $5.74(2)$ \\
Punjab & $7.13(8)$ & $1.87(14)$ & $15.33(11)$ & $2.59(7)$ \\
Rajasthan & $6.48(7)$ & $0.25(6)$ & $18.06(4)$ & $2.63(6)$ \\
Tamil Nadu & $9.00(15)$ & $0.98(8)$ & $15.60(9)$ & $1.66(10)$ \\
Uttar Pradesh & $5.88(4)$ & $1.12(10)$ & $16.78(6)$ & $2.50(8)$ \\
West Bengal & $4.26(1)$ & $-1.20(2)$ & $15.02(13)$ & $3.23(5)$ \\
\hline
\end{tabular}

Source: Twelfth Finance Commission Report (Finance Commission, 2004) 
Table 16: Summary of Fiscal Situation of Local Governments (Rs. 10 million)

\begin{tabular}{|c|c|c|c|c|c|}
\hline & 1998-99 & 1999-00 & 2000-01 & 2001-02 & 2002-03 \\
\hline \multicolumn{6}{|c|}{ Rural Governments } \\
\hline Total Revenue & 17295.68 & 22264.13 & 23244.36 & 22470.07 & 24010.52 \\
\hline \multicolumn{6}{|l|}{ Expenditure } \\
\hline Revenue Expenditure & 13031.47 & 15889.15 & 18131.61 & 18177.17 & 17739.97 \\
\hline Capital Expenditure & 5275.41 & 5803.97 & 5928.53 & 5764.02 & 6546.32 \\
\hline Total Expenditure & 18306.89 & 21693.12 & 24060.14 & 23941.19 & 24286.29 \\
\hline \multicolumn{6}{|c|}{ Urban Governments } \\
\hline Total Revenue & 11514.64 & 13172.96 & 14581.04 & 15149.20 & 12596.50 \\
\hline \multicolumn{6}{|l|}{ Expenditure } \\
\hline Revenue Expenditure & 9059.47 & 10690.30 & 11665.88 & 12204.78 & 10671.63 \\
\hline Capital Expenditure & 2975.47 & 3761.36 & 4077.17 & 3709.51 & 3325.40 \\
\hline Total Expenditure & 12034.95 & 14451.67 & 15743.05 & 15914.29 & 13997.02 \\
\hline
\end{tabular}

Source: Twelfth Finance Commission Report (Finance Commission, 2004) 
Table 17: State Level Human Development Indices

\begin{tabular}{lcrcrcr}
\hline State & $\mathbf{1 9 8 1}$ & $\mathbf{1 9 8 1}$ & $\mathbf{1 9 9 1}$ & $\mathbf{1 9 9 1}$ & $\mathbf{2 0 0 1}$ & $\mathbf{2 0 0 1}$ \\
\hline & Value & Rank & Value & Rank & Value & Rank \\
Andhra Pradesh & 0.298 & 9 & 0.377 & 9 & 0.416 & 10 \\
Bihar & 0.237 & 14 & 0.308 & 14 & 0.367 & 14 \\
Gujarat & 0.360 & 4 & 0.431 & 6 & 0.479 & 6 \\
Haryana & 0.360 & 5 & 0.443 & 5 & 0.509 & 5 \\
Karnataka & 0.346 & 6 & 0.412 & 7 & 0.478 & 7 \\
Kerala & 0.500 & 1 & 0.591 & 1 & 0.638 & 1 \\
Madhya Pradesh & 0.245 & 13 & 0.328 & 12 & 0.394 & 12 \\
Maharashtra & 0.363 & 3 & 0.452 & 4 & 0.523 & 4 \\
Orissa & 0.267 & 10 & 0.345 & 11 & 0.404 & 11 \\
Punjab & 0.411 & 2 & 0.475 & 2 & 0.537 & 2 \\
Rajasthan & 0.256 & 11 & 0.347 & 10 & 0.424 & 9 \\
Tamil Nadu & 0.343 & 7 & 0.466 & 3 & 0.531 & 3 \\
Uttar Pradesh & 0.255 & 12 & 0.314 & 13 & 0.388 & 13 \\
West Bengal & 0.305 & 8 & 0.404 & 8 & 0.472 & 8 \\
All India & 0.302 & & 0.381 & & 0.472 & \\
& & & & & & \\
Unweighted average & 0.325 & & 0.407 & & 0.469 & \\
Standard deviation & 0.071 & & 0.075 & & 0.072 & \\
Coefficient of variation & 0.219 & & 0.185 & & 0.155 & \\
\hline
\end{tabular}

Sources: Planning Commission (2002) and Singh and Srinivasan (2005). 